NBER WORKING PAPER SERIES

\title{
WHAT EXPLAINS THE GENDER GAP IN WEALTH? EVIDENCE FROM ADMINISTRATIVE DATA
}

\author{
Jaanika Meriküll \\ Merike Kukk \\ Tairi Rõõm \\ Working Paper 26920 \\ http://www.nber.org/papers/w26920 \\ NATIONAL BUREAU OF ECONOMIC RESEARCH \\ 1050 Massachusetts Avenue \\ Cambridge, MA 02138 \\ April 2020
}

The authors acknowledge financial support from the project InWeGe, financed by European Union's Rights, Equality and Citizenship Program (2014-2020), No 820778. The content of this working paper represents the views of the authors only and is their sole responsibility. The European Commission does not accept any responsibility for use that may be made of the information it contains. The authors would like to thank the participants at Bank of Estonia and Tallinn University of Technology research seminars, at the annual conference of Estonian Economic Association and at the 2nd Baltic Economic Conference for their insightful comments. The views expressed herein are those of the authors and do not necessarily reflect the views of the National Bureau of Economic Research.

NBER working papers are circulated for discussion and comment purposes. They have not been peer-reviewed or been subject to the review by the NBER Board of Directors that accompanies official NBER publications.

(C) 2020 by Jaanika Meriküll, Merike Kukk, and Tairi Rõõm. All rights reserved. Short sections of text, not to exceed two paragraphs, may be quoted without explicit permission provided that full credit, including $\odot$ notice, is given to the source. 
What Explains the Gender Gap in Wealth? Evidence from Administrative Data Jaanika Meriküll, Merike Kukk, and Tairi Rõõm

NBER Working Paper No. 26920

April 2020

JEL No. D31,J16,J71

\begin{abstract}
$\underline{\text { ABSTRACT }}$
This paper studies the gender gap in net wealth. We use administrative data on wealth that are linked to the Estonian Household Finance and Consumption Survey, which provides individuallevel wealth data for all household types. We find that the unconditional gender gap in mean wealth is $45 \%$ and that it is caused by large wealth disparities in the upper end of the wealth distribution. The structure of assets owned by men is more diversified than that for women. Men own more business assets and vehicles, while women own more deposits. The gender gaps in these asset components cannot be explained by observable characteristics. For partner-headed households the raw gender gaps across deciles are mostly in favour of men, and more strongly so for married couples, indicating that resources are not entirely pooled within households. For single-member households the raw gaps across quantiles are partially in favour of women. Accounting for observable characteristics renders the unexplained parts of the gaps mostly insignificant for all household types.
\end{abstract}

Jaanika Meriküll

Bank of Estonia

Estonia pst 13

15095 Tallinn

Estonia

and Tartu University

jaanika.merkyll@eestipank.ee

Merike Kukk

Tallinn University of Technology

Akadeemia tee 3-478

Tallinn 12618

Estonia

and Bank of Estonia

merike.kukk@taltech.ee
Tairi Rõõm

Bank of Estonia

Estonia pst 13

15095 Tallinn

Estonia

and Tallinn University of Technology

tairi.room@eestipank.ee 


\section{Introduction}

The gender gaps in various forms of income, such as wages or pensions, have been extensively studied in the academic literature, but there have been substantially fewer studies that have focused on the gender differences in wealth. The aim of this paper is to help filling this research gap. Wealth is an important indicator of welfare and measuring wealth inequalities is relevant both at the level of the population as a whole and within households. While income gaps show current inequality, wealth gaps depict inequality that has accumulated over a longer time span.

The main reason why only a few existing papers have studied gender wealth gaps is that individual-level wealth data are rarely available. Wealth surveys usually collect data at the household level, with only a few exceptions. Consequently, many studies on this topic are based on household-level data, which means that they either analyse the gender wealth gap only among households with one member (e.g. Schmidt and Sevak (2006), Schneebaum et al. (2018), and Ravazzini and Chesters (2018)) or impute the allocation of wealth within larger households on the basis of the data from single-member households (for an overview of the methods for this see Bonthieux and Meurs (2015)). Both of these approaches have disadvantages, because the raw (or unconditional) gender wealth gaps vary over different household types. They are larger for couple-headed households and smaller and often statistically insignificant for singlemember households (Sierminska et al. (2010), Bonnet et al. (2013)). This means that the gender gaps which are estimated on the basis of single-member households are not generalisable to the whole population.

Relatively few papers on the gender wealth gap use individual-level wealth data and cover all types of households. ${ }^{1}$ All of these studies use survey data collected by household interviews. The present paper differs from the earlier papers by employing a different data source. We use a novel dataset from Estonia that derives individual-level wealth data from various administrative sources and links them with the Estonian Household Finance and Consumption Survey data from 2013. The main advantage of this combined dataset is that it covers register-based wealth items at the individual level together with other household characteristics from the survey. The administrative data are superior in quality to the survey data, but administrative datafiles often give no information on household structure. The combined dataset used in this article overcomes this problem.

The present paper aims to contribute to the literature in several ways. First, we decompose the gender wealth gaps into explained and unexplained parts and explore the distribution of unconditional and conditional gender wealth gaps for different components of net wealth. This lets us evaluate which of the different types of assets and liabilities contribute more to the gender gap in net wealth. Differences in the wealth composition of men and women have not been explored at such a detailed level as we can do with the current dataset. None of the earlier studies have estimated conditional gender wealth gaps for various wealth items, i.e. there is no information on whether the differences in the structure of assets for men and for women can be explained by observable characteristics such as differences in income.

\footnotetext{
${ }^{1}$ To the best of our knowledge, individual-level wealth data are used in the following articles: Sierminska et al. (2010) and Grabka et al (2015) on German data, Bonnet et al. (2013) on French data, D'Allessio (2018) on Italian data, and Doss et al. (2014) on data for some developing countries.
} 
Second, we conduct a comprehensive analysis of gender gaps in net wealth over different household types. We compare the distributions of unconditional and conditional wealth gaps between men and women among single-member households, couple-headed households and other types of households. Earlier studies using individual-level wealth data have assessed the raw gaps for single-member and couple-headed households but have not conducted the decomposition and estimated the unconditional and conditional gaps separately for different household types (Sierminska et al. (2010), Bonnet et al. (2013)).

Third, we base our analysis on data from a different source. While earlier studies have been based on survey data, we use data derived from administrative files. It can be expected that administrative data are much less prone to measurement error than survey data are. Various sources of measurement error in survey data have been discussed e.g. by Riphahn and Serfling (2005). When measurement errors are caused by systemic under- or over-reporting of various components of net wealth then they may lead to biased estimates of gender wealth gaps. There is evidence that women tend to under- and men overestimate the value of assets they own (Zagorsky (2003)). This implies that the survey-based assessments of the gender gaps in net wealth may be overestimated. Using administrative data lets us avoid the possible gender biases that are embedded in the wealth surveys.

Finally, the current paper provides novel knowledge on the gender wealth gap in Estonia, which is the country that has the largest gender wage gap in the EU (see e.g. Eurostat series sdg_05_020). If the wealth functions of men and women are similar, then disparities in income are transferred to disparities in wealth. This also provides a good background for exploring how much married couples pool their resources to accumulate assets.

Many potential sources of the gender gap in wealth have been identified in the literature. The reasons why the wealth function may be different for men and women, which would lead to differences in wealth accumulation, are discussed more thoroughly in the next section and we mention them here only briefly. First and foremost, the gender gap in wealth may arise because of income differences between the genders. It is well established that men earn more and have higher labour market participation rates than women (e.g. Blau and Kahn (2000)). This lets men accumulate more wealth than women do. Besides income differences, the gender gap can be caused by differences in consumption and saving patterns (e.g. Fisher (2010), Sunden and Surrette (1998)) or because women and men invest differently (e.g. Hinz et al (1997), Grable (2000)). Finally, men and women could inherit differently and this could contribute to wealth inequality, but studies mostly do not find that inheritance differs by gender (e.g. Edlund and Kopczuk (2009)).

The various assets that a household owns are often used by all the members of the household and provide utility for the members who are not the owners of the particular items. Even so, the distribution of wealth within a household is relevant for two main reasons. First, it affects the bargaining power of individual household members over the allocation of resources within the household. Second, the joint use of wealth is not guaranteed for the full life of both partners but only until the end of their relationship. This makes it important for both men and women to accumulate savings for unexpected income shocks and for retirement income. This has become more relevant recently as more marriages and partnerships are ending in separations and the division of assets after separation depends on the ownership of the assets. Both men and women receive wealth premiums from marriage (Lersch (2017)), while divorces create wealth losses for both former partners (Ulker (2009), Grabka et al. (2015)). 
Wealth inequality is typically much greater than income inequality (e.g. HFCN (2013)). This implies that wealth differences between the genders may also be more substantial than income differences. Equally though, assets acquired during a marriage are usually split evenly, unless a couple has a prenuptial agreement that stipulates otherwise, and this reduces gender wealth inequality within married couples. The key findings on the magnitude of the gender wealth gap are summarised by Bonthieux and Meurs (2015). Men's mean level of wealth is $45 \%$ higher than that of women in Germany (Sierminska et al. (2010)), 15\% higher in France (Bonnet et al. (2013)) and 18\% higher in Italy (D'Allessio (2018)). Findings for some developing countries indicate that the gender gap in wealth is more substantial there. Men have two to four times more gross assets than women do in Ghana and India (Doss et al. (2014)).

This paper uses the unconditional quantile regressions suggested by Firpo et al. (2009) to estimate the size of the gender gap over the distribution of net wealth. We decompose the raw gap into explained and unexplained components using an Oaxaca-Blinder decomposition based on unconditional quantile regressions. We estimate the unconditional and conditional gender wealth gaps for various assets and liabilities and for different household types. To the best of our knowledge there is no earlier study that investigates the gender wealth gaps in all these dimensions.

We find that the mean unconditional gender wealth gap is as large as $45 \%$ in Estonia. However, the gap in means originates mostly from the top tail of the wealth distribution, where men have much more wealth than women, while the gaps are statistically insignificant in lower parts of the wealth distribution. Men have more wealth in the form of self-employment business assets than women do, and the gender wealth gap is the largest for this asset class, which is the main source of the large gender wealth gap in means.

It is also found that the raw gender wealth gap is largest among partner-headed households, while it is negative (i.e. in favour of women) or statistically insignificant in single-member households. This highlights how important it is to use individual-level data that cover all household types for analysing the gender wealth gap, since assessments based purely on singlemember households can provide results that are not valid for other household types. Conditioning on observed characteristics usually renders the gaps statistically insignificant, but there are insightful exceptions. Men have more vehicles, business assets and private pension assets and women have more deposits even after controlling for observable characteristics. Surprisingly, these differences do not disappear after controlling for gender differences in risk aversion. The estimated results point to large heterogeneity in the gender wealth gap over various net wealth components and household types, confirming the need to go beyond the means and aggregates.

The paper is structured as follows: the next section discusses the wealth accumulation function and possible reasons for the gender wealth gap, Section 3 covers the data and methods, Section 4 presents the results, Section 5 discusses the results in the context of income and consumption, and the last section summarises. 


\section{The wealth accumulation function}

The total wealth $\mathrm{W}$ of an individual in period $t$ depends on their accumulated wealth, their additional savings $\mathrm{S}$ in period $t$, gifts or inheritances $\mathrm{H}$ received in period $t$, and the returns $r$ on the previously accumulated resources in period $t$. Resources can be held in different asset types with different risk and return, meaning that $W_{t-1}=\sum_{a=1}^{n} w_{\alpha, t-1}$ where $\alpha$ denotes a particular type of asset. Wealth accumulation over periods can be described as:

$$
W_{t}=\sum_{a=1}^{n}\left(1+r_{a t}\right) w_{a, t-1}+S_{t}+H_{t}
$$

and the total savings $S$ of an individual in the current period, regardless of asset types, depend on the total after-tax income $Y$ and total spending $C$ in that period:

$$
S_{t}=Y_{t}-C_{t}
$$

The accumulation of wealth can be different for men and for women because of several reasons. First, differences in wealth accumulation can result from men and women holding different portfolios of assets. The wealth composition for individuals varies widely as it depends on their risk preferences. Several studies have shown that women make more conservative investments and are in general more risk averse (e.g. Jianakopolos and Bernasek (1998), Grable (2000), Hallahan et al. (2004), Nelson (2015)). They also have lower stock market participation rates than men do (e.g. Bajtelsmit and Bernasek (1996), Hinz et al (1997), Embrey and Fox (1997)). Additionally, investment choices depend on financial literacy (van Rooij et. al. (2011)). Empirical evidence suggests that men are more financially literate than women are (e.g. Chen and Volpe (2002), Lusardi and Mitchell (2008)), which could be one reason why men have higher stock market participation rates. As a general rule, holding riskier assets results in higher long-term returns, implying that even with the same level of initial wealth and savings men are able to accumulate more wealth over time.

Differences in income are an important source of wealth inequality between men and women. Total after-tax income and spending are endogenous and depend on the individual's choices, and so saving can also vary across genders. The after-tax income of women is affected because they are more likely to have career breaks to have children, leaving them fewer years of work experience and lower wages than those of men with the same characteristics. Women are more likely to work part-time than men, which also results in them having smaller incomes. If women are paid less than men, their ability to save is lower, and consequently the gender pay gap spills directly into the wealth gap.

In addition, income differences between men and women can result from the different occupational choices they make. Male-dominated professions tend to be better paid than female-dominated professions are and occupational segregation is one of the sources of the existing gender wage gap (e.g. Dolado et. al. (2002)). Men are also more likely to become entrepreneurs and to have self-employment income than women are (Koellinger et. al. (2013)). As being an entrepreneur is a riskier occupational choice, it is generally also better rewarded.

Differences in earnings may have additional implications for the wealth composition. As credit constraints are higher for lower levels of income (HFCN (2016)), women may be denied mortgage loans more often than men are. Alesina et. al. (2013) show that women also face more stringent conditions for obtaining business credit than men do. Consequently, women are less 
able to benefit by building wealth from owning self-employment businesses or from the longterm rises in house prices that accrue from homeownership.

Additionally, the gender wealth gap in favour of men may be caused by men inheriting more than women. Empirical evidence shows that inheritances have a role in explaining the net wealth of households in a number of western European countries (Fessler et al. (2018)). However, the existing empirical evidence mostly shows for developed countries that the probability of inheriting is not dependent on gender (e.g. Edlund and Kopczuk (2009)).

There are different approaches to how individual wealth functions are linked to the household-level wealth function. Studies that focus on the within-household allocation of resources distinguish between two different household models, depending on the decisionmaking structure. According to this literature, a household can act either as a unitary unit or as a collective one. Standard microeconomic theory assumes the unitary model, where household resources are pooled and there is a single utility function and budget constraint (see e.g. Doss (1996)). The alternative, the collective model, would imply that household members have different preferences and the observed consumption, savings and investment patterns are the result of bargaining.

The unitary model has frequently been rejected in empirical studies as it has been shown that households do not exhibit full pooling of resources and that they are moving towards more individualised systems, such as partial pooling (Vogler et al. (2006), Pahl (2008)). Ashby and Burgoyne (2009) show that partial pooling is also found for savings. Studies show that the consumption of household members depends on their income shares (Bonke 2015), as women spend more on children (Lundberg et al. (1997), Phipps and Burton (1998)) and tend to save less than men (Phipps and Woolley (2008)). There is empirical evidence showing that the bargaining power of women within the family is linked to their education, income and assets (Doss (2013)). If there is a systematic difference in how men and women accumulate individual savings and if families are not pooling all their savings, it would contribute to household members having different wealth functions.

The upshot is that any systematic differences in wealth accumulation between men and women, and also any within a household, lead to a gender wealth gap. If there is a wealth gap, it is important to understand the role of each determinant in explaining the gap.

\section{Data and methods}

\subsection{Data}

This paper employs a sample of individual-level wealth data collected from administrative registers in Estonia. The administrative data are combined with the Estonian survey data from the Household Finance and Consumption Survey (HFCS) that is run by the euro area central banks. The resulting database has two unique features. First, it covers a comprehensive set of individual-level wealth items, liabilities and income types taken from various administrative registers. Second, it is merged with survey data that provide information on self-reported household structure and a rich set of control variables. Data from interviews have only been used where the information is not available in registers. The survey-based variables cover the characteristics of household structure, individual-level labour market status, tenure, 
immigration status and education. The administrative data capture well the whole wealth distribution and are free of the problems caused by item non-response.

The main purpose of constructing such a database with administrative and survey data was to validate the survey-based estimates of wealth items. The information from the survey was combined with register information for all the 2220 households and 4675 household members in the final survey sample. The collection of the survey data was harmonised with the other countries participating in the HFCS. The survey data were collected by Statistics Estonia, the national statistical institution, using computer-assisted personal interviews, and the administrative data were collected by the same institution in cooperation with the Statistics Department of the central bank of Estonia. The fieldwork for the survey was done in the second quarter of 2013 and the values of the wealth items were measured at the time of the interview. Wealthy households were oversampled to give better coverage of the richest households. This implies that our administrative data do not cover the whole population, but are available for the sample of individuals who participated in the HFCS. Sampling weights are used throughout the paper to make the sample representative of the whole population. We perform the analysis for adults and exclude children under 16 and dependent children under 25 from the sample.

Details about the HFCS survey data can be found in HFCN (2016). The sources of administrative data are described in Table 1 . The wealth items covered by the data collected from administrative sources are real estate, household vehicles, self-employment business wealth, deposits, mutual funds, bonds, stocks, private pensions, bank loans, bank overdraft debts and credit card debts. The majority of the conventional components of survey-based net wealth are covered by the administrative data. The only conventional items that are not covered are cash at home, valuables, managed accounts and private loans. These items cover only a minor fraction of the total wealth, providing $1 \%$ according to the survey data.

Table 1 shows that the participation in different types of wealth items is well captured by administrative data, as the data on the ownership of particular items is based on official ownership records in various registers or on administrative data from commercial banks. Most importantly for the purposes of this paper, the ownership of all the wealth items is defined at the individual level. The extensive coverage of wealth items lets us investigate the gender wealth gap at a detailed level for a wide range of asset types, including self-employment assets, and for liabilities. The value of financial assets and liabilities is precisely measured, while the value of real assets is estimated from transaction prices or prices asked for vehicles and real estate and from the value of equity capital in the balance sheets for self-employment businesses. This implies that the values of financial assets and liabilities can be taken as very close estimates of their true values in the administrative data, while the values of real assets may be subject to measurement error as not all the detailed features of these items can be taken into account when their market values are estimated ${ }^{2}$. However, there is no reason to believe that there are systematic biases in the estimates of real assets. The rates of participation in the various wealth

\footnotetext{
${ }^{2}$ Another caveat of our registry data concerns married couples. A wealth item with joint ownership or a joint liability is often assigned to only one spouse in a registry, while both of the spouses have a legal right to it. The assets and liabilities that are obtained during the marriage and are not inherited should be shared in equal parts by spouses. Unfortunately, registers do not always cover this correctly. We do not have any information about the duration of the marriage and the date when a particular wealth item was obtained. We split all the real estate assets and mortgages related to the assets for married couples, unless the couple has inherited it. The information about inheritances is obtained from the survey.
} 
items that are estimated using the administrative records are close to their true values for all asset types, including financial and real assets.

Table 1: The sources of administrative data used to derive the value of wealth items

\begin{tabular}{|c|c|c|}
\hline Wealth item & Item participation & Value of the item \\
\hline Real estate & $\begin{array}{l}\text { Land Register, official register of } \\
\text { ownership and the share of ownership } \\
\text { of an individual }\end{array}$ & $\begin{array}{l}\text { Estimates based on the Land Board's } \\
\text { average transaction price per } \mathrm{m}^{2} \text { for } \\
\text { different real estate types within a } \\
\text { detailed district }\end{array}$ \\
\hline Vehicles & $\begin{array}{l}\text { Vehicle Register of the Estonian Road } \\
\text { Administration, the official register of } \\
\text { ownership and the share of ownership } \\
\text { of an individual }\end{array}$ & $\begin{array}{l}\text { Estimates based on the average price } \\
\text { asked for the model and age of a } \\
\text { vehicle. Data on prices asked from a } \\
\text { private online seller of vehicles with } \\
\text { more than } 100000 \text { vehicles } \\
\text { (http://eng.auto24.ee). }\end{array}$ \\
\hline $\begin{array}{l}\text { Self-employment } \\
\text { business }\end{array}$ & $\begin{array}{l}\text { Business Register, official register of } \\
\text { ownership and the share of ownership } \\
\text { of an individual }\end{array}$ & $\begin{array}{l}\text { Value of equity capital in the balance } \\
\text { sheet of the Business Register }\end{array}$ \\
\hline Deposits & $\begin{array}{l}\text { Administrative data from commercial } \\
\text { banks about item participation at } \\
\text { individual level }\end{array}$ & $\begin{array}{l}\text { Administrative data from commercial } \\
\text { banks about the value }\end{array}$ \\
\hline $\begin{array}{l}\text { Mutual funds, bonds, } \\
\text { stocks }\end{array}$ & $\begin{array}{l}\text { Central Register of Securities, official } \\
\text { register of ownership and the share of } \\
\text { ownership at individual level }\end{array}$ & $\begin{array}{l}\text { Value in the Central Register of } \\
\text { Securities }\end{array}$ \\
\hline Private pension & $\begin{array}{l}\text { Central Register of Securities, official } \\
\text { register of ownership and the share of } \\
\text { ownership at individual level }\end{array}$ & $\begin{array}{l}\text { Value in the Central Register of } \\
\text { Securities }\end{array}$ \\
\hline $\begin{array}{l}\text { Outstanding balance of } \\
\text { loans }\end{array}$ & $\begin{array}{l}\text { Administrative data from commercial } \\
\text { banks about item participation at } \\
\text { individual level }\end{array}$ & $\begin{array}{l}\text { Administrative data from commercial } \\
\text { banks about the outstanding balance }\end{array}$ \\
\hline $\begin{array}{l}\text { Outstanding bank } \\
\text { overdraft debts and } \\
\text { credit card debts }\end{array}$ & $\begin{array}{l}\text { Administrative data from commercial } \\
\text { banks about item participation at } \\
\text { individual level }\end{array}$ & $\begin{array}{l}\text { Administrative data from commercial } \\
\text { banks about the outstanding balance }\end{array}$ \\
\hline
\end{tabular}

The administrative data share a limitation with the survey data because some households may be hiding their wealth and the true wealth cannot be computed from official sources either. The existing literature suggests that the wealthiest part of the population keeps a share of their wealth offshore and so the register data underestimate the wealth of the richest (e.g. Zucman (2014), Roine and Waldenström (2009)). This is also a problem for the survey data if individuals are consistent in their reporting to surveys and tax authorities. Roine and Waldenström (2009) demonstrate with a Swedish example that the foreign wealth not captured by administrative data can affect the top $1 \%$ of wealth shares by as much as $50 \%$. Sweden had high wealth taxes and foreign wealth has increased substantially since capital controls were removed in the 1980s. However, this limitation is not expected to be prevalent in Estonia, where wealth 
is not heavily taxed. The only taxed asset is land, which is to a large extent tax-exempt and the tax rates on land are small, so there are no strong incentives to hide assets because of taxes ${ }^{3}$.

It has also been shown that the wealth surveys do not cover the richest households well since data for the top tail of the wealth distribution are often missing, even in surveys that oversample the rich (Vermeulen (2016) and Vermeulen (2018)). The chance of missing out on very rich households is also a problem for the dataset used in the present paper, since although we use administrative data, the dataset covers households that participated in the HFCS survey and may therefore be subject to such selective unit non-response.

The joint or independent taxation of income can also affect the allocation of investment assets within households for reasons of tax avoidance (Stephens and Ward-Batts (2003)). Married couples can submit their income declarations jointly or independently in our sample country, Estonia, which may create incentives to switch some assets to the lower-income spouse. However, this incentive was likely to be very small in Estonia at the time of the survey as the tax system had very little progressivity.

Another limitation of the dataset is that we cannot disentangle inherited wealth from selfobtained wealth for individual household members as this information is not available in registers and is collected in the survey at the household level. Empirical evidence shows that inheritances have a role in explaining the net wealth of households in a number of western European countries (Fessler et al. (2018)). However, it has been shown that intergenerational transfers play only a marginal role in explaining the gender wealth gap (Sierminska et al. (2010) and Bonnet et al. (2013)). The share of inherited wealth in total wealth was also modest in Estonia according to the HFCS survey, as the average share of wealth that was inherited was $3.2 \%$.

Table 2 presents the descriptive statistics on wealth for men and women across various wealth items. The unconditional gender gap in mean net wealth is in favour of men in Estonia. Men have on average $45 \%$ more net wealth than women, the respective mean values are 51.3 thousand euros and 35.3 thousand euros. The gender gap in mean net wealth originates from the strong concentration of wealth among men, as women have more net wealth than men below the median and men have more net wealth than women at the top of the distribution. The Gini coefficient of net wealth is 0.81 for men and 0.71 for women. The individual-level wealth inequality is higher than the household-level inequality, as the Gini coefficient of net wealth is 0.76 in the individual-level data and 0.70 in the household-level data. Earlier studies have also shown that wealth inequality is higher at the individual level than at the household level (e.g. Frick et al. (2007)).

The gender wealth gap in the mean level of gross total assets is similar in magnitude to that in net wealth, but the wealth gaps differ substantially across various asset types. Men and women have quite similar mean levels of real estate and deposits, while men have more wealth in vehicles, self-employment businesses, and stocks and bonds. These unconditional regularities are similar to the ones found by the related literature (Sierminska et al. (2010), Bonnet et al. (2013), D'Allessio (2018)). As household main residence contributes most to total wealth, it seems to be an important equaliser of wealth between men and women.

\footnotetext{
${ }^{3}$ The land tax rate varies between municipalities and is in the range of $0.1 \%$ to $2.5 \%$ of the taxable value annually. The land value is set by local governments. The plots of land that belong to household main residences are tax exempt, which means that a large share of households pay no taxes on their property.
} 
Table 2: Descriptive statistics of individual-level net wealth components by gender

\begin{tabular}{|c|c|c|c|c|c|c|c|c|c|}
\hline & \multicolumn{4}{|c|}{ Men } & \multicolumn{4}{|c|}{ Women } & \multirow{2}{*}{$\begin{array}{c}\text { Men/ } \\
\text { women, } \\
\text { ratio of } \\
\text { means }\end{array}$} \\
\hline & $\begin{array}{c}\text { 10th } \\
\text { quantile }\end{array}$ & $\begin{array}{c}\text { 50th } \\
\text { quantile }\end{array}$ & $\begin{array}{c}\text { 90th } \\
\text { quantile }\end{array}$ & Mean & $\begin{array}{c}\text { 10th } \\
\text { quantile }\end{array}$ & $\begin{array}{c}\text { 50th } \\
\text { quantile }\end{array}$ & $\begin{array}{c}\text { 90th } \\
\text { quantile }\end{array}$ & Mean & \\
\hline Total assets & 4 & 20426 & 115850 & 58093 & 16 & 21817 & 94690 & 40587 & $1.43 * *$ \\
\hline Total real assets & 0 & 17293 & 108180 & 52540 & 0 & 18443 & 86031 & 36483 & $1.44 * *$ \\
\hline ... real estate & 0 & 12955 & 95641 & 36451 & 0 & 17221 & 81589 & 34391 & 1.06 \\
\hline ... vehicles & 0 & 0 & 6200 & 2155 & 0 & 0 & 1700 & 574 & $3.75^{* * *}$ \\
\hline $\begin{array}{l}\ldots \text { self-employment } \\
\text { businesses }\end{array}$ & 0 & 0 & 3541 & 13934 & 0 & 0 & 0 & 1518 & $9.18 *$ \\
\hline $\begin{array}{l}\text { Total financial } \\
\text { assets }\end{array}$ & 0 & 337 & 11852 & 5553 & 1 & 680 & 10471 & 4104 & $1.35 * * *$ \\
\hline ... deposits & 0 & 192 & 9732 & 4411 & 1 & 424 & 9654 & 3677 & $1.20 *$ \\
\hline $\begin{array}{l}\ldots \text { stocks and } \\
\text { bonds }\end{array}$ & 0 & 0 & 0 & 476 & 0 & 0 & 0 & 86 & $5.55^{*}$ \\
\hline ... private pensions & 0 & 0 & 1089 & 666 & 0 & 0 & 904 & 341 & $1.95^{* * * *}$ \\
\hline Total liabilities & 0 & 0 & 23617 & 6804 & 0 & 0 & 17997 & 5284 & $1.29 * * *$ \\
\hline ... loans & 0 & 0 & 23102 & 6593 & 0 & 0 & 17656 & 5138 & $1.28 * * *$ \\
\hline $\begin{array}{l}\text {... bank overdrafts } \\
\text { and credit card } \\
\text { debt }\end{array}$ & 0 & 0 & 624 & 211 & 0 & 0 & 497 & 146 & $1.44 * * *$ \\
\hline Net wealth & -140 & 14593 & 104895 & 51289 & -296 & 16032 & 86485 & 35303 & $1.45 * *$ \\
\hline
\end{tabular}

Source: Authors' calculations from the Estonian HFCS.

Notes: ${ }^{*},{ }^{* *},{ }^{* * *}$ refer to $10 \%, 5 \%$, and $1 \%$ statistical significance in the t-test of equality of mean values of men and women.

The difference in the ownership of business wealth between men and women is striking, men have nine times as much business wealth as women. Earlier findings from German data have shown this difference to be 5.5 times (Sierminska et al. (2010)). There is also evidence that women get to the top of the rich list mostly via inheritance, while men get there mostly via selfmade business wealth (Edlund and Kopczuk (2009)). In the Estonian sample, the difference stems mainly from the gap in the value of this item and less from differences in item participation, see Table 3 for participation rates of wealth items. About $14 \%$ of men and $6 \%$ of women have some self-employment business wealth, but conditional on having this item, the average value of the business is 99 thousand euros for men and 25 thousand euros for women. The gender gap in liabilities is smaller than the gender gap in net wealth, women have $29 \%$ less in liabilities than men. 
Table 3: Participation rates for individual-level net wealth components by gender

\begin{tabular}{lccc}
\hline & $\begin{array}{c}\text { Participation, } \\
\text { men }\end{array}$ & $\begin{array}{c}\text { Participation, } \\
\text { women }\end{array}$ & $\begin{array}{c}\text { Ratio of } \\
\text { participation rates, } \\
\text { men/women }\end{array}$ \\
\hline Total assets & 93.7 & 95.6 & $0.98^{*}$ \\
Total real assets & 75.3 & 71.2 & $1.06^{* *}$ \\
$\ldots$. real estate & 60.3 & 66.0 & $0.91^{* * *}$ \\
$\ldots$.. vehicles & 48.1 & 17.3 & $2.78^{* * *}$ \\
$\ldots$.. self-employment businesses & 13.9 & 5.9 & $2.36^{* * *}$ \\
Total financial assets & 88.0 & 92.3 & $0.95^{* * *}$ \\
$\ldots$ deposits & 86.6 & 91.8 & $0.94^{* * *}$ \\
$\ldots$.. stocks and bonds & 4.4 & 2.6 & $1.73^{* *}$ \\
$\ldots$ private pensions & 13.6 & 13.1 & 1.04 \\
Total liabilities & 43.1 & 40.0 & 1.08 \\
$\ldots$ loans & 33.9 & 31.4 & 1.08 \\
$\ldots$ bank overdrafts and credit card debt & 23.7 & 21.7 & 1.09 \\
\hline
\end{tabular}

Source: Authors' calculations from the Estonian HFCS.

Notes: ${ }^{*}, * * * * *$ refer to $10 \%, 5 \%$, and $1 \%$ statistical significance in the t-test of equality of mean values of men and women.

Table 4 shows the descriptive statistics for net wealth for different household types. The shares of individuals and households in each household type are given in Appendix 1. The mean gender wealth gap for the whole population originates from couple-headed households, while there is no statistically significant mean gender wealth gap for single-member households or for other types of households (with two adults not forming a couple or with more than two adults). The gap is substantial in the households headed by married couples, as men have on average $89 \%$ more wealth than women in this subgroup. Among cohabiting couple-headed households the gap is also significant and large at $61 \%$.

Wealth is more equally distributed across household types for women than for men. There is a striking difference between married men and single men - married men have on average more than two times as much wealth as single men, while cohabiting men own about half as much wealth as married men. The mean level of net wealth is the highest for married men with children.

Overall, the gap in net wealth is evident for couples and it is largest for married couples with children. These regularities point to the different penalties and gains that marriage and having children imply to men and women or to the endogenous decision to marry. It has been found that marriage creates positive wealth premiums for both men and women, but women tend to gain lower premiums in financial assets than men do (Lersch (2017)). 
Table 4: Descriptive statistics of individual-level net wealth by household type

\begin{tabular}{|c|c|c|c|c|c|c|c|c|c|}
\hline & \multicolumn{4}{|c|}{ Men } & \multicolumn{4}{|c|}{ Women } & \multirow{2}{*}{$\begin{array}{c}\text { Men/ } \\
\text { women, } \\
\text { ratio of } \\
\text { means } \\
\end{array}$} \\
\hline & $\begin{array}{c}\text { 10th } \\
\text { quantile }\end{array}$ & $\begin{array}{c}\text { 50th } \\
\text { quantile }\end{array}$ & $\begin{array}{c}\text { 90th } \\
\text { quantile }\end{array}$ & Mean & $\begin{array}{c}\text { 10th } \\
\text { quantile }\end{array}$ & $\begin{array}{c}\text { 50th } \\
\text { quantile }\end{array}$ & $\begin{array}{c}\text { 90th } \\
\text { quantile }\end{array}$ & Mean & \\
\hline $\begin{array}{l}\text { One adult, never } \\
\text { married }\end{array}$ & 10 & 5737 & 35107 & 26550 & 21 & 6512 & 39671 & 33865 & 0.78 \\
\hline $\begin{array}{l}\text { One adult, } \\
\text { widowed }\end{array}$ & 380 & 20960 & 52120 & 38231 & 6377 & 22588 & 52097 & 34748 & 1.10 \\
\hline $\begin{array}{l}\text { One adult, } \\
\text { divorced }\end{array}$ & 2 & 11412 & 28245 & 38241 & 2484 & 21912 & 50251 & 35211 & 1.09 \\
\hline $\begin{array}{l}\text { Two adults, } \\
\text { married }\end{array}$ & 97 & 30218 & 127170 & 81607 & 1 & 25091 & 100308 & 43120 & $1.89 *$ \\
\hline ... with children & 8511 & 25525 & 62756 & 106249 & 3182 & 17597 & 44206 & 37643 & $2.82 * *$ \\
\hline $\begin{array}{l}\text { Two adults, } \\
\text { cohabiting }\end{array}$ & -1208 & 6980 & 107780 & 40557 & -3982 & 4899 & 74026 & 25183 & $1.61 * *$ \\
\hline ... with children & 40 & 10910 & 42373 & 47136 & 0 & 4796 & 34125 & 26293 & $1.79 * *$ \\
\hline $\begin{array}{l}\text { Other two adults } \\
\text { or more than two } \\
\text { adults }\end{array}$ & 1 & 2512 & 28075 & 30909 & 100 & 8889 & 46452 & 33112 & 0.93 \\
\hline
\end{tabular}

Source: Authors' calculations from the Estonian HFCS.

Notes: ${ }^{* * *},{ }^{* * *}$ refer to $10 \%, 5 \%$, and $1 \%$ statistical significance in the t-test of equality of mean values of men and women.

\subsection{Methods}

This paper studies the factors behind the gender wealth gap and uses regression analysis and decomposition methods for this purpose. The typical problem with wealth data is that they violate the standard assumptions of least-squared based estimates. The distribution of wealth is strongly positively skewed as a large share of wealth is owned by a few wealthy households. The usual logarithmic transformation cannot be applied to solve this problem because the net wealth data contain many non-positive values. In the Estonian dataset used in this paper 12\% of individuals have negative net wealth and $4 \%$ have zero.

One solution for such data is to use an inverse hyperbolic sine (IHS) transformation. How suitable this transformation is for regression analysis with wealth data is thoroughly discussed by Pence (2006). The net wealth $w_{i}$ is transformed as follows:

$$
\sinh ^{-1}\left(\mathrm{w}_{\mathrm{i}}\right)=\ln \left(\mathrm{w}_{\mathrm{i}}+\left(\mathrm{w}_{\mathrm{i}}^{2}+1\right)^{1 / 2}\right)
$$

Applying this formula transforms all the negative values to positive and results in a distribution that is close to normal ${ }^{4}$. The transformation resembles a linear function around zero values and a logarithmic function for larger values. This makes it hard to interpret the regression coefficients, since the values close to zero can be interpreted as an untransformed variable in euros, while larger values can be interpreted like those for the logarithmic transformation (see

\footnotetext{
${ }^{4}$ The transformation also contains a scaling parameter, which makes the transformation more flexible and allows the left tail to be accommodated in the distribution of the transformed variable. The scaling parameter has been taken to equal one in this paper as this made the distribution of the transformed variable closest to the normal distribution.
} 
more discussion in Pence (2006)). As the net wealth grows quickly to very high values (medians are typically in the tens of thousands of euros) the coefficients of the regression analysis can be interpreted as being based on logarithmic transformation for most of the net wealth distribution, starting from the 20th quantile.

Given these properties of the wealth data, this paper uses quantile regressions to analyse how the explanatory variables affect net wealth. The advantage of quantile regressions is that they are less sensitive than mean-based estimates to outlier values of the dependent variable. The unconditional quantile regression suggested by Firpo et al. (2009) is applied to estimate the size of the conditional gender wealth gap over the distribution of wealth and to decompose the raw gap into explained and unexplained parts. Like with conditional quantile regressions, the regression coefficients can have different effects across the distribution, but unlike the conditional quantile regression, the unconditional quantile regression allows straightforward interpretation in terms of the unconditional distribution of the dependent variable. Earlier studies on the gender wealth gap that use individual-level data used the inverse probability weighting proposed by DiNardo et al. (1996) for the decomposition. This approach was used by Sierminska et al. (2010) and Bonnet et al. (2013) among others.

The unconditional quantile regression is based on a recentered influence function, where a distributional statistic such as a quantile is expressed in terms of an influence function that shows how much influence or weight each observation has for that particular statistic. The influence function is weighted so that its average value equals the value of the distributional statistic and an OLS with a recentered influence function as a dependent variable can be estimated to get the effect of explanatory variables on the particular quantile. Equation (4) illustrates the specification:

$$
R I F\left(w_{i} ; Q_{\tau}\right)=\alpha_{0, \tau}+\sum_{k=1}^{K} \alpha_{k, \tau} x_{i, \tau}^{k}+\varepsilon_{i, \tau}
$$

where $R I F\left(w_{i} ; Q_{\tau}\right)$ denotes the recentered influence function of the net wealth of individual $i w_{i}$ at the $\tau^{\text {th }}$ quantile $Q_{\tau} ; x^{k}$ denotes an explanatory variable; $\alpha_{0, \tau}$ and $\alpha_{k, \tau}$ denote the effects of the explanatory variables on the $\tau^{\text {th }}$ quantile of net wealth; and $\varepsilon_{i, \tau}$ is an error term. The estimates are performed for nine wealth quantiles from the $10^{\text {th }}$ quantile to the $90^{\text {th }}$.

Another advantage of this method is that unlike the method of inverse probability weighting developed by DiNardo et al. (1996), the RIF approach allows path-independent detailed decomposition of the contribution of each explanatory variable to the gender wealth gap (Fortin et al. (2011)). We use the Oaxaca-Blinder decomposition based on the RIF regressions for men and women at a particular quantile ${ }^{5}$. The standard decomposition is:

$$
\bar{W}_{M, \tau}-\bar{W}_{F, \tau}=\left(\bar{X}_{M}-\bar{X}_{F}\right) a_{M, \tau}+\bar{X}_{F}\left(a_{M, \tau}-a_{F, \tau}\right)
$$

where $\bar{W}_{M, \tau}$ and $\bar{W}_{F, \tau}$ represent the net wealth of men and women, $\bar{X}_{M}$ and $\bar{X}_{F}$ denote the average values of explanatory variables for men and women, and $a_{M, \tau}$ and $a_{F, \tau}$ are the coefficients from separate regressions for men and women. The decomposition is run for quantiles $\tau$ based on the RIF regression for the quantile so that the left-hand-side is the difference between the wealth of men and the wealth of women at a particular quantile of the wealth distribution (measured as the average value of the recentered influence function for the quantile) and the right-hand-

\footnotetext{
${ }^{5}$ The software used in Stata was rifreg, provided by Fortin based on Firpo et al. (2009), and oaxaca8 by Jann (2005).
} 
side is derived from the coefficients for this quantile and the average values of the explanatory variables.

The decomposition analysis allows the unconditional gender wealth gap to be disentangled into two components, the explained part and the unexplained part, which are shown as the first and second terms on the right-hand-side of equation (5). The explained part captures the part of the gender wealth gap caused by differences in the characteristics of men and women, such as their employment status, work experience, income or education. The unexplained part captures the part of the gender wealth gap that cannot be explained by observable characteristics, and it originates from different returns on variables, e.g. self-employed men accumulating more wealth than self-employed women, etc. This part is often attributed to discrimination in wage regressions and is interpreted as differences in the wealth function of men and women in studies on wealth.

The results of the decomposition depend on the set of coefficients used as the base in the decomposition. The coefficients for men have been used as the base in this paper, which implies that the explained part is interpreted as though women had the same returns as men but different characteristics, and the unexplained part as though men had the same characteristics as women but different returns. The base coefficients for men have been used as this provides the most straightforward interpretation of how large the unexplained gender wealth gap would be if women were similar to men in their returns to characteristics.

Five groups of explanatory variables are used in the decomposition: (1) labour market experience, (2) income, (3) education, (4) demographics, and (5) geographical region. The set of explanatory variables is similar to what has been used in the related papers on the gender wealth gap. Unlike some earlier studies we do not have individual-level data on inheritance or on parents' education, but these variables have very little explanatory power in explaining the gender wealth gap in earlier studies (Sierminska et al. (2010), Bonnet et al. (2010)). Unlike other studies we also control for the field of education and geographical region. The field of education can be used as a proxy for financial literacy, which is not available in the dataset. It has been shown that financial knowledge affects individuals' long-term financial planning (e.g. Lusardi (2008)). Regional dummies capture regional disparities in asset accumulation because of regional differences in house prices, the availability of financial services, and other aspects.

The group of variables related to labour market experience contains the following variables: labour market status, work experience, and work experience squared. The variable describing labour market status has seven categories: worker, self-employed, unemployed, student, retired, disabled, doing domestic work, and other non-active. Work experience is measured as years worked for most of the year since the age of 16. The set of variables related to income contains the total income of the last calendar year and total income squared. Total income is gross annual income from employment, self-employment and public and private transfers in thousands of euros.

The set of explanatory variables on education covers the level of education and the field of education. The level of education is measured in three categories: primary (ISCED-97 0-2), secondary (ISCED-97 3-4) and tertiary (ISCED-97 5-6). The field of education is measured in nine broad fields of education taken from ISCED-97: 0 - General programmes, 1 - Education, 2 - Humanities and arts, 3 - Social sciences, business and law, 4 - Science, 5 - Engineering, manufacturing and construction, 6 - Agriculture, 7 - Health and welfare, 8 - Services. The demographic variables are age, age squared, immigration status, number of children (one, two 
and three or more), a dummy for at least one child younger than three, and marital status (single, never married; widowed; divorced; married; and cohabiting). The regional variables capture five major regions of the country at NUTS-3 level and the degree of urbanisation (capital, other town and countryside).

\section{Results from administrative wealth data}

\subsection{Baseline results}

Table 5 shows the regression results for the $50^{\text {th }}$ net wealth quantile using the recentered influence function and net wealth transformed by inverse hyperbolic sine. The coefficient on the male dummy in column (1) is statistically insignificant, showing that when observable characteristics are controlled for there is no gender wealth gap among individuals at the median level of net wealth.

Table 5: The net wealth regressions, RIF estimates for the median

\begin{tabular}{|c|c|c|c|}
\hline & $\begin{array}{c}\text { (1) } \\
\text { All individuals }\end{array}$ & $\begin{array}{c}(2) \\
\text { Men }\end{array}$ & $\begin{array}{c}(3) \\
\text { Women }\end{array}$ \\
\hline Men, base women & $\begin{array}{l}-0.009 \\
(0.096)\end{array}$ & & \\
\hline Status self-employed, base employee & $\begin{array}{c}0.857^{* * * *} \\
(0.189)\end{array}$ & $\begin{array}{c}0.979^{* * * *} \\
(0.256)\end{array}$ & $\begin{array}{c}0.908^{* * * *} \\
(0.309)\end{array}$ \\
\hline Status unemployed, base employee & $\begin{array}{c}-0.403^{* * *} \\
(0.194)\end{array}$ & $\begin{array}{r}-0.410 \\
(0.298)\end{array}$ & $\begin{array}{c}-0.198 \\
(0.267)\end{array}$ \\
\hline Status student, base employee & $\begin{array}{l}-0.149 \\
(0.253)\end{array}$ & $\begin{array}{l}-0.629 \\
(0.436)\end{array}$ & $\begin{array}{c}0.120 \\
(0.305)\end{array}$ \\
\hline Status retiree, base employee & $\begin{array}{c}-0.497^{* *} \\
(0.198)\end{array}$ & $\begin{array}{c}-0.486^{*} \\
(0.295)\end{array}$ & $\begin{array}{l}-0.433 \\
(0.273)\end{array}$ \\
\hline Status disabled, base employee & $\begin{array}{c}-0.683^{* * *} \\
(0.222)\end{array}$ & $\begin{array}{c}-0.870^{* * *} \\
(0.330)\end{array}$ & $\begin{array}{l}-0.492 \\
(0.319)\end{array}$ \\
\hline Status performing domestic tasks, base employee & $\begin{array}{c}-0.483^{* *} \\
(0.222)\end{array}$ & $\begin{array}{c}-1.371^{\text {**** }} \\
(0.488)\end{array}$ & $\begin{array}{l}-0.193 \\
(0.250)\end{array}$ \\
\hline Status other non-active, base employee & $\begin{array}{c}0.506 \\
(0.645)\end{array}$ & $\begin{array}{c}-1.574^{* * *} \\
(0.316)\end{array}$ & $\begin{array}{l}1.174^{* *} \\
(0.518)\end{array}$ \\
\hline Time in employment & $\begin{array}{c}0.001 \\
(0.014)\end{array}$ & $\begin{array}{l}-0.015 \\
(0.023)\end{array}$ & $\begin{array}{c}0.011 \\
(0.019)\end{array}$ \\
\hline Time in employment squared / 100 & $\begin{array}{c}0.021 \\
(0.027)\end{array}$ & $\begin{array}{c}0.059 \\
(0.043)\end{array}$ & $\begin{array}{c}-0.008 \\
(0.036)\end{array}$ \\
\hline Income, thousand EUR & $\begin{array}{c}0.025^{* * *} \\
(0.005)\end{array}$ & $\begin{array}{c}0.023^{* * * *} \\
(0.007)\end{array}$ & $\begin{array}{c}0.028^{* * * *} \\
(0.005)\end{array}$ \\
\hline Income squared /100 & $\begin{array}{c}-0.0004^{* * *} \\
(0.0001)\end{array}$ & $\begin{array}{c}-0.0004^{* * *} \\
(0.0001)\end{array}$ & $\begin{array}{c}-0.0005^{* * * *} \\
(0.0001)\end{array}$ \\
\hline Secondary education, base primary & $\begin{array}{c}0.581^{* * * *} \\
(0.148)\end{array}$ & $\begin{array}{c}0.688^{* * * *} \\
(0.230)\end{array}$ & $\begin{array}{l}0.509^{* * *} \\
(0.212)\end{array}$ \\
\hline Tertiary education, base primary & $\begin{array}{l}1.221^{* * *} \\
(0.203)\end{array}$ & $\begin{array}{l}1.605^{* * *} \\
(0.320)\end{array}$ & $\begin{array}{l}1.072^{* * *} \\
(0.281)\end{array}$ \\
\hline Training in education, base general programmes & $\begin{array}{c}0.120 \\
(0.270)\end{array}$ & $\begin{array}{c}0.631 \\
(0.628)\end{array}$ & $\begin{array}{c}0.103 \\
(0.307)\end{array}$ \\
\hline Training in humanities, base general programmes & -0.027 & $-1.207^{* *}$ & 0.256 \\
\hline
\end{tabular}




\begin{tabular}{|c|c|c|c|}
\hline \multirow{3}{*}{ Training in social sciences, base general programmes } & $(0.285)$ & $(0.503)$ & $(0.345)$ \\
\hline & 0.048 & $-0.541^{*}$ & 0.186 \\
\hline & $(0.178)$ & $(0.326)$ & $(0.223)$ \\
\hline \multirow[t]{2}{*}{ Training in science, base general programmes } & -0.137 & -0.018 & -0.356 \\
\hline & $(0.360)$ & $(0.651)$ & $(0.373)$ \\
\hline \multirow[t]{2}{*}{ Training in engineering, base general programmes } & 0.225 & 0.055 & 0.294 \\
\hline & $(0.142)$ & $(0.203)$ & $(0.224)$ \\
\hline \multirow[t]{2}{*}{ Training in agriculture, base general programmes } & -0.082 & -0.021 & -0.038 \\
\hline & $(0.254)$ & $(0.408)$ & $(0.338)$ \\
\hline \multirow[t]{2}{*}{ Training in health, base general programmes } & 0.094 & -0.147 & 0.139 \\
\hline & $(0.260)$ & $(0.657)$ & $(0.288)$ \\
\hline \multirow[t]{2}{*}{ Training in services, base general programmes } & 0.124 & 0.085 & 0.203 \\
\hline & $(0.169)$ & $(0.269)$ & $(0.257)$ \\
\hline \multirow[t]{2}{*}{ Age } & $0.168^{* * *}$ & $0.143^{* * * *}$ & $0.197^{* * *}$ \\
\hline & $(0.024)$ & $(0.038)$ & $(0.031)$ \\
\hline \multirow[t]{2}{*}{ Age squared / 100} & $-0.117^{* * *}$ & $-0.097^{* *}$ & $-0.141^{* * * *}$ \\
\hline & $(0.023)$ & $(0.038)$ & $(0.030)$ \\
\hline \multirow[t]{2}{*}{ Immigrant, base born in Estonia } & -0.187 & -0.343 & -0.040 \\
\hline & $(0.135)$ & $(0.214)$ & $(0.176)$ \\
\hline \multirow[t]{2}{*}{ One child, base no children } & 0.064 & 0.075 & -0.010 \\
\hline & $(0.124)$ & $(0.206)$ & $(0.160)$ \\
\hline \multirow[t]{2}{*}{ Two children, base no children } & 0.134 & 0.217 & 0.090 \\
\hline & $(0.144)$ & $(0.229)$ & $(0.191)$ \\
\hline \multirow[t]{2}{*}{ Three children, base no children } & 0.343 & 0.418 & 0.239 \\
\hline & $(0.221)$ & $(0.332)$ & $(0.309)$ \\
\hline \multirow[t]{2}{*}{ Child under three years, base other } & 0.198 & 0.037 & $0.454^{* *}$ \\
\hline & $(0.158)$ & $(0.255)$ & $(0.211)$ \\
\hline \multirow[t]{2}{*}{ Marital status widow, base single/never married } & 0.018 & -0.251 & 0.044 \\
\hline & $(0.238)$ & $(0.493)$ & $(0.281)$ \\
\hline \multirow[t]{2}{*}{ Marital status divorced, base single/never married } & -0.063 & -0.362 & 0.074 \\
\hline & $(0.210)$ & $(0.358)$ & $(0.271)$ \\
\hline \multirow[t]{2}{*}{ Marital status married, base single/never married } & $0.471^{* * *}$ & $0.735^{* *}$ & 0.237 \\
\hline & $(0.171)$ & $(0.294)$ & $(0.219)$ \\
\hline \multirow[t]{2}{*}{ Marital status cohabiting, base single/never married } & -0.134 & -0.154 & -0.170 \\
\hline & $(0.169)$ & $(0.278)$ & $(0.220)$ \\
\hline \multirow[t]{2}{*}{ Region north, base central Estonia } & $0.841^{* * *}$ & $0.487^{*}$ & $1.178^{* * *}$ \\
\hline & $(0.185)$ & $(0.290)$ & $(0.251)$ \\
\hline \multirow[t]{2}{*}{ Region west, base central Estonia } & $0.425^{* *}$ & 0.214 & $0.565^{* *}$ \\
\hline & $(0.191)$ & $(0.293)$ & $(0.262)$ \\
\hline \multirow[t]{2}{*}{ Region south, base central Estonia } & 0.108 & 0.127 & 0.148 \\
\hline & $(0.176)$ & $(0.272)$ & $(0.242)$ \\
\hline \multirow[t]{2}{*}{ Region east, base central Estonia } & $-0.685^{* * *}$ & $-0.718^{* *}$ & -0.391 \\
\hline & $(0.204)$ & $(0.323)$ & $(0.280)$ \\
\hline \multirow[t]{2}{*}{ Other town, base capital town } & $0.345^{* *}$ & 0.124 & $0.513^{* *}$ \\
\hline & $(0.159)$ & $(0.258)$ & $(0.208)$ \\
\hline \multirow[t]{2}{*}{ Village, base capital town } & 0.192 & 0.229 & 0.202 \\
\hline & $(0.146)$ & $(0.239)$ & $(0.189)$ \\
\hline$N$ & 4227 & 1978 & 2249 \\
\hline $\operatorname{adj} . R^{2}$ & 0.211 & 0.230 & 0.192 \\
\hline
\end{tabular}

Source: Authors' calculations from the Estonian HFCS.

Notes: The values of net wealth are IHS-transformed. Standard errors in parentheses. ${ }^{*},{ }^{* *},{ }^{* * *}$ refer to statistical significance at $10 \%, 5 \%$ and $1 \%$ level.

The figures presented in Columns (2) and (3) in Table 5 show that there are some differences between men and women in how the explanatory variables affect net wealth, indicating that the 
wealth functions of men and women may differ. The differences between the estimated coefficients for men and women are mostly not statistically significant, but there are cases where the point estimates differ and it is worth highlighting these dissimilarities. The difference between the regression coefficients is statistically significant for income, and is higher for women. This implies that women accumulate more wealth than men with the same income level. However, the magnitudes of the estimated effects are quite close, indicating that the differences in the wealth function related to income are modest.

Labour market status affects the net wealth of men differently from how it affects women, as men tend to have lower wealth when their status is given as inactive but the same does not hold for women. Having young children aged below three affects the net wealth of women positively, while having young children does not affect the wealth of men. Married men have more wealth than single men do, while women's wealth does not differ with their marital status. There are also some differences across regions as women tend to gain more from living in richer regions like the north and west and in towns, while men tend to have more equal wealth across regions, but have a strong penalty from living in the industrial eastern region. Several variables do not have significant explanatory power for net wealth. These include the variables describing work experience, immigrant status and the number of children.

The results presented in Table 5 refer only to the median and show that conditional on the standard explanatory variables, the gender wealth gap is statistically insignificant. However, the conditional gender wealth gap can be different for other parts of the distribution of net wealth. Appendix 2 presents the regression results for the $10^{\text {th }}, 20^{\text {th }}, 30^{\text {th }}$, etc. quantiles, except the median. The coefficients for the male dummy variable are positive and significant for the $10^{\text {th }}$ quantile and for the $80^{\text {th }}$ and $90^{\text {th }}$ quantile. This implies that the conditional gender wealth gap has a U-shape pattern over the net wealth distribution.

We go further in studying the conditional gender wealth gap by using the decomposition method described in equation (5). The results of the detailed decomposition over the quantiles of net wealth are presented in Appendix 3. The first row of the table in Appendix 3 depicts the values of the raw or unconditional gender wealth gaps across net wealth quantiles. The figures presented repeat the message from the descriptive statistics and from the regression results that women have more wealth than men in the lower part of the wealth distribution, while men have more wealth than women at the top values of wealth. As the standard errors are large, the raw gap is only statistically significant at the $20^{\text {th }}$ and $90^{\text {th }}$ quantiles and remains insignificant across most of the net wealth distribution. The explained part of the gender wealth gap is statistically significant only at the $90^{\text {th }}$ quantile. Like the raw gap, the unexplained gap is estimated with large uncertainty so it is marginally significant at the $10 \%$ level only for the $30^{\text {th }}$ quantile.

The gender wealth gap can be explained by the following variables: self-employment, retirement (upper part of the wealth distribution), secondary education (upper part of the wealth distribution), training in engineering (lower part of the wealth distribution) and marriage (middle part of the distribution). Men are more likely to be self-employed than women and are therefore wealthier. In the upper part of the wealth distribution, women are more likely to be retired than men. As being retired is associated with lower wealth, taking this into account helps to explain the gender wealth gap. Men are more likely to have training in engineering, which helps to explain the wealth gap in the lower part of the distribution. 
The variables that widen the unexplained gender wealth gap (i.e. for which the estimated effects for the explained part are negative) are tertiary education, age, and the labour market status of being disabled (lower part of the wealth distribution). Women are more likely to have tertiary education and are in general older than men because their life expectancy is higher. Taking account of these factors increases the unexplained part of the wealth gap. Men in the lower part of the wealth distribution are more likely to be inactive in the labour market because of disability. As this labour market status is associated with lower wealth, taking this into account increases the unexplained part of the gender wealth gap.

The variables that contribute positively to the unexplained part of the wealth gap are selfemployment status (upper part of the wealth distribution) and training in science, engineering or agriculture (lower part of the distribution). This implies that being self-employed or having this type of education has higher returns in terms of wealth for men than for women. The variables that contribute negatively to the unexplained part of the wealth gap are time in employment (upper part of the wealth distribution) and age (lower part). The effects for regions are also occasionally significant, but with opposite signs.

Appendix 4 presents the results of the decomposition based on untransformed values for net wealth. The results are similar to those presented in Appendix 3. The raw gap is significantly in favour of men for the upper tail of the distribution, at and above the $90^{\text {th }}$ quantile, while the unexplained part of the decomposed gap remains mostly insignificant throughout the wealth distribution. The figures presented in Appendix 4 also show that net wealth is negative for both men and women in the $10^{\text {th }}$ wealth quantile and is around 100 euros in the $20^{\text {th }}$ quantile. These low values imply that despite the large gap in IHS transformed wealth in lower part of the wealth distribution, the contribution of this part to the mean gap is small.

The results of the decomposition based on the IHS-transformed net wealth are summarised in Figure 1. The unexplained gender wealth gaps are mostly close to the raw gaps, resembling a U-shape, like the raw gap. That the unexplained gaps follow the pattern of the raw gaps shows the limited and often offsetting explanatory power of the observed explanatory variables. The raw gap is statistically significant at the upper and lower ends of the net wealth distribution, as women have more wealth than men at the $20^{\text {th }}$ quantile and men have more wealth than women at the $90^{\text {th }}$ quantile. The unexplained gender gap is never statistically significant at the $95 \%$ confidence level and is marginally significant at the $90 \%$ level only at the $30^{\text {th }}$ quantile, where it is in favour of women. The descriptive statistics presented in Table 2 demonstrated that the large gender gap in mean unconditional net wealth is explained by large differences in net wealth between the wealthiest men and women, since there are many more men with high net wealth than women. 


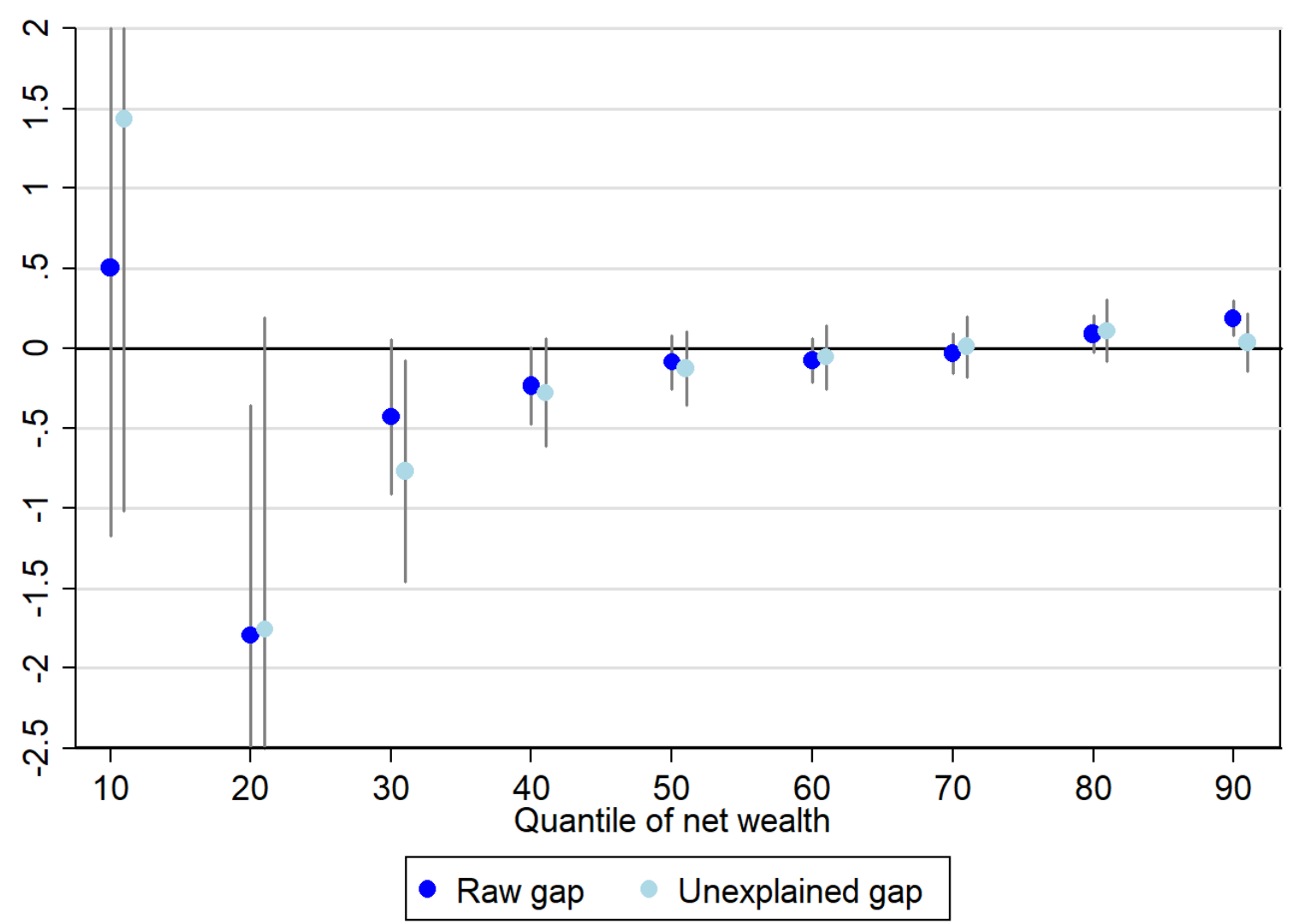

Figure 1: The raw gender wealth gap and the unexplained part of the gap across net wealth distribution, RIF based decomposition

Source: Authors' calculations from the Estonian HFCS.

Notes: The vertical axis shows the difference between men and women in IHS-transformed net wealth. The horizontal axis depicts the quantiles of net wealth. Confidence bounds refer to statistical significance at $10 \%$. The vertical scale has been trimmed at -2.5 and at 2 , so some confidence bounds are not shown in their full extension.

At the top of the net wealth distribution the raw gap is statistically significant, while the unexplained gap is insignificant. This implies that the gap can be explained to some extent by control variables. The detailed results of the decomposition (see Appendix 3 ) show that the only variable that has a significant positive effect on the explained part of the wealth gap at the $90^{\text {th }}$ quantile is the indicator of self-employment. Men are more likely to be self-employed than women, especially at the top of the wealth distribution. Since self-employed workers generally have higher levels of wealth (see Appendix 2), accounting for self-employment diminishes the unexplained part of the gender wealth gap.

We confirm the finding of the earlier literature that the most relevant determinants of the gender wealth gap are related to the labour market. Additionally, we find that an important reason why men have more wealth is that they are more likely to be entrepreneurs or selfemployed. Retirement also helps to explain the gender wealth gap, as women are more likely to be retired in the upper part of the wealth distribution and this has a negative effect on their wealth. Unlike the earlier studies we find that education also has explanatory power for the 
wealth gap. Men are more likely to have secondary education than women and women are more likely to have tertiary education than men. The net effect of time spent in education is in favour of women and reduces the gender gap in the upper part of the wage distribution. Like Sierminska et al. (2010) we find that there are parts of the wealth distribution where women have more wealth than men, conditional on the observed characteristics.

\subsection{Results by different components of net wealth}

As shown in Table 2 in the previous section, the allocation of resources within households can differ substantially for different wealth items. For example, real estate is mostly owned in equal shares by married couples, while men own much more in self-employment business assets than women. Chang (2010) points out that men and women have different compositions of wealth, resulting in different wealth building rates. The gender wealth gap was decomposed by wealth components by Schneebaum et al. (2016) for single-member households only. We extend the estimations to the full population, and we also distinguish the components of real and financial assets. Figure 2 illustrates the composition of assets over deciles of gross assets, showing that the asset structure for men is more diversified than that for women.

The level of net wealth is negative at the first decile and only about 100 EUR at the second decile. Given this, it is not surprising that bank deposits make up most of the assets for individuals in the first two deciles of the gross asset distribution and this holds for both genders. The asset structures for men and women start to diverge from the third decile. The differences in the composition of assets are largest in the third and fourth deciles and in the tenth decile. Vehicles make up a substantially larger share of assets for men than for women in the lower half of the distribution, while self-employment business wealth comprises a larger share of the assets of men than of those of women in the upper two deciles of the distribution. The difference in holdings of self-employment business assets between genders is especially large for the richest decile. All in all, men are likely to own more of their wealth in the form of vehicles and as self-employment businesses. It is also apparent that the wealth of men is more diversified, while women hold their wealth mostly in the form of two assets - real estate and deposits. Men are also more likely to own stocks, while women hold a larger share of their wealth as private pensions, but these differences are not large, since the holdings of stocks and private pension funds are small compared to holdings of other asset classes. Next, we look at whether gender wealth gaps are different for various components of net wealth. 

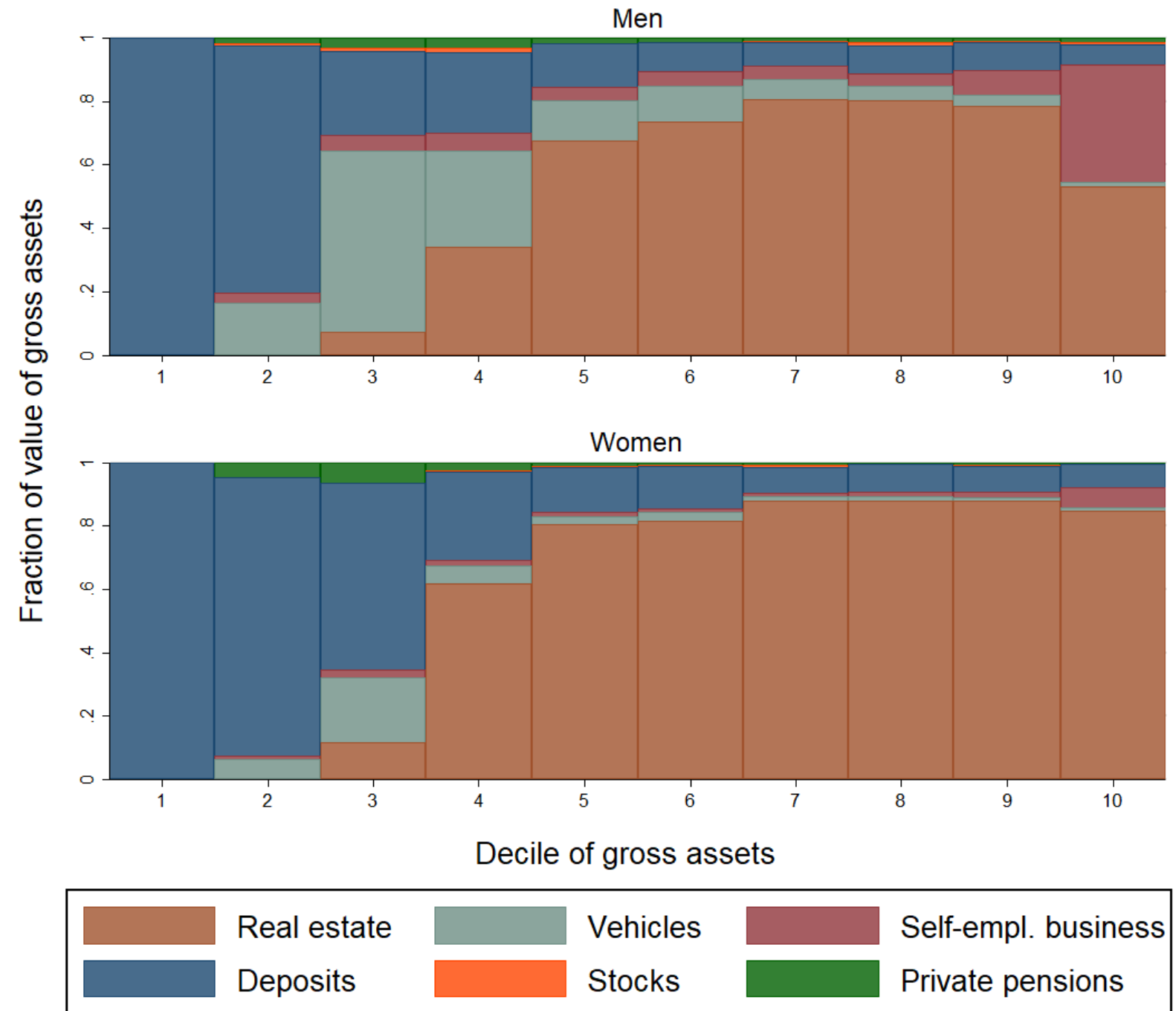

Figure 2: The shares of different types of assets for men and women, average values for deciles of gross assets

Source: Authors' calculations from the Estonian HFCS.

We estimate the raw and unexplained gender wealth gaps for various net wealth items, such as real estate, vehicles, self-employment businesses, deposits, stocks and bonds, private pensions, loans, and bank overdrafts and credit card debt. Net wealth was negative for part of the sample, but the values of different wealth items are always non-negative. Therefore we take logarithms of the values of different wealth items instead of using IHS transformation to tackle the problems associated with non-normal distributions of these items.

As already shown by the descriptive statistics, the participation in individual wealth items is very different. Relatively few people have stocks, bonds and mutual fund holdings, while most people have real estate and deposits. The RIF cannot be estimated for the parts of the distribution where there is no item participation, since the quantiles cannot be meaningfully defined for zero values of the wealth item. The decomposition requires the RIF regressions to 
be estimated for men and women at the same quantile, so the RIF based decomposition can be run only for observations with non-zero values for a particular asset.

Figure 3 presents the findings. ${ }^{6}$ The patterns of the raw and unexplained gaps are similar for vehicles, self-employment businesses, private pensions, loans, and bank overdrafts and credit card debt, indicating that the observed characteristics do not explain the wealth difference between men and women for these net wealth items. There are also cases where the explanatory variables can explain the difference better. The raw gaps are significantly different from zero but the unexplained gaps are insignificant for real estate in the upper part of the distribution and for deposits and loans in the middle of the distribution. Differences in characteristics explain why women's deposits and men's real estate holdings and loans are larger in those cases. The unexplained gap is significant for stocks and bonds in the middle part of the distribution, implying that women with the same characteristics hold less risky financial assets than men do.

The unexplained gender wealth gaps for different wealth items are quite divergent. The unexplained gap is statistically insignificant for real estate and loans for all net wealth quantiles. For the other real assets (vehicles and self-employed business wealth) the unexplained gap is in favour of men throughout most of the distribution, and it is strongly statistically significant and large. The share of self-employment business wealth in total real wealth is larger in Estonia than the euro area average and it is an important source of wealth inequality. ${ }^{7}$ Edlund and Kopczuk (2009) highlight the importance of self-employment business wealth in the raw gender wealth gap at the very top of the wealth distribution in the US. We cannot compare the results with those of other countries explicitly as no study has explored the role of self-employment wealth ${ }^{8}$, but our findings suggest that it is important not to neglect this wealth item when analysing the gender wealth gaps.

The unexplained gaps for financial assets are mostly in favour of women for deposits, but in favour of men for other, more risky financial assets and for private pensions. That men are accumulating more private pension wealth than women with similar characteristics implies that men will have more resources in their retirement than women.

\footnotetext{
${ }^{6}$ Some of the variables describing labour market status have been aggregated for the decomposition by wealth items. As we have many fewer observations at our disposal here, the inactivity status groups of student, disabled, doing domestic tasks, and other non-active have been aggregated into one group of non-active status. So in total there are five labour market status groups: employee, self-employed, unemployed, retired and other inactive. The shorter list of inactivity statuses has also been used for the decomposition of wealth for various household types in the next section, but the rest of the estimations in this paper use the full set of statuses based on eight groups.

7 The share of business wealth in Estonia is $20 \%$ of total real assets, while the average share in euro area countries is $11.8 \%$ of total real assets (HFCS (2016)).

${ }^{8}$ Sierminska et al. (2010) and Grabka et al. (2015) discuss only the raw gap in self-employment business, but do not condition it on individual characteristics.
} 

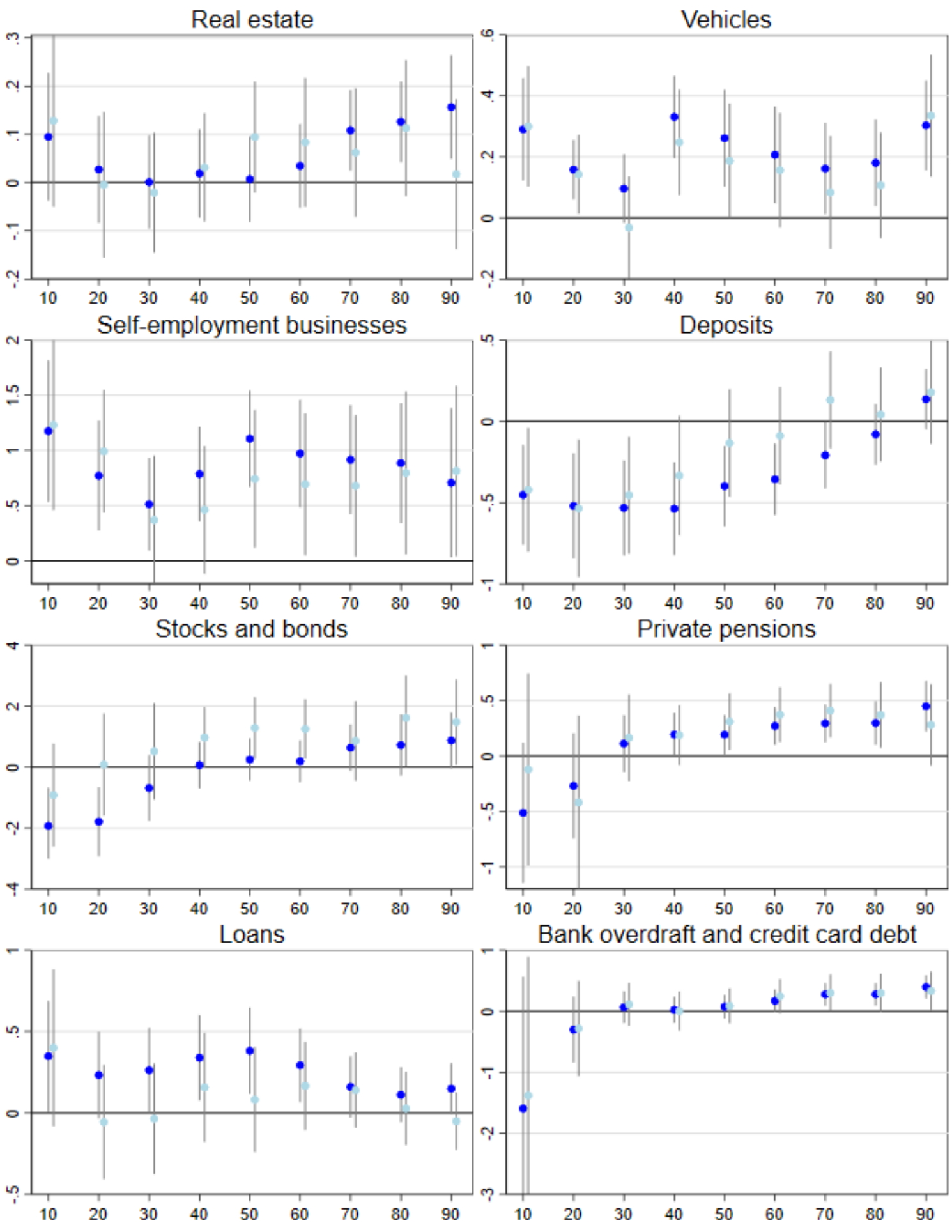

Raw gap

Unexplained gap

Figure 3: The gender gaps in quantiles of various net wealth items, RIF-based decomposition Source: Authors' calculations from the Estonian HFCS.

Notes: The vertical scale refers to the difference between the logarithmic values of a given wealth item for men and women. The wealth gaps are presented conditional on participation. Confidence bounds refer to statistical significance at $10 \%$. 
The differences between men and women in deposit holdings are large. Women have 50\% more in deposits than men in the lower half of the distribution and the raw gap is significant up to the $70^{\text {th }}$ quantile. Accounting for observable characteristics reduces the gap, but it still remains statistically significantly in favour of women below the $30^{\text {th }}$ quantile. The raw gap for other financial assets (stocks and bonds) is insignificant, but the unexplained gap is in favour of men in the middle part and upper end of the distribution. These findings highlight possible differences in risk aversion between men and women. Given the observable characteristics, it is apparent that women save more in deposits and men more in other financial assets such as stocks and bonds and voluntary pension schemes that are based on riskier instruments. The upshot of the estimations is that the gender wealth gap varies across asset types and the preference of men for riskier assets gives them greater capacity for building wealth.

The Estonian HFCS survey has a variable measuring risk aversion, but the response rate for the related question is low and we lose more than $20 \%$ of observations when we include this variable in the model. As a robustness test we perform the decomposition with a control for the risk aversion of men and women.

We add to the model a categorical variable capturing the financial risks taken when investing or saving on a scale of four options. ${ }^{9}$ Women are more risk averse than men, as $82 \%$ of women are not willing to take any financial risk, while the same applies to $68 \%$ of men. The results with the risk aversion variable added to the set of observable characteristics in the decomposition are given in Appendix 5. The results do not change substantially for most of the wealth items, but there are some changes, notably that the gap in deposits can be explained for the middle part of the distribution. The gap is also reduced for self-employment business assets, but this results from the omission of $20 \%$ of the sample from the regression and not from the additional explanatory power of the risk aversion variable. However, men have more stocks and bonds and women more deposits even after risk aversion is controlled for. These findings imply that either the risk aversion measure that we use does not capture differences in risk aversion to the full extent or there could be other factors that lead men and women to invest and save differently, which could be related to financial literacy, social norms or gender identity. We cannot investigate the explanations for the different compositions of wealth further as we do not have variables that could measure any other aspects.

\subsection{Results by household type}

In this subsection we show the results of the net wealth decomposition for different household types. To the best of our knowledge there exist no previous studies which have performed such decomposition. The descriptive statistics in Table 4 showed that there was a large and statistically significant unconditional gender gap in mean net wealth among couple-headed households, but for all other household types the differences in the mean levels of net wealth were insignificant. We assess the extent of the raw and unexplained gaps for different household types across net wealth quantiles and the results are presented in Table 6 . These estimates show that, as with the unconditional findings for mean wealth, the raw gaps for different quantiles

\footnotetext{
${ }^{9}$ The answer options are: 1 - Take substantial financial risks expecting to earn substantial returns; 2 - Take above average financial risks expecting to earn above average returns; 3 - Take average financial risks expecting to earn average returns; 4 - Not willing to take any financial risk.
} 
are significantly positive throughout most of the net wealth distribution for households with married couples, but are only occasionally significantly different from zero for other household types. When they are significant, the raw gaps are positive for couple-headed households, but negative (i.e. in favour of women) for single people and for households that are not coupleheaded or have more than two adult members.

Table 6: The gender gaps for quantiles of net wealth and across different household types

\begin{tabular}{|c|c|c|c|c|c|c|c|c|}
\hline & \multicolumn{2}{|c|}{ One adult } & \multicolumn{2}{|c|}{$\begin{array}{l}\text { Two adults, } \\
\text { married }\end{array}$} & \multicolumn{2}{|c|}{$\begin{array}{l}\text { Two adults, } \\
\text { cohabiting }\end{array}$} & \multicolumn{2}{|c|}{$\begin{array}{l}\text { Other two adults or } \\
\text { three or more adults }\end{array}$} \\
\hline & Raw gap & $\begin{array}{l}\text { Unex- } \\
\text { plained } \\
\text { gap }\end{array}$ & Raw gap & $\begin{array}{l}\text { Unex- } \\
\text { plained } \\
\text { gap }\end{array}$ & Raw gap & $\begin{array}{c}\text { Unex- } \\
\text { plained } \\
\text { gap }\end{array}$ & Raw gap & $\begin{array}{c}\text { Unex- } \\
\text { plained } \\
\text { gap }\end{array}$ \\
\hline $10^{\text {th }}$ quantile & -0.598 & 0.700 & 2.833 & -3.65 & 1.181 & 1.767 & -1.462 & -2.282 \\
\hline $20^{\text {th }}$ quantile & $-5.009^{* * * *}$ & $-2.968^{* * *}$ & $0.581^{*}$ & 0.282 & $9.532^{* * *}$ & $6.913^{* * *}$ & -1.280 & -1.764 \\
\hline $30^{\text {th }}$ quantile & $-3.700^{* * *}$ & -1.351 & $0.290^{* *}$ & 0.142 & $3.329^{*}$ & 0.833 & $-3.377^{* * *}$ & $-3.514^{* * *}$ \\
\hline $40^{\text {th }}$ quantile & $-1.451^{* *}$ & -0.845 & $0.268^{* * *}$ & 0.151 & $1.619^{*}$ & 1.13 & $-0.745^{*}$ & -0.713 \\
\hline $50^{\text {th }}$ quantile & -0.665 & 0.385 & $0.187^{* *}$ & 0.051 & 0.430 & -0.182 & $-1.149^{* * * *}$ & -0.599 \\
\hline $60^{\text {th }}$ quantile & -0.583 & 0.632 & $0.228^{* * *}$ & 0.098 & 0.496 & 0.216 & $-0.836^{* * *}$ & $-0.896^{*}$ \\
\hline $70^{\text {th }}$ quantile & -0.406 & 0.513 & $0.274^{* * *}$ & 0.135 & 0.231 & -0.024 & $-0.625^{* *}$ & $-0.751^{*}$ \\
\hline $80^{\text {th }}$ quantile & -0.207 & $1.254^{* * *}$ & $0.252^{* * *}$ & 0.062 & 0.011 & -0.196 & -0.215 & -0.285 \\
\hline $90^{\text {th }}$ quantile & 0.120 & 0.819 & $0.234^{* *}$ & 0.024 & 0.339 & 0.022 & 0.000 & -0.165 \\
\hline
\end{tabular}

Source: Authors' calculations from the Estonian HFCS.

Notes: The values of net wealth are IHS-transformed. ${ }^{*},{ }^{* *},{ }^{* * *}$ refer to statistical significance at the $10 \%, 5 \%$ and $1 \%$ level.

Single-member households are more heterogeneous than partner-headed households as this group consists of single people who have never married, or are widowed or divorced. This means that the conditional wealth gap is more informative than the unconditional gap. The results of the model-based decomposition for single-member households are presented in Appendix 6. After observable characteristics are controlled for, the negative wealth gaps in the lower part of the distribution are mostly rendered insignificant and the unexplained gap is significantly negative for the $20^{\text {th }}$ quantile only. In the upper part of the distribution the unexplained gap is significantly positive for the $80^{\text {th }}$ quantile. So, when we account for observable characteristics then the unexplained gaps are more in favour of men than the raw gaps were. This implies that the characteristics of single women are better suited for contributing to wealth accumulation than those of single men are. Backing this up, the explained parts of the gender wealth gaps are negative and statistically significant for most of the net wealth quantiles (see the first row of the table in Appendix 6). The most important characteristics that contribute negatively to the gender wealth gap for single-member households are training in education and having a child. Apparently men who have training in education and are single parents usually have more wealth, and as women are more frequently found in these categories than men are, taking account of this turns the unexplained wealth gap more in favour of men. 
The finding that accounting for observable characteristics for single-headed households renders the unexplained gap more in favour of men is similar to the finding of the study by Schmidt and Sevak (2006) focusing on single-member households only. They find that the observed wealth of single men and women is similar, but when observable characteristics are controlled for, women's wealth drops well below that of men.

The unexplained gaps for partner-headed households are mostly statistically insignificant, indicating that differences in characteristics can explain the wealth gap between male and female partners (see Appendices 6 and 7 for results). The wealth gap remains unexplained and large for some less wealthy cohabiting partners, but it is well explained for the wealthiest married couples, for whom the gap is the largest in monetary terms. The characteristics that help to explain the gap for married couples are self-employment status and age. Married men are more frequently self-employed and are older than married women, both of which contribute to their greater wealth. The factor that contributes negatively to the gender wealth gap is tertiary education. Women are highly educated more frequently than men are, which makes their wealth higher. Accounting for this widens the unexplained part of the gender wealth gap. The total contribution of characteristics is positive and statistically significant, indicating that married women have characteristics that are less beneficial for contributing to wealth accumulation than those of than married men are, and this helps to explain a large part of their unconditional gender gap in wealth.

The same characteristics help to explain the gender gap for cohabiting partners and for married couples. Accounting for self-employment and age reduces the unexplained part of the gap, while taking tertiary education into account widens it. Additional factors that contribute positively to explaining the gap are income and having training in health. Men have higher incomes and are less frequently trained in health, and these both contribute positively to men having more wealth. Accounting for tenure widens the unexplained gap in the lower part of the wealth distribution.

Among households that have two adult members who are not partners or three or more adult members, the unexplained gender wealth gaps are negative and statistically significant for most of the middle part of the distribution (from $30^{\text {th }}$ quantile to $70^{\text {th }}$ quantile). The unconditional and conditional wealth gaps are quite similar for these households. Although there are differences in characteristics between men and women, some of them contribute positively and others negatively to explaining the gap. These positive and negative effects cancel each other out, so in total the explained part of the gap is never statistically significant (see Appendix 9).

The large gender wealth gap in partner-headed households has been identified by Sierminska et al. (2010) on the basis of German data. They find the raw gap to be larger for cohabiting couples than for married couples but they do not decompose the wealth gaps for different household types. Our results imply that although the raw gap is significantly in favour of men in married couples, this difference disappears when the observable characteristics such as age and being self-employed are accounted for.

Additionally, our findings point to problems with 50-50 splits in the imputation of individual-level wealth for married couples. Further investigation of the distribution of assets within a household reveals that men own more than $75 \%$ of within-household assets in $15 \%$ of married couples and women own more than $75 \%$ of within-household assets in only $8 \%$ of 
married couples. In order to capture wealth differences within a household, it is crucial to use individual-level wealth data.

To summarise, the unexplained gaps are insignificant for most of the quantiles or even throughout the entire wealth distribution for all types of households. On the few occasions when they are significant, they are not always in favour of men. For couple-headed households the raw gender gap is in favour of men, and more strongly so for married couples. For other types of households the raw gap is to a large extent in favour of women. Accounting for observable characteristics renders the unexplained parts of the gaps mostly or entirely insignificant. It appears that women in partner-headed households have characteristics that are worse for wealth accumulation than those of men, and accounting for this eliminates the gender wealth gap. In other types of household it is the other way around, as women have better characteristics than men do and taking this into account reduces the gaps in favour of women.

It is important to highlight that even when there is no unexplained gap for couples, the raw gap suggests that households do not pool their resources fully, as was also indicated by the earlier literature (Ashby and Burgoyne (2009)). If households were pooling all their resources, we would observe similar wealth structures for men and women despite their differences in income.

\subsection{Results by age groups}

To understand at which age the gender differences in wealth are the largest we estimate the raw and unexplained gaps in mean net wealth for different age groups. Given that women have longer life expectancy than men, they should save more for retirement. However, Chang (2010) provides evidence that pension wealth is smaller for women and we find the same for private pension wealth in this paper. Additionally, Chang (2010) argues that contrary to the stereotype that widows are wealthier as they inherit their husbands' wealth, the statistics show the opposite for the US, where elderly widows are worse off than elderly married couples.

Figure 4 presents the raw and unexplained gaps over the age groups. Like in our estimates over the wealth quantiles, the raw gender wealth gap has a U-shaped pattern over the age groups. The raw gap is positive for the youngest and the oldest age groups and insignificant in the middle. The unexplained gap also has a U-shaped pattern, and it is significantly positive for the youngest age group and negative for the 55-64 age group. It is surprising that the largest positive gap is among individuals aged below 35, where men in their 20s and early 30s have on average three times the wealth of women. Similarly, Chang (2010) points out that the wealth gap in the US is largest for men and women in their 20s and 30s and she explains it through a combination of several factors, such as differences in income levels and home ownership rates, and the burdens of single parenthood. As the young have had little time to accumulate assets, the gap reflects the different starting points for men and women. In cross-sectional data we cannot distinguish between age and cohort effects, so the question remains open whether the substantial difference in wealth between young men and women will disappear as they age or whether it shows a structural shift towards larger wealth gaps among the younger generation.

There is empirical evidence to support both of these possibilities. Grabka et al. (2015) show that the within-household wealth gap diminishes with age and that the wealth gap is smaller in 
households that were living in Eastern Germany. That implies that the high labour market participation rate of women that is characteristic of socialist countries can still affect the gender wealth gap of post-socialist economies, such as our sample country Estonia. The generous privatisation in the 1990s benefited all income groups similarly in Estonia, but it benefited much more the cohorts that were older than 60 at the time of the survey (Meriküll and Rõõm (2016)).

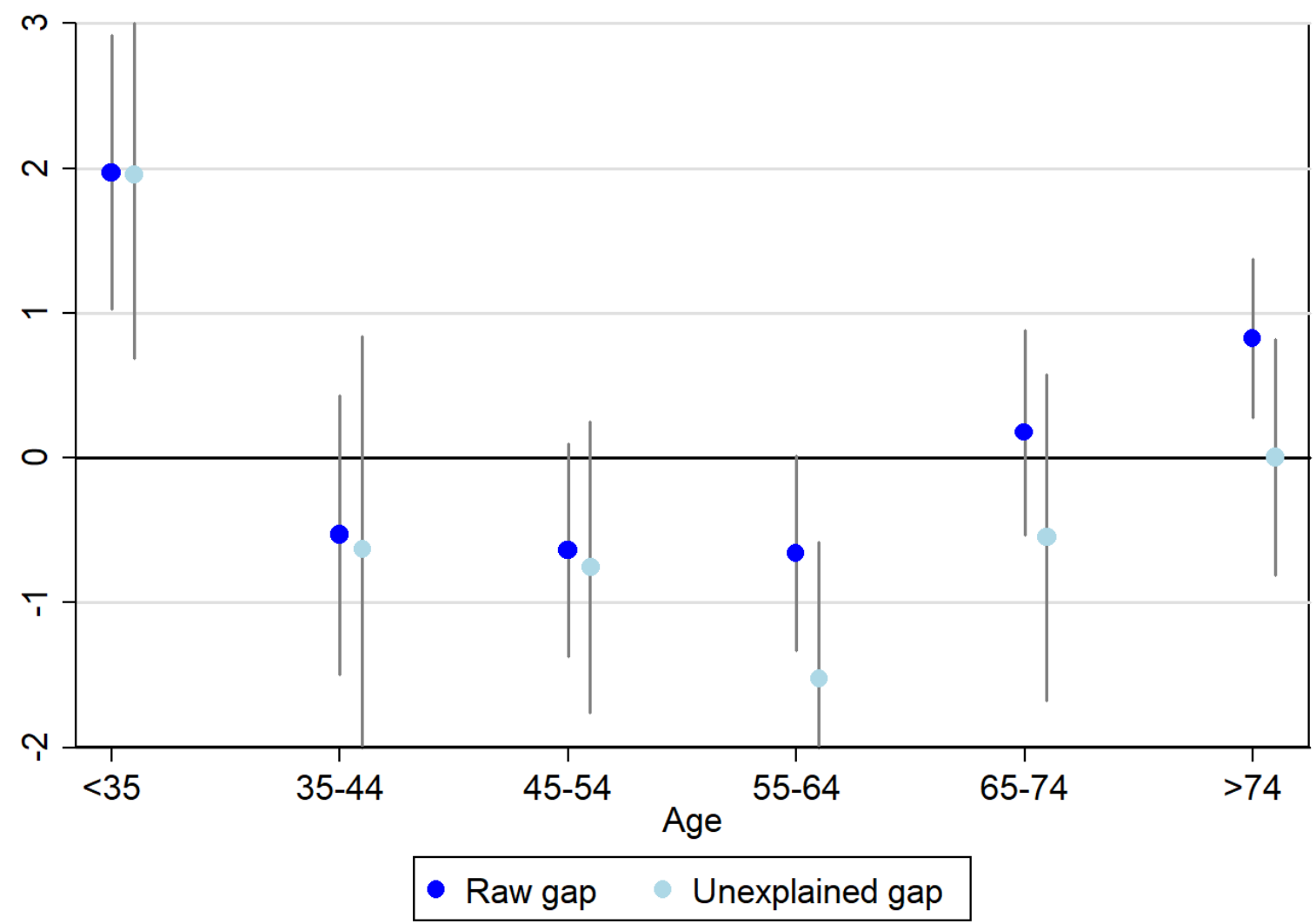

Figure 4: The gender wealth gaps across age groups, RIF based decomposition

Source: Authors' calculations from the Estonian HFCS.

Notes: The vertical scale refers to the difference between the IHS-transformed net wealth values for men and women. The wealth gaps are presented conditional on participation. Confidence bounds refer to statistical significance at $10 \%$.

As a consequence of the economic transition from socialism to capitalism, younger individuals are favoured in the Estonian labour market. This means that they have relatively high levels of income and wealth compared to their western counterparts. Women in Estonia are more likely to have completed higher education than men, which means that they start their working lives later and have had less time to accumulate wealth than men have. This difference matters most for the youngest age group and may explain why young men have substantially more wealth than women do. We can expect a structural shift towards a larger gender wealth gap in the future when the currently young cohorts age and more years pass from the egalitarian privatisation process. 


\section{Discussion: what is causing the differences in wealth accumulation between men and women?}

This paper has demonstrated that the unconditional gender gap in net wealth favours women in the lower part of the wealth distribution and men at the very top of the wealth distribution. The gap can be explained by the different characteristics of men and women and the unexplained gaps are statistically insignificant for all net wealth quantiles. However, the related literature has shown that there are large explained and unexplained gender wage gaps in Estonia that are in favour of men throughout the wage distribution (see e.g. Christofides et al. (2013)). This raises the question of why this substantial gender gap in wages does not transfer into the gender gap in wealth. This section considers this question and analyses the differences between men and women in some factors that contribute to wealth accumulation, such as income and consumption.

As shown in Section 2, the differences between the wealth functions of men and women may be caused by differences in inheritance or gifts received, in income, in consumption, or in the composition of wealth, which in turn is influenced by financial risk taking. In what follows, we discuss the relevance of each of these factors. The limitation of this analysis is that we have cross-sectional data, so we cannot observe income and consumption patterns in the past. Even so, if the differences in income and consumption habits between men and women are persistent in time, the current income and consumption gaps will be correlated with their past values and can shed light on the possible origins of the wealth gaps.

First, we look at the possible role of gifts and inheritances. The data for these items are backward-looking in the HFCS, so we can learn about gifts and inheritances received in the past. There is no tradition in Estonia of discriminating between heirs by their gender. The Estonian Household Finance and Consumption Survey collects data about inheritances and gifts at the household level, and the estimates show that in single-adult households there are no statistically significant differences between men and women in inheriting the household main residence or receiving it as a gift, or in getting any other valuable gifts or inheritances (the estimations are available upon request).

The composition of wealth is different in Estonia for different genders, as men hold more of their wealth in the form of risky assets, such as self-employment business assets, stocks and pension funds, whereas women's asset holdings mostly consist of deposits and real estate. Since men hold riskier assets, they tend to accumulate more wealth, because return is positively related with risk in the long term. Risk tolerance has proven to be one of the factors that determine the different investment strategies of men and women (see e.g. Almenberg and Dreber (2015)). We tested the role of risk-taking in explaining the gender gap for various wealth items and found that the differences in financial asset holdings cannot be explained by differences in the observed risk aversion of men and women. So either our risk aversion variable is a poor proxy of actual risk aversion or there may be other factors such as financial literacy (see e.g. Lusardi and Mitchell (2008)) that lead men to invest more in stocks and women to accumulate more deposits. 
Next, we analyse the gender-based differences in income. Figure 5 presents the gender gap in gross income over its distribution and includes all components of income: wage income, selfemployment income, capital gains, pensions, and transfers. The gender pay gap is usually estimated for wages but we estimate the gap for total income, including those who have no wage income. The pattern of the raw gender income gap over the distribution is similar to that for the gender gap in net wealth, as it is in favour of women in the lower part of the distribution where social transfers are the most important part of the income and in favour of men in the upper part of the distribution where wages contribute the most to disposable income.

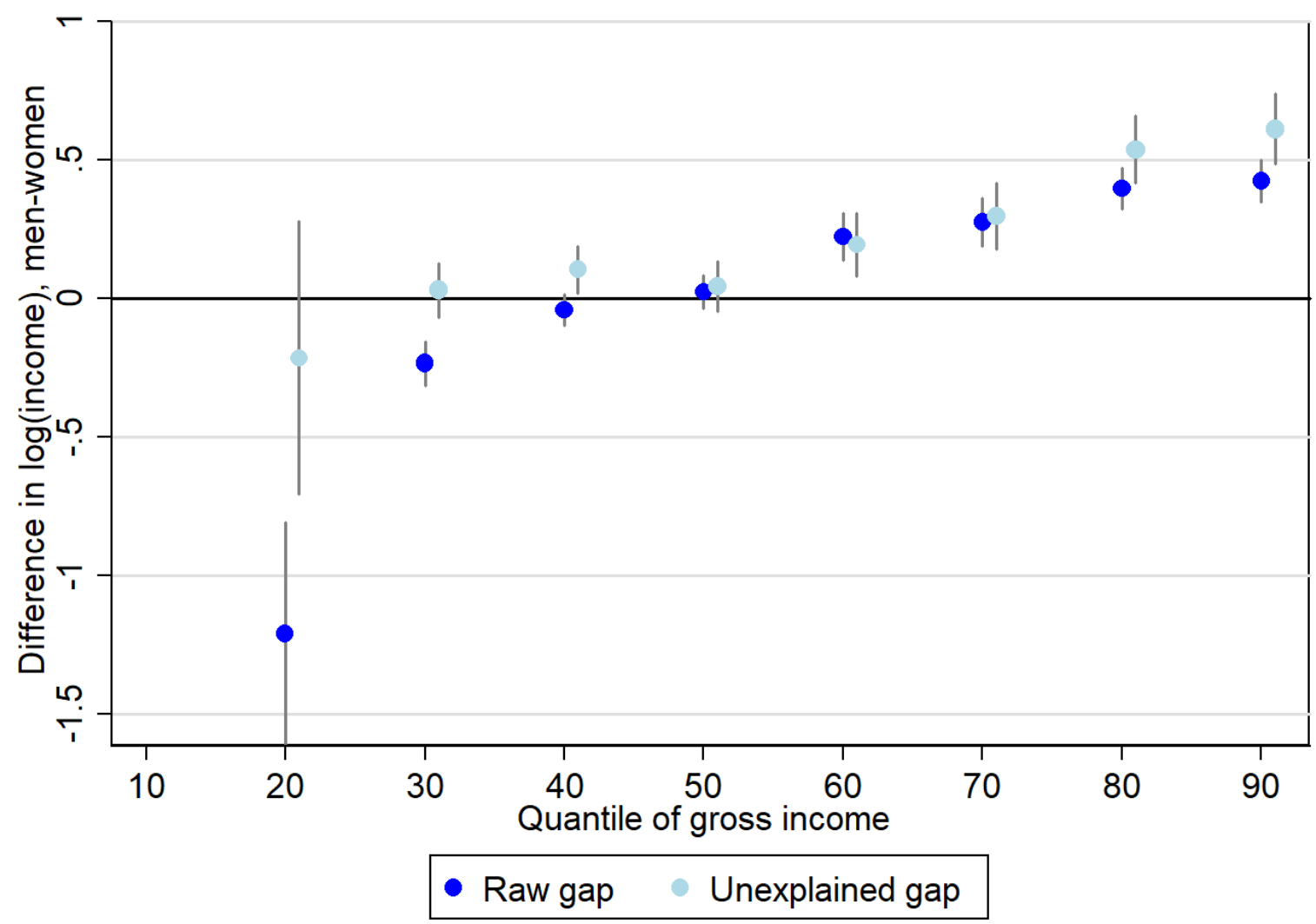

Figure 5: The gender gap in quantiles of gross income, RIF based decomposition

Source: Authors' calculations from the Estonian HFCS.

Note: The results for the $10^{\text {th }}$ quantile have not been calculated as men have zero income at that quantile. The gap is strongly in favour of women there, although the level of income is very low. Confidence bounds refer to statistical significance at $10 \%$.

Comparing Figures 5 and 1 implies that the raw gaps are much more often statistically significant and more persistently in favour of men for income than for net wealth. In the $90^{\text {th }}$ quantile the raw gender income gap is close to $50 \%$ while the gender wealth gap is below $20 \%$. The difference between unexplained gaps is even more pronounced. While the unexplained gaps for net wealth are never significant at the 95\% level, the unexplained gaps for income are 
positive and large in magnitude throughout the upper half of the income distribution. This suggests that while there is a tendency for the gender gap in income to be transferred to the gender gap in wealth, women seem to accumulate wealth better than men do, given their level of income. This finding suggests that women either save more relative to their income or benefit from the intra-household division of assets. To understand the differences in saving patterns, we investigate differences in the propensity to consume across income deciles.

Figure 6 presents the unconditional propensities to consume across income deciles for men and women. Unfortunately, we can only observe the individual-level consumption for singlemember households as the consumption data are not covered by registers and are collected at the household level by the survey. The figure demonstrates that there is hardly any difference in the propensities to consume for men and women within the same income groups ${ }^{10}$. Given that the propensities to consume are quite similar for both genders, the saving patterns for men and women are not systematically different across income deciles. This suggests that the smaller gender gap in net wealth than in gross income can to some extent be assigned to an intrahousehold division of assets that favours women more than the formal labour market characteristics would predict. In Subsection 4.2 we showed that although men own more riskier financial assets and self-employment assets that have a larger asset-building capacity, there is a smaller wealth gap in real estate holdings, which is the main wealth component in upper net wealth deciles. Owning real estate mostly as joint property apparently has an equalising effect.

${ }^{10}$ We could not provide the estimates on the gender gap in savings because there was very little variation in savings. As much as $60 \%$ of men and women reported that their expenses were about the same as their income. 


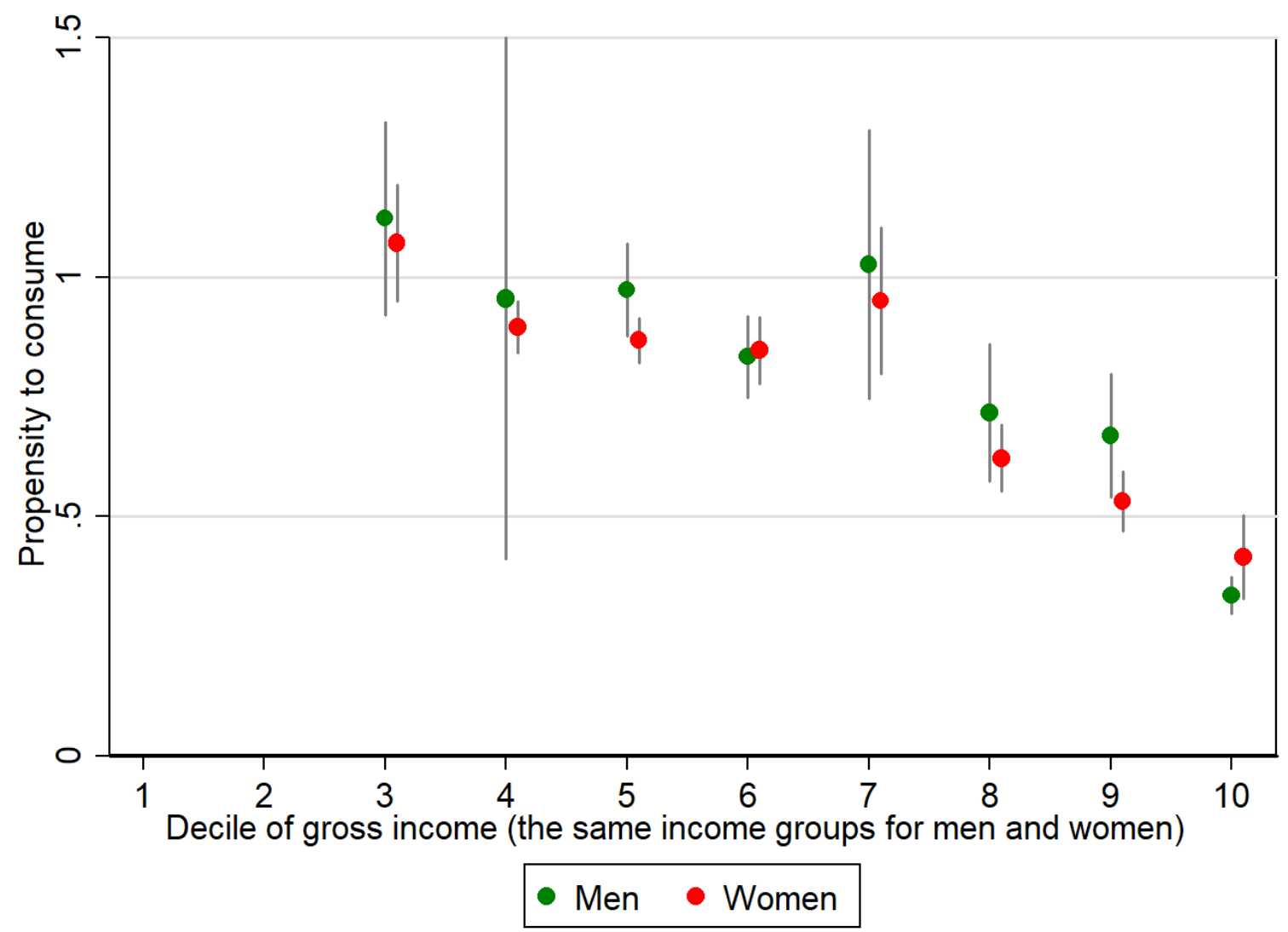

Figure 6: The propensity to consume, single-member households

Source: Authors' calculations from the Estonian HFCS.

Notes: The propensity to consume is measured as the sum of consumption of all consumer goods and services divided by income. The deciles of gross income are compiled taking into account the income of both men and women. The results for the first and the second decile are not reported because of the zero or very low income levels. The confidence bounds show statistical significance at $10 \%$.

\section{Conclusion}

The current paper studies the gender wealth gap in Estonia, the country that has the widest gender wage gap in Europe. The novelty of the paper is that it uses administrative individuallevel data on wealth that are linked to the Estonian Household Finance and Consumption Survey dataset from 2013. Administrative data are of better quality than survey data since they are much less prone to measurement error and are free of problems associated with item and unit non-response. We estimate the gaps in the mean levels and across quantiles of net wealth. The contribution of the paper is to provide a comprehensive analysis of the gender wealth gap as the gap is decomposed over the wealth quantiles and for different household types, for various net wealth components (real estate, business wealth, loans, etc.) and for different age groups.

To estimate the gender wealth gaps over the wealth quantiles we apply the method of unconditional quantile regressions, which is based on the recentered influence function (RIF), developed by Firpo et al. (2009). We use an Oaxaca-Blinder decomposition based on RIF 
regressions for men and women to decompose the total wealth gaps into their explained and unexplained parts at a particular quantile.

It is found that the unconditional gap in mean net wealth is $45 \%$ in Estonia. This gap is relatively sizeable in comparison with the gaps in other countries for which similar estimations have been performed, as it is of the same magnitude as the gap in Germany but considerably wider than the estimated gaps in Italy and France. However, the results may not be directly comparable since the findings for Estonia are based on administrative data, rather than on the survey data that the earlier studies used. Empirical evidence suggests that the survey-based assessments of the gender gaps in net wealth can be overestimated.

Although the gap in mean net wealth in Estonia is sizeable, there are no gender-based differences in wealth across most of the lower part of the net wealth distribution. The sharp differences in wealth among the richest men and women are the source of the large gap in mean net wealth in favour of men. Similarly, the unexplained wealth gaps that remain after controlling for various characteristics of men and women (such as differences in labour market status, education or income) are statistically insignificant throughout the net wealth distribution. The main explanatory variable that explains the difference in net wealth between the richest men and women is self-employment business wealth, since men are much more likely to have business assets and those assets are an important source of wealth.

We find significant differences in how men and women accumulate financial assets. Women save more in deposits and men more in riskier financial assets such as stocks and bonds and voluntary pension schemes. These differences in investment behaviour cannot be explained by observable characteristics. The findings may partly explain why men have more wealth in Estonia, since riskier financial assets provide better long-term returns.

Interesting results emerge when we look at the differences in net wealth between various household types. There is no significant gender-based difference in unconditional mean net wealth among single-member households, but the raw gap is strongly in favour of men for partner-headed households. Controlling for the observable characteristics of men and women renders the unexplained parts of the gender gap insignificant. It appears that women in partnerheaded households have characteristics that are worse for wealth accumulation than those of men, and accounting for this eliminates the gender wealth gap. In other types of household it is the other way around, as women have better characteristics than men do and taking this into account reduces the gaps in favour of women.

When we compare the gender gaps in wealth and income, we find that the pattern of the unconditional gender income gap is similar to that for the gender wealth gap over the distribution but it is more strongly in favour of men for income than for net wealth. Women seem to accumulate wealth better than men do, given their level of income. The propensities to consume are very similar for men and women, implying that the saving patterns are not systematically different between genders. This suggests that the insignificance of the unexplained gender gap in net wealth can to some extent be assigned to an intra-household division of assets that favours women more than the formal labour market characteristics would predict. However, as the raw wealth gap in partner-headed households is still present, implying that wealth accumulation is uneven, there does not seem to be full pooling within households. 
The upshot of our analysis is that women do much better than men in terms of wealth than in terms of income in a country where there is a large unexplained gender gap in wages. The intra-household sharing of resources seems to alleviate the large income gap to some extent, and real estate is an important equaliser of wealth. Although we observe wealth gaps within some risky asset components, total wealth is more equally distributed. Conditional on the observed characteristics, the unexplained wealth gaps are insignificant throughout the net wealth distribution. 


\section{References}

Alesina, A. F., Lotti, F., Mistrulli, P. E. (2013): Do women pay more for credit? Evidence from Italy, Journal of the European Economic Association, 11(S1), pp. 45-66.

Almenberg, J., Dreber, A. (2015): Gender, stock market participation and financial literacy. Economics Letters, 137, pp. 140-142.

Ashby, K. J., Burgoyne, C. B. (2009): The financial practices and perceptions behind separate systems of household financial management. The Journal of Socio-Economics, 38(3), pp. 519-529.

Bajtelsmit, V., Bernasek, A. (1996): Why do women invest differently than men? Financial Counselling and Planning, 7, pp. 1-10.

Blau, F. D., Kahn, L. M. (2000): Gender differences in pay. Journal of Economic Perspectives, 14(4), pp. 75-99.

Bonke, J. (2015): Pooling of income and sharing of consumption within households. Review of Economics of the Household, 13(1), pp. 73-93.

Bonnet, C., Keogh, A., Rapoport, B. (2013): How can we explain the gender wealth gap in France? INED documents de travail, no 191.

Bonthieux, S., Meurs, D. (2015): Gender Inequality. In: Atkinson, A.; Bourguignon, F. (Eds.) Handbook of Income Distribution, Vol 2, Great Britain: North Holland, pp. 981-1146.

Chang, M. L. (2010): Shortchanged: Why women have less wealth and what can be done about it. Oxford University Press.

Chen, H., Volpe, R. P. (2002): Gender differences in personal financial literacy among college students. Financial services review, 11(3), pp. 289-307.

Christofides, L. N., Polycarpou, A., Vrachimis, K. (2013): Gender wage gaps, 'sticky floors' and 'glass ceilings' in Europe. Labour Economics, 21, pp. 86-102.

D’Alessio, G. (2018): Gender wealth gap in Italy. Banca D’Italia Occasional Papers, No 433.

Dolado, J., Fergueroso, F., Jimeno, J. (2002): Recent Trends in Occupational Segregation by Gender: A Look Across the Atlantic. Universidad Carlos III de Madrid Working Paper 02-30.

Doss, C. R. (2013): Intrahousehold Bargaining and Resource Allocation in Developing Countries. World Bank Research Observer, 28(1), pp. 52-78.

Doss, C. R., Deere, C. D., Oduro, A. D., Swaminathan, H. (2014): The Gender Asset and Wealth Gaps. Development, 57(3-4), pp. 400-409.

Doss, C. R. (1996): Testing among Models of Intrahousehold Resource Allocation. World Development, 24(10), pp. 1597-1609. 
Dinardo, J., Fortin, N. M., Lemieux, T. (1996): Labour market institutions and the distribution of wages, 1973-1992: A semiparametric approach. Econometrica, Vol. 64, No. 5, pp. 1001-1044.

Edlund, L., Kopczuk, W. (2009): Women, wealth and mobility. American Economic Review, 99(1), pp. 146-178.

Embrey, L., Fox, J. (1997): Gender differences in the investment decision-making process. Financial Counseling and Planning, 8(2), pp. 33-40.

Fessler, P., Schürz, M. (2018): Private Wealth Across European Countries: The Role of Income, Inheritance and the Welfare State. Journal of Human Development and Capabilities, pp. $1-29$.

Firpo, S., Fortin, N. M., Lemieux, T. (2009): Unconditional Quantile Regression. Econometrica, 77(3), pp. 953-973.

Fisher, P. J. (2010): Gender differences in personal saving behaviours. Journal of Financial Counseling and Planning Education, 21(1), pp. 14-24.

Fortin, N., Firpo, S. M., Lemieux, T. (2011): Decomposition Methods in Economics. In: Ashenfelter, O.; Card, D. (Eds) Handbook of Labor Economics, Vol 4a, Great Britain: North Holland, pp. 1-102.

Frick, J. R., Grabka, M. M., Sierminska, E. M. (2007): Representative wealth data for Germany from the German SOEP: The Impact of methodological decisions around imputation and the choice of the aggregation unit, DIW Discussion Paper no. 562, Berlin.

Grabka, M. M., Marcus, J., Sierminska, E. (2015): Wealth distribution within couples. Review of Economics of the Household, 13, pp. 459-486.

Grable, J. (2000): Financial risk tolerance and additional factors that affect risk taking in everyday money matters. Journal of Business and Psychology, 14, pp. 625-630.

Hallahan, T. A., Faff, R. W., Mckenzie, M. D. (2004): An empirical investigation of personal financial risk tolerance. Financial Services Review, 13, pp. 57-78.

Hinz, R. P., Mccarthy, D. D., Turner, J. A. (1997): Are women more conservative investors? Gender differences in participant-directed pension investments, In M. S. Gordon, O. S. Mitchell, \& M. M. Twinney (Eds.), Positioning Pensions for the Twenty-First Century. Philadelphia: University of Pennsylvania Press.

HFCN (2013): The Eurosystem Household Finance and Consumption Survey: Results from the first wave, ECB Statistics Paper Series, No 2/2013.

HFCN (2016): The Household Finance and Consumption Survey: methodological report for the second wave. ECB Statistics Paper Series, No 17/2016.

Jann, B. (2005): OAXACA8: Stata module to compute decompositions of outcome differentials. Statistical Software Components S450604, Boston College Department of Economics.

Jianakopolos, N. A., Bernasek, A. (1998): Are women more risk averse? Economic Inquiry, 36, pp. 620-630.

Koellinger, P., Minniti, M., Schade, C. (2013): Gender differences in entrepreneurial propensity. Oxford Bulletin of Economics and Statistics, 75(2), pp. 213-234. 
Lersch, P. M. (2017): The Marriage Wealth Premium Revisited: Gender Disparities and WithinIndividual Changes in Personal Wealth in Germany. Demography, 54, pp. 961-983.

Lundberg, S. J., Pollak, R. A., Wales, T. J. (1997): Do Husbands and Wives Pool Their Resources? Evidence from the United Kingdom Child Benefit. The Journal of Human Resources, 32(3), pp. 463-480.

Lusardi, A. (2008): Household saving behavior: The role of financial literacy, information, and financial education programs. National Bureau of Economic Research Working paper, No 13824.

Lusardi, A., Mitchell, O. S. (2008): Planning and Financial Literacy: How Do Women Fare? American Economic Review, 98(2), pp. 413-417.

Meriküll, J., Rõõm, T. (2016): The assets, liabilities and wealth of Estonian households: Results of the Household Finance and Consumption Survey. Bank of Estonia Occasional Paper Series, No. 3/2016.

Nelson, J. A. (2015): Are women really more risk-averse than men? A re-analysis of the literature using expanded methods. Journal of Economic Surveys, 29(3), pp. 566-585.

Pahl, J. (2008): Family finances, individualisation, spending patterns and access to credit. The Journal of Socio-Economics, 37(2), pp. 577-591.

Pence, K. M. (2006): The Role of Wealth Transformations: An Application to Estimating the Effect of Tax Incentives on Saving. Contributions to Economic Analysis \& Policy, 5(1), pp. 1-24.

Phipps, S. A., Burton, P. S. (1998): What's mine is yours? The influence of male and female incomes on patterns of household expenditure. Economica, 65(260), pp. 599-613.

Phipps, S., Woolley, F. (2008): Control over money and the savings decisions of Canadian households. The Journal of Socio-Economics, 37, pp. 592-611.

Ravazzini, L., Chesters, J. (2018): Inequality and Wealth: Comparing the Gender Wealth Gap in Switzerland and Australia. Feminist Economics, 24(4), pp. 83-107.

Riphahn, R. T., Serfling, O. (2005): Item non-response on income and wealth questions. Empirical Economics, 30(2), pp. 521-538.

Roine, J., Waldenström, D. (2009): Wealth Concentration over the Path of Development: Sweden, 1873-2006. The Scandinavian Journal of Economics, 111(1), pp. 151-187.

Sierminska, E. M., Frick, J. R., Grabka, M. M. (2010): Examining the gender wealth gap. Oxford Economic Papers, 62(4), pp. 669-690.

Schneebaum, A., Rehm, M., Mader, K. (2018): The gender wealth gap across European countries. The Review of Income and Wealth, 64(2), pp. 295-331.

Schmidt, L., Sevak, P. (2006): Gender, marriage and asset accumulation in the United States. Feminist Economics, 12(1-2), pp. 139-166.

Stephens, M., Ward-Batts, J. (2003): The impact of separate taxation on the intra-household allocation of assets: evidence from the UK. Journal of Public Economics, 88, pp. 19892007. 
Sunden, A. E., Surrette, B. J. (1998): Gender differences in the allocation of assets in retirement savings plans. American Economic Review, 88, pp. 207-211.

Ulker, A. (2009): Wealth Holdings and Portfolio Allocation of the Elderly: The Role of Marital History. Journal of Family and Economic Issues, 30, pp. 90-108.

Van Rooij, M., Lusardi, A., Alessie, R. (2011): Financial literacy and stock market participation. Journal of Financial Economics, 101(2), pp. 449-472.

Vermeulen, P. (2016): Estimating the Top Tail of the Wealth Distribution. American Economic Review: Papers \& Proceedings, 106(5), pp. 646-650.

Vermeulen, P. (2018): How fat is the top tail of the wealth distribution? The Review of Income and Wealth, 64(2), pp. 357-387.

Vogler, C., Brockmann, M., Wiggins, R. D. (2006): Intimate relationships and changing patterns of money management at the beginning of the twenty-first century. The British Journal of Sociology, 57(3), pp. 455-482.

Zagorsky, J. L. (2003): Husbands' and wives' view of the family finances. Journal of SocioEconomics, 32, pp. 127-146.

Zucman, G. (2014): Taxing across borders: Tracking personal wealth and corporate profits. Journal of Economic Perspectives, 28(4), pp. 121-148. 
Appendix 1: Structure of households in the individual and household level data, $\%$ of the sample

\begin{tabular}{lcc}
\hline & $\begin{array}{c}\text { Individual level } \\
\text { (adults only) }\end{array}$ & $\begin{array}{c}\text { Household } \\
\text { level }\end{array}$ \\
\hline Single, never married & 0.094 & 0.164 \\
Widow & 0.083 & 0.145 \\
Divorced & 0.056 & 0.097 \\
Married & 0.328 & 0.285 \\
Cohabiting & 0.168 & 0.146 \\
Other & 0.270 & 0.164 \\
\hline
\end{tabular}

Source: Authors' calculations from the Estonian HFCS. 
Appendix 2: The net wealth regressions, RIF estimates for $10^{\text {th }}$, to $90^{\text {th }}$ quantiles except the median

\begin{tabular}{|c|c|c|c|c|c|c|c|c|}
\hline & $10^{\text {th }}$ quantile & $20^{\text {th }}$ quantile & $30^{\text {th }}$ quantile & $40^{\text {th }}$ quantile & $60^{\text {th }}$ quantile & $\mathbf{7 0}^{\text {th }}$ quantile & $80^{\text {th }}$ quantile & $90^{\text {th }}$ quantile \\
\hline Men, base women & $\begin{array}{l}2.326^{* *} \\
(1.093)\end{array}$ & $\begin{array}{l}-0.761 \\
(1.003)\end{array}$ & $\begin{array}{c}-0.071 \\
(0.299)\end{array}$ & $\begin{array}{l}-0.019 \\
(0.145)\end{array}$ & $\begin{array}{c}0.022 \\
(0.080)\end{array}$ & $\begin{array}{c}0.040 \\
(0.071)\end{array}$ & $\begin{array}{l}0.141^{* *} \\
(0.067)\end{array}$ & $\begin{array}{l}0.152^{* *} \\
(0.069)\end{array}$ \\
\hline Status self-employed, base employee & $\begin{array}{l}5.026^{* *} \\
(1.980)\end{array}$ & $\begin{array}{l}3.957^{* * *} \\
(1.888)\end{array}$ & $\begin{array}{l}1.617^{* * * *} \\
(0.566)\end{array}$ & $\begin{array}{l}1.042^{* * * *} \\
(0.278)\end{array}$ & $\begin{array}{l}0.872^{* * * *} \\
(0.165)\end{array}$ & $\begin{array}{c}0.912^{* * * *} \\
(0.156)\end{array}$ & $\begin{array}{l}1.071^{* * * *} \\
(0.159)\end{array}$ & $\begin{array}{l}1.176^{* * * *} \\
(0.190)\end{array}$ \\
\hline Status unemployed, base employee & $\begin{array}{c}1.491 \\
(2.248)\end{array}$ & $\begin{array}{c}-6.517^{* * * *} \\
(2.270)\end{array}$ & $\begin{array}{c}-1.423^{* *} \\
(0.662)\end{array}$ & $\begin{array}{c}-0.728^{* * *} \\
(0.309)\end{array}$ & $\begin{array}{l}-0.141 \\
(0.154)\end{array}$ & $\begin{array}{c}0.008 \\
(0.127)\end{array}$ & $\begin{array}{c}0.060 \\
(0.123)\end{array}$ & $\begin{array}{c}0.180 \\
(0.137)\end{array}$ \\
\hline Status student, base employee & $\begin{array}{c}1.727 \\
(5.315)\end{array}$ & $\begin{array}{l}-1.177 \\
(4.371)\end{array}$ & $\begin{array}{c}-2.484^{* *} \\
(0.989)\end{array}$ & $\begin{array}{l}-0.507 \\
(0.398)\end{array}$ & $\begin{array}{c}0.166 \\
(0.194)\end{array}$ & $\begin{array}{l}0.327^{* *} \\
(0.147)\end{array}$ & $\begin{array}{c}0.378^{* * * *} \\
(0.132)\end{array}$ & $\begin{array}{c}0.439^{* * * *} \\
(0.141)\end{array}$ \\
\hline Status retiree, base employee & $\begin{array}{l}-2.123 \\
(1.392)\end{array}$ & $\begin{array}{c}-3.444^{* *} \\
(1.528)\end{array}$ & $\begin{array}{c}-1.240^{* *} \\
(0.530)\end{array}$ & $\begin{array}{c}-0.635^{* *} \\
(0.277)\end{array}$ & $\begin{array}{c}-0.441^{* * * *} \\
(0.167)\end{array}$ & $\begin{array}{c}-0.532^{* * * *} \\
(0.155)\end{array}$ & $\begin{array}{c}-0.420^{* * * *} \\
(0.149)\end{array}$ & $\begin{array}{c}-0.332^{* *} \\
(0.157)\end{array}$ \\
\hline Status disabled, base employee & $\begin{array}{c}2.169 \\
(2.083)\end{array}$ & $\begin{array}{c}-9.367^{* * * *} \\
(2.344)\end{array}$ & $\begin{array}{c}-2.408^{* * * *} \\
(0.679)\end{array}$ & $\begin{array}{c}-1.242^{* * * *} \\
(0.332)\end{array}$ & $\begin{array}{c}-0.333^{*} \\
(0.185)\end{array}$ & $\begin{array}{l}-0.222 \\
(0.157)\end{array}$ & $\begin{array}{l}-0.126 \\
(0.147)\end{array}$ & $\begin{array}{c}0.142 \\
(0.152)\end{array}$ \\
\hline Status performing domestic tasks, base employee & $\begin{array}{l}5.214^{*} \\
(2.959)\end{array}$ & $\begin{array}{l}-4.210 \\
(2.665)\end{array}$ & $\begin{array}{l}-1.141 \\
(0.760)\end{array}$ & $\begin{array}{l}-0.448 \\
(0.354)\end{array}$ & $\begin{array}{l}-0.256 \\
(0.166)\end{array}$ & $\begin{array}{c}0.001 \\
(0.146)\end{array}$ & $\begin{array}{c}0.130 \\
(0.143)\end{array}$ & $\begin{array}{l}0.426^{* * * *} \\
(0.161)\end{array}$ \\
\hline Status other non-active, base employee & $\begin{array}{l}9.272^{* * *} \\
(3.669)\end{array}$ & $\begin{array}{l}10.096^{*} \\
(5.859)\end{array}$ & $\begin{array}{l}4.201^{*} \\
(2.434)\end{array}$ & $\begin{array}{c}0.392 \\
(0.952)\end{array}$ & $\begin{array}{l}-0.129 \\
(0.829)\end{array}$ & $\begin{array}{c}0.399 \\
(0.807)\end{array}$ & $\begin{array}{c}0.943 \\
(0.983)\end{array}$ & $\begin{array}{c}0.596 \\
(1.202)\end{array}$ \\
\hline Time in employment & $\begin{array}{l}-0.157 \\
(0.101)\end{array}$ & $\begin{array}{c}0.008 \\
(0.118)\end{array}$ & $\begin{array}{c}0.024 \\
(0.041)\end{array}$ & $\begin{array}{c}0.006 \\
(0.021)\end{array}$ & $\begin{array}{c}0.000 \\
(0.012)\end{array}$ & $\begin{array}{l}-0.005 \\
(0.011)\end{array}$ & $\begin{array}{l}-0.015 \\
(0.009)\end{array}$ & $\begin{array}{l}-0.007 \\
(0.009)\end{array}$ \\
\hline Time in employment squared / 100 & $\begin{array}{l}0.311^{*} \\
(0.177)\end{array}$ & $\begin{array}{c}0.131 \\
(0.205)\end{array}$ & $\begin{array}{l}-0.005 \\
(0.078)\end{array}$ & $\begin{array}{c}0.022 \\
(0.040)\end{array}$ & $\begin{array}{c}0.022 \\
(0.023)\end{array}$ & $\begin{array}{c}0.027 \\
(0.021)\end{array}$ & $\begin{array}{c}0.056^{* * * *} \\
(0.019)\end{array}$ & $\begin{array}{l}0.039^{* * *} \\
(0.019)\end{array}$ \\
\hline Income, thousand EUR & $\begin{array}{c}-0.103^{*} \\
(0.053)\end{array}$ & $\begin{array}{l}0.092^{* * *} \\
(0.041)\end{array}$ & $\begin{array}{c}0.054^{* * * *} \\
(0.013)\end{array}$ & $\begin{array}{l}0.033^{* * * *} \\
(0.007)\end{array}$ & $\begin{array}{l}0.025^{* * * *} \\
(0.004)\end{array}$ & $\begin{array}{c}0.028^{* * * *} \\
(0.004)\end{array}$ & $\begin{array}{c}0.030^{* * * *} \\
(0.004)\end{array}$ & $\begin{array}{l}0.036^{* * *} \\
(0.005)\end{array}$ \\
\hline Income squared $/ 100$ & $\begin{array}{l}0.002^{* * *} \\
(0.001)\end{array}$ & $\begin{array}{c}-0.002^{* * *} \\
(0.001)\end{array}$ & $\begin{array}{c}-0.001^{* * * *} \\
(0.000)\end{array}$ & $\begin{array}{c}-0.001^{* * * *} \\
(0.000)\end{array}$ & $\begin{array}{c}-0.000^{* * * *} \\
(0.000)\end{array}$ & $\begin{array}{c}-0.000^{* * *} \\
(0.000)\end{array}$ & $\begin{array}{c}-0.001^{* * *} \\
(0.000)\end{array}$ & $\begin{array}{c}-0.001^{* * * *} \\
(0.000)\end{array}$ \\
\hline Secondary education, base primary & $\begin{array}{l}-2.169 \\
(1.630)\end{array}$ & $\begin{array}{l}3.836^{* *} \\
(1.557)\end{array}$ & $\begin{array}{l}1.176^{* * *} \\
(0.468)\end{array}$ & $\begin{array}{c}0.918^{* * * *} \\
(0.228)\end{array}$ & $\begin{array}{c}0.495^{* * * *} \\
(0.116)\end{array}$ & $\begin{array}{c}0.328^{* * * *} \\
(0.103)\end{array}$ & $\begin{array}{c}0.165^{*} \\
(0.093)\end{array}$ & $\begin{array}{l}0.207^{* *} \\
(0.084)\end{array}$ \\
\hline Tertiary education, base primary & $\begin{array}{l}-0.966 \\
(2.002)\end{array}$ & $\begin{array}{l}6.012^{* * * *} \\
(1.926)\end{array}$ & $\begin{array}{c}2.100^{* * * *} \\
(0.597)\end{array}$ & $\begin{array}{l}1.492^{* * * *} \\
(0.303)\end{array}$ & $\begin{array}{c}0.938^{* * * *} \\
(0.167)\end{array}$ & $\begin{array}{c}0.665^{* * * *} \\
(0.148)\end{array}$ & $\begin{array}{c}0.538^{* * * *} \\
(0.138)\end{array}$ & $\begin{array}{c}0.546^{* * * *} \\
(0.123)\end{array}$ \\
\hline Training in education, base general programmes & $\begin{array}{c}0.432 \\
(2.819)\end{array}$ & $\begin{array}{c}0.197 \\
(2.244)\end{array}$ & $\begin{array}{c}0.533 \\
(0.706)\end{array}$ & $\begin{array}{c}0.170 \\
(0.376)\end{array}$ & $\begin{array}{c}0.149 \\
(0.232)\end{array}$ & $\begin{array}{c}0.129 \\
(0.206)\end{array}$ & $\begin{array}{l}-0.090 \\
(0.198)\end{array}$ & $\begin{array}{c}-0.469^{* * * *} \\
(0.162)\end{array}$ \\
\hline Training in humanities, base general programmes & $\begin{array}{l}5.287^{* * *} \\
(2.614)\end{array}$ & $\begin{array}{c}3.084 \\
(2.257)\end{array}$ & $\begin{array}{c}0.960 \\
(0.748)\end{array}$ & $\begin{array}{c}0.185 \\
(0.383)\end{array}$ & $\begin{array}{c}0.021 \\
(0.247)\end{array}$ & $\begin{array}{c}0.090 \\
(0.210)\end{array}$ & $\begin{array}{c}0.181 \\
(0.204)\end{array}$ & $\begin{array}{c}0.257 \\
(0.217)\end{array}$ \\
\hline
\end{tabular}


Training in social sciences, base general programmes

Training in science, base general programmes

Training in engineering, base general programmes

Training in agriculture, base general programmes

Training in health, base general programmes

Training in services, base general programmes

Age

Age squared / 100

Immigrant, base born in Estonia

One child, base no children

Two children, base no children

Three children, base no children

Child under three years, base other

Marital status widow, base single/never married

Marital status divorced, base single/never married

Marital status married, base single/never married

Marital status cohabiting, base single/never married

Region north, base central Estonia

Region west, base central Estonia

Region south, base central Estonia

Region east, base central Estonia

\begin{tabular}{|c|c|c|c|}
\hline $4.149^{* *}$ & 2.628 & 0.581 & 0.103 \\
\hline (1.900) & (1.692) & $(0.524)$ & $(0.263)$ \\
\hline 5.103 & 4.521 & 1.079 & 0.014 \\
\hline$(4.077)$ & (3.294) & $(1.065)$ & $(0.529)$ \\
\hline $5.163^{* * * *}$ & $2.455^{*}$ & $0.991^{* * *}$ & 0.247 \\
\hline$(1.418)$ & (1.351) & $(0.419)$ & $(0.210)$ \\
\hline $3.855^{*}$ & 3.033 & $1.139^{*}$ & -0.013 \\
\hline (2.159) & $(2.075)$ & $(0.675)$ & $(0.362)$ \\
\hline-0.602 & 0.281 & 0.784 & 0.172 \\
\hline$(2.911)$ & $(2.353)$ & $(0.696)$ & $(0.376)$ \\
\hline 1.987 & 1.454 & 0.474 & 0.278 \\
\hline$(1.886)$ & $(1.726)$ & $(0.528)$ & $(0.257)$ \\
\hline $1.023^{* * * *}$ & $0.953^{* * * *}$ & $0.506^{* * * *}$ & $0.304^{* * * *}$ \\
\hline$(0.221)$ & $(0.226)$ & $(0.070)$ & $(0.035)$ \\
\hline$-0.529^{* * * *}$ & $-0.507^{* *}$ & $-0.358^{* * *}$ & $-0.225^{* * * *}$ \\
\hline$(0.183)$ & $(0.201)$ & $(0.066)$ & $(0.033)$ \\
\hline 0.793 & -1.092 & -0.506 & -0.206 \\
\hline (1.066) & $(1.221)$ & $(0.388)$ & (0.197) \\
\hline 0.932 & 1.225 & 0.158 & 0.016 \\
\hline (1.476) & $(1.271)$ & $(0.383)$ & $(0.185)$ \\
\hline 0.810 & 0.787 & 0.474 & 0.211 \\
\hline (1.717) & $(1.462)$ & $(0.441)$ & $(0.215)$ \\
\hline $4.239^{*}$ & $5.880^{* * * *}$ & $1.493^{* * *}$ & $0.776^{* *}$ \\
\hline$(2.414)$ & (2.089) & $(0.648)$ & $(0.330)$ \\
\hline-2.942 & -1.067 & 0.221 & $0.440^{*}$ \\
\hline$(2.011)$ & (1.619) & $(0.472)$ & $(0.236)$ \\
\hline-1.118 & -2.154 & 0.376 & 0.196 \\
\hline$(2.052)$ & $(2.216)$ & $(0.694)$ & $(0.351)$ \\
\hline$-3.824^{*}$ & -2.345 & -0.183 & 0.180 \\
\hline$(2.273)$ & $(2.171)$ & $(0.659)$ & $(0.321)$ \\
\hline-2.476 & 2.606 & $1.557^{\text {**** }}$ & $0.888^{* * * *}$ \\
\hline (1.986) & (1.803) & $(0.538)$ & $(0.260)$ \\
\hline-2.972 & -1.677 & -0.679 & -0.115 \\
\hline$(2.275)$ & (1.997) & $(0.576)$ & $(0.262)$ \\
\hline 0.826 & 2.139 & $0.946^{*}$ & $0.578^{* * *}$ \\
\hline$(1.825)$ & $(1.747)$ & $(0.554)$ & $(0.273)$ \\
\hline 0.304 & 0.064 & 0.289 & 0.333 \\
\hline$(1.836)$ & (1.795) & $(0.578)$ & $(0.282)$ \\
\hline-1.078 & -1.236 & -0.176 & 0.082 \\
\hline (1.688) & $(1.640)$ & $(0.535)$ & $(0.263)$ \\
\hline-0.694 & -1.148 & -0.633 & -0.382 \\
\hline
\end{tabular}

$\begin{array}{cccc}0.125 & 0.077 & 0.040 & -0.173 \\ (0.149) & (0.132) & (0.122) & (0.115) \\ -0.325 & -0.314 & -0.143 & 0.021 \\ (0.280) & (0.195) & (0.195) & (0.230) \\ 0.139 & 0.041 & 0.073 & -0.033 \\ (0.116) & (0.104) & (0.096) & (0.094) \\ 0.027 & -0.024 & 0.090 & 0.105 \\ (0.215) & (0.190) & (0.178) & (0.188) \\ 0.215 & 0.248 & 0.328 & 0.019 \\ (0.220) & (0.212) & (0.217) & (0.221) \\ 0.127 & 0.099 & 0.020 & -0.031 \\ (0.141) & (0.127) & (0.115) & (0.119) \\ 0.117^{* * *} & 0.088^{* * *} & 0.077^{* * *} & 0.044^{* * *} \\ (0.019) & (0.017) & (0.015) & (0.014) \\ -0.078^{* * *} & -0.050^{* * *} & -0.050^{* * *} & -0.025^{*} \\ (0.019) & (0.017) & (0.015) & (0.014) \\ -0.142 & -0.322^{* * *} & -0.441^{* * *} & -0.428^{* * * *} \\ (0.111) & (0.103) & (0.096) & (0.086) \\ -0.027 & 0.087 & 0.159^{*} & 0.125 \\ (0.101) & (0.091) & (0.087) & (0.087) \\ 0.069 & 0.093 & 0.030 & -0.024 \\ (0.118) & (0.107) & (0.104) & (0.106) \\ 0.157 & 0.357^{* *} & 0.462^{* * *} & 0.394^{* *} \\ (0.182) & (0.165) & (0.164) & (0.176) \\ 0.084 & -0.115 & -0.120 & -0.012 \\ (0.127) & (0.109) & (0.105) & (0.109) \\ -0.017 & -0.041 & 0.005 & 0.008 \\ (0.194) & (0.179) & (0.159) & (0.151) \\ -0.109 & 0.007 & 0.076 & -0.053 \\ (0.169) & (0.150) & (0.134) & (0.124) \\ 0.280^{* *} & 0.205^{*} & 0.192^{*} & 0.147 \\ (0.136) & (0.122) & (0.107) & (0.100) \\ -0.053 & 0.019 & 0.084 & 0.056 \\ (0.131) & (0.111) & (0.100) & (0.091) \\ 1.006^{* * *} & 1.042^{* * *} & 0.825^{* * *} & 0.524^{* * *} \\ (0.151) & (0.135) & (0.131) & (0.132) \\ 0.304^{*} & 0.325^{* *} & 0.315^{* * *} & 0.190^{*} \\ (0.156) & (0.130) & (0.120) & (0.114) \\ 0.165 & 0.250^{* * *} & 0.212^{* * *} & 0.114 \\ (0.139) & (0.114) & (0.102) & (0.094) \\ -0.735^{* * *} & -0.468^{* * *} & -0.249^{* *} & -0.099\end{array}$




\begin{tabular}{|c|c|c|c|c|c|c|c|c|}
\hline \multirow{3}{*}{ Other town, base capital town } & $(1.998)$ & $(2.007)$ & $(0.631)$ & $(0.310)$ & $(0.153)$ & $(0.118)$ & $(0.102)$ & $(0.090)$ \\
\hline & $3.420^{* *}$ & $3.809^{* * *}$ & $1.017^{* * *}$ & $0.423^{*}$ & 0.189 & 0.080 & 0.076 & -0.041 \\
\hline & $(1.677)$ & $(1.486)$ & $(0.456)$ & $(0.230)$ & $(0.135)$ & $(0.128)$ & $(0.126)$ & $(0.128)$ \\
\hline \multirow[t]{2}{*}{ Village, base capital town } & $2.599^{*}$ & 1.746 & 0.451 & 0.045 & 0.182 & 0.151 & $0.217^{*}$ & 0.092 \\
\hline & $(1.556)$ & $(1.345)$ & $(0.417)$ & $(0.210)$ & $(0.123)$ & $(0.119)$ & $(0.121)$ & $(0.126)$ \\
\hline$N$ & 4120 & 4120 & 4120 & 4120 & 4120 & 4120 & 4120 & 4120 \\
\hline adj. $R^{2}$ & 0.081 & 0.129 & 0.188 & 0.215 & 0.218 & 0.203 & 0.171 & 0.131 \\
\hline
\end{tabular}

Source: Authors' calculations from the Estonian HFCS.

Notes: Standard errors in parentheses. ${ }^{*},{ }^{* *},{ }^{* * *}$ refer to statistical significance at $10 \%, 5 \%$ and $1 \%$ level. 
Appendix 3: Results of the detailed decomposition of the gender wealth gaps over quantiles of net wealth

\begin{tabular}{|c|c|c|c|c|c|c|c|c|c|}
\hline & $\begin{array}{c}10^{\text {th }} \\
\text { quantile }\end{array}$ & $\begin{array}{c}20^{\text {th }} \\
\text { quantile }\end{array}$ & $\begin{array}{c}3^{\text {th }} \\
\text { quantile }\end{array}$ & $\begin{array}{c}\mathbf{4 0}^{\text {th }} \\
\text { quantile }\end{array}$ & $\begin{array}{c}5^{\text {th }} \\
\text { quantile }\end{array}$ & $\begin{array}{c}60^{\text {th }} \\
\text { quantile }\end{array}$ & $\begin{array}{c}\text { 70 }^{\text {th }} \\
\text { quantile }\end{array}$ & $\begin{array}{c}80^{\text {th }} \\
\text { quantile }\end{array}$ & $\begin{array}{c}90^{\text {th }} \\
\text { quantile }\end{array}$ \\
\hline \multirow{2}{*}{ The raw gap } & 0.506 & $-1.792 * *$ & -0.430 & -0.235 & -0.086 & -0.077 & -0.033 & 0.089 & $0.186 * * *$ \\
\hline & $(1.021)$ & $(0.872)$ & $(0.295)$ & $(0.146)$ & $(0.102)$ & $(0.084)$ & $(0.075)$ & $(0.071)$ & $(0.066)$ \\
\hline \multicolumn{10}{|l|}{ The explained gap } \\
\hline \multirow[t]{2}{*}{ Total } & -0.927 & -0.035 & 0.340 & 0.042 & 0.041 & -0.021 & -0.042 & -0.018 & $0.151^{*}$ \\
\hline & $(1.172)$ & $(0.875)$ & $(0.333)$ & $(0.165)$ & $(0.115)$ & $(0.102)$ & $(0.097)$ & $(0.099)$ & $(0.091)$ \\
\hline \multirow[t]{2}{*}{ Status self-employed, base employee } & $0.302^{* *}$ & 0.121 & $0.063^{*}$ & $0.049^{* * * *}$ & $0.045^{* * *}$ & $0.055^{* * *}$ & $0.056^{* * *}$ & $0.068^{* * * *}$ & $0.059^{* * *}$ \\
\hline & $(0.126)$ & $(0.109)$ & $(0.036)$ & $(0.019)$ & $(0.014)$ & $(0.013)$ & $(0.013)$ & $(0.015)$ & $(0.015)$ \\
\hline \multirow[t]{2}{*}{ Status unemployed, base employee } & 0.044 & $-0.253^{*}$ & $-0.091^{*}$ & -0.030 & -0.022 & -0.008 & -0.009 & -0.000 & 0.007 \\
\hline & $(0.161)$ & $(0.141)$ & $(0.048)$ & $(0.022)$ & $(0.014)$ & $(0.011)$ & $(0.008)$ & $(0.007)$ & $(0.006)$ \\
\hline \multirow[t]{2}{*}{ Status student, base employee } & 0.014 & -0.048 & 0.041 & 0.012 & 0.005 & 0.001 & -0.002 & -0.002 & -0.003 \\
\hline & $(0.089)$ & $(0.066)$ & $(0.028)$ & $(0.009)$ & $(0.005)$ & $(0.004)$ & $(0.004)$ & $(0.004)$ & $(0.002)$ \\
\hline \multirow[t]{2}{*}{ Status retiree, base employee } & 0.263 & 0.293 & 0.117 & 0.077 & $0.065^{*}$ & $0.074^{* * *}$ & $0.111^{* * * *}$ & $0.080^{* *}$ & 0.038 \\
\hline & $(0.308)$ & $(0.262)$ & $(0.102)$ & $(0.052)$ & $(0.038)$ & $(0.034)$ & $(0.032)$ & $(0.033)$ & $(0.033)$ \\
\hline \multirow[t]{2}{*}{ Status disabled, base employee } & 0.018 & $-0.233^{* *}$ & $-0.069^{* * *}$ & $-0.035^{* *}$ & $-0.017^{*}$ & -0.010 & -0.005 & 0.001 & 0.008 \\
\hline & $(0.082)$ & $(0.108)$ & $(0.034)$ & $(0.016)$ & $(0.009)$ & $(0.007)$ & $(0.006)$ & $(0.005)$ & $(0.006)$ \\
\hline \multirow[t]{2}{*}{ Status performing domestic tasks, base employee } & $-0.476^{* *}$ & 0.318 & $0.147^{*}$ & 0.035 & $0.057^{* *}$ & $0.031^{*}$ & 0.015 & 0.003 & -0.022 \\
\hline & $(0.195)$ & $(0.247)$ & $(0.081)$ & $(0.038)$ & $(0.023)$ & $(0.019)$ & $(0.017)$ & $(0.017)$ & $(0.020)$ \\
\hline \multirow[t]{2}{*}{ Status other non-active, base employee } & -0.007 & -0.008 & -0.004 & -0.003 & 0.001 & 0.000 & 0.000 & 0.000 & 0.000 \\
\hline & $(0.014)$ & $(0.015)$ & $(0.008)$ & $(0.006)$ & $(0.001)$ & $(0.001)$ & $(0.001)$ & $(0.001)$ & $(0.000)$ \\
\hline \multirow[t]{2}{*}{ Time in employment } & 0.521 & 0.149 & 0.100 & 0.031 & 0.027 & 0.047 & $0.073^{* *}$ & 0.048 & 0.005 \\
\hline & $(0.375)$ & $(0.300)$ & $(0.110)$ & $(0.056)$ & $(0.037)$ & $(0.034)$ & $(0.037)$ & $(0.031)$ & $(0.025)$ \\
\hline \multirow[t]{2}{*}{ Time in employment squared / 100} & $-0.662^{*}$ & -0.352 & -0.197 & -0.088 & -0.057 & $-0.077^{*}$ & $-0.108^{* *}$ & $-0.100^{* * *}$ & -0.045 \\
\hline & $(0.388)$ & $(0.313)$ & $(0.123)$ & $(0.064)$ & $(0.043)$ & $(0.040)$ & $(0.043)$ & $(0.041)$ & $(0.034)$ \\
\hline \multirow[t]{2}{*}{ Income, thousand EUR } & -0.313 & 0.152 & 0.094 & 0.055 & 0.046 & 0.059 & 0.066 & 0.067 & 0.079 \\
\hline & $(0.484)$ & $(0.272)$ & $(0.137)$ & $(0.077)$ & $(0.064)$ & $(0.078)$ & $(0.087)$ & $(0.089)$ & $(0.104)$ \\
\hline \multirow[t]{2}{*}{ Income squared /100 } & 0.042 & -0.020 & -0.012 & -0.007 & -0.006 & -0.008 & -0.008 & -0.009 & -0.010 \\
\hline & $(0.455)$ & $(0.244)$ & $(0.128)$ & $(0.073)$ & $(0.061)$ & $(0.076)$ & $(0.084)$ & $(0.086)$ & $(0.099)$ \\
\hline \multirow[t]{2}{*}{ Secondary education, base primary } & -0.167 & 0.369 & 0.131 & $0.108^{* * *}$ & $0.089^{* * *}$ & $0.058^{* *}$ & $0.048^{* *}$ & $0.044^{* * *}$ & 0.027 \\
\hline & $(0.396)$ & $(0.298)$ & $(0.102)$ & $(0.049)$ & $(0.033)$ & $(0.024)$ & $(0.021)$ & $(0.019)$ & $(0.017)$ \\
\hline \multirow[t]{2}{*}{ Tertiary education, base primary } & 0.142 & -0.312 & $-0.259^{*}$ & $-0.202^{* * * *}$ & $-0.215^{* * *}$ & $-0.142^{* * * *}$ & $-0.123^{* * *}$ & $-0.127^{* * * *}$ & $-0.074^{* *}$ \\
\hline & $(0.502)$ & $(0.375)$ & $(0.133)$ & $(0.068)$ & $(0.050)$ & $(0.039)$ & $(0.035)$ & $(0.033)$ & $(0.030)$ \\
\hline
\end{tabular}


Training in education, base general programmes

Training in humanities, base general programmes

Training in social sciences, base general programmes

Training in science, base general programmes

Training in engineering, base general programmes

Training in agriculture, base general programmes

Training in health, base general programmes

Training in services, base general programmes

Age

Age squared / 100

Immigrant, base born in Estonia

One child, base no children

Two children, base no children

Three children, base no children

Child under three years, base other

Marital status widow, base single/never married

Marital status divorced, base single/never married

Marital status married, base single/never married

Marital status cohabiting, base single/never married

Region north, base central Estonia

$\begin{array}{ccc}-0.467 & -0.418 & -0.044 \\ (0.430) & (0.286) & (0.141) \\ 0.020 & -0.056 & 0.010 \\ (0.165) & (0.101) & (0.036) \\ -0.545 & -0.318 & 0.014 \\ (0.497) & (0.376) & (0.126) \\ 0.027 & 0.022 & 0.008 \\ (0.056) & (0.045) & (0.016) \\ 1.513^{* * *} & 0.839^{* * *} & 0.290^{* *} \\ (0.414) & (0.319) & (0.113) \\ -0.101 & -0.103^{*} & -0.035^{*} \\ (0.069) & (0.059) & (0.021) \\ 0.032 & -0.073 & -0.056 \\ (0.658) & (0.322) & (0.098) \\ 0.209^{*} & 0.144 & 0.034 \\ (0.120) & (0.096) & (0.036) \\ -2.661 & -2.444 & -2.132^{* * *} \\ (1.799) & (1.576) & (0.610) \\ 0.914 & 1.031 & 1.752^{* * *} \\ (1.745) & (1.571) & (0.626) \\ -0.084 & -0.006 & 0.045 \\ (0.093) & (0.079) & (0.031) \\ -0.002 & -0.028 & -0.013 \\ (0.037) & (0.045) & (0.019) \\ -0.008 & -0.003 & 0.010 \\ (0.049) & (0.036) & (0.014) \\ 0.008 & 0.008 & 0.004 \\ (0.039) & (0.035) & (0.015) \\ -0.034 & -0.011 & -0.001 \\ (0.061) & (0.030) & (0.009) \\ 0.716 & 0.858 & 0.224 \\ (0.624) & (0.663) & (0.243) \\ 0.224 & 0.246 * & 0.057 \\ (0.161) & (0.147) & (0.046) \\ -0.238 & 0.213 & 0.166^{*} \\ (0.309) & (0.254) & (0.092) \\ -0.176 & -0.102 & -0.038 \\ (0.263) & (0.215) & (0.073) \\ -0.034 & -0.058 & -0.006 \\ (0.084) & (0.078) & (0.023) \\ \end{array}$

(0.084)
0.042

$(0.069)$

0.016

(0.018)

0.039

(0.058)

0.001

(0.005)

0.060

$(0.056)$

$-0.008$

(0.008)

$-0.036$

(0.047)

0.020

(0.018)

$-1.417^{\text {*** }}$

(0.322)

$1.205^{* * *}$

(0.332)

0.022

$(0.015)$

$-0.003$

(0.006)

0.005

$(0.007)$

$(0.007)$
0.001

(0.006)

0.002

0.002
$(0.005)$

0.076

$(0.121)$

0.023

0.023
$(0.022)$

$0.102^{* * *}$

(0.046)

$-0.014$

(0.034)

$-0.006$

(0.012)
0.040

$(0.045)$

$0.025^{*}$

(0.014)

$0.064^{*}$

(0.038)

$-0.000$

(0.004)

0.016

(0.038)

0.000

(0.006)

0.009

$(0.045)$

0.005

(0.013)

$-0.719^{* * *}$

(0.204)

$0.545^{* *}$

$(0.215)$

0.012

(0.010)

$-0.001$

(0.003)

0.003

(0.005)

0.001

(0.003)

0.001

(0.003)

0.045

0.080

0.017

(0.014)

$0.069^{* *}$

$0.031)$

$-0.007$

(0.022)

$-0.010$

(0.011)
0.034

(0.046)

0.014

(0.011)

0.034

(0.032)

$-0.000$

(0.003)

0.035

(0.031)

$-0.003$

(0.005)

$-0.040$

$(0.039)$

0.005

$(0.010)$

(0.173)

$0.439^{* * *}$

(0.186)

0.012

(0.008)

$-0.000$

(0.003)

0.003

(0.004)

0.001

$(0.003)$

$-0.001$

(0.003)

$-0.001$

(0.066)

0.013

(0.011)

$0.045^{*}$

(0.023)

0.005

(0.017)

$-0.011$

(0.010)
$-0.034$

(0.044)

0.005

(0.010)

0.022

(0.030)

$-0.001$

(0.003)

0.015

0.001

(0.005)

$-0.050$

$(0.040)$

$-0.002$

(0.009)

$-0.459^{* * *}$

(0.158)

$0.305^{*}$

(0.171)

0.012

(0.008)

$-0.001$

(0.003)

0.002

(0.004)

0.001

(0.003)

$-0.002$

(0.004)

$-0.006$

$(0.059)$

(0.009)

$0.044^{* * *}$

$(0.020)$

0.006

(0.014)

$-0.016$

(0.013)
$-0.019$

(0.047)

$-0.001$

(0.010)

0.018

(0.030)

$-0.000$

(0.002)

$-0.006$

$(0.026)$

$-0.001$

(0.005)

$-0.033$

(0.047)

$-0.009$

(0.009)

$-0.331^{*}$

$(0.140)$

0.235

(0.157)

0.015

$(0.008)$

$-0.002$

(0.003)

$-0.001$

$(0.003)$

0.001

$0.004)$

$-0.001$

(0.002)

0.037

0.059

0.009

(0.008)

0.008

(0.018)

$-0.001$

(0.013)

$-0.017$

(0.014)
0.037

(0.034)

(0.010)

0.023

(0.029)

0.000

(0.002)

0.011

$(0.025)$

$-0.005$

(0.006)

$(0.045)$

$-0.014$

(0.009)

$-0.117$

(0.134)

0.055

(0.160)

0.012

(0.007)

$-0.001$

$-0.001$

0.001

(0.004)

$-0.000$

(0.002)

0.033

(0.058)

0.006

(0.007)

0.007

(0.016)

0.007

(0.011)

$-0.019$

(0.015) 


\begin{tabular}{|c|c|c|c|c|c|c|c|c|c|}
\hline Region west, base central Estonia & $\begin{array}{c}0.002 \\
(0.039)\end{array}$ & $\begin{array}{c}0.005 \\
(0.032)\end{array}$ & $\begin{array}{l}-0.004 \\
(0.013)\end{array}$ & $\begin{array}{c}0.000 \\
(0.005)\end{array}$ & $\begin{array}{c}0.001 \\
(0.004)\end{array}$ & $\begin{array}{l}-0.000 \\
(0.003)\end{array}$ & $\begin{array}{c}0.001 \\
(0.003)\end{array}$ & $\begin{array}{c}0.002 \\
(0.004)\end{array}$ & $\begin{array}{c}0.003 \\
(0.005)\end{array}$ \\
\hline \multirow[t]{2}{*}{ Region south, base central Estonia } & -0.000 & -0.006 & 0.001 & -0.001 & -0.001 & 0.000 & -0.000 & -0.001 & -0.002 \\
\hline & $(0.042)$ & $(0.038)$ & $(0.012)$ & $(0.006)$ & $(0.004)$ & $(0.003)$ & $(0.003)$ & $(0.003)$ & $(0.005)$ \\
\hline \multirow[t]{2}{*}{ Region east, base central Estonia } & -0.002 & -0.013 & -0.029 & -0.006 & -0.016 & $-0.024^{*}$ & $-0.014^{*}$ & -0.009 & -0.003 \\
\hline & $(0.084)$ & $(0.071)$ & $(0.028)$ & $(0.012)$ & $(0.011)$ & $(0.013)$ & $(0.008)$ & $(0.006)$ & $(0.004)$ \\
\hline \multirow[t]{2}{*}{ Other town, base capital town } & 0.004 & 0.009 & 0.003 & -0.000 & 0.000 & -0.000 & 0.000 & 0.001 & 0.002 \\
\hline & $(0.046)$ & $(0.054)$ & (0.017) & $(0.006)$ & $(0.004)$ & (0.004) & $(0.003)$ & $(0.006)$ & (0.008) \\
\hline \multirow{2}{*}{ Village, base capital town } & 0.034 & 0.050 & 0.020 & -0.002 & 0.006 & 0.004 & 0.010 & 0.015 & 0.014 \\
\hline & $(0.071)$ & $(0.059)$ & $(0.022)$ & $(0.009)$ & $(0.007)$ & $(0.006)$ & $(0.008)$ & $(0.011)$ & $(0.010)$ \\
\hline \multicolumn{10}{|l|}{ The unexplained gap } \\
\hline \multirow[t]{2}{*}{ Total } & 1.433 & -1.757 & $-0.769^{*}$ & -0.276 & -0.128 & -0.056 & 0.010 & 0.107 & 0.036 \\
\hline & $(1.489)$ & $(1.184)$ & $(0.421)$ & $(0.204)$ & $(0.140)$ & $(0.122)$ & $(0.115)$ & $(0.117)$ & $(0.109)$ \\
\hline \multirow[t]{2}{*}{ Status self-employed, base employee } & 0.051 & -0.090 & -0.018 & 0.001 & 0.003 & 0.016 & $0.018^{*}$ & $0.024^{* * *}$ & 0.006 \\
\hline & $(0.131)$ & $(0.104)$ & $(0.033)$ & $(0.016)$ & $(0.011)$ & $(0.010)$ & $(0.010)$ & $(0.010)$ & $(0.011)$ \\
\hline \multirow[t]{2}{*}{ Status unemployed, base employee } & -0.101 & -0.040 & -0.059 & 0.008 & -0.013 & -0.007 & $-0.022^{* *}$ & -0.012 & -0.014 \\
\hline & $(0.207)$ & $(0.183)$ & $(0.057)$ & $(0.026)$ & $(0.017)$ & $(0.013)$ & $(0.011)$ & $(0.011)$ & $(0.013)$ \\
\hline \multirow[t]{2}{*}{ Status student, base employee } & -0.188 & 0.147 & $-0.102^{*}$ & -0.036 & -0.021 & -0.014 & -0.007 & -0.004 & -0.003 \\
\hline & $(0.312)$ & $(0.224)$ & $(0.061)$ & $(0.023)$ & $(0.015)$ & $(0.012)$ & $(0.011)$ & $(0.010)$ & $(0.005)$ \\
\hline \multirow[t]{2}{*}{ Status retiree, base employee } & 0.421 & 0.735 & 0.026 & -0.033 & -0.022 & -0.078 & $-0.182^{*}$ & -0.115 & 0.013 \\
\hline & $(1.004)$ & $(0.942)$ & $(0.344)$ & $(0.177)$ & $(0.130)$ & $(0.111)$ & $(0.102)$ & $(0.103)$ & $(0.105)$ \\
\hline \multirow[t]{2}{*}{ Status disabled, base employee } & -0.056 & -0.156 & -0.052 & -0.044 & -0.016 & -0.008 & -0.005 & 0.010 & 0.021 \\
\hline & $(0.205)$ & $(0.200)$ & $(0.063)$ & $(0.029)$ & $(0.020)$ & $(0.017)$ & $(0.014)$ & $(0.014)$ & $(0.014)$ \\
\hline \multirow[t]{2}{*}{ Status performing domestic tasks, base employee } & 0.194 & -0.325 & -0.157 & -0.030 & $-0.068^{* *}$ & -0.036 & -0.028 & -0.014 & 0.005 \\
\hline & $(0.304)$ & $(0.364)$ & $(0.114)$ & $(0.054)$ & $(0.032)$ & $(0.026)$ & $(0.024)$ & $(0.024)$ & $(0.028)$ \\
\hline \multirow[t]{2}{*}{ Status other non-active, base employee } & 0.012 & 0.017 & 0.008 & 0.006 & -0.003 & -0.001 & -0.002 & -0.002 & -0.001 \\
\hline & $(0.010)$ & $(0.012)$ & $(0.006)$ & $(0.004)$ & $(0.002)$ & $(0.002)$ & $(0.002)$ & $(0.002)$ & $(0.002)$ \\
\hline \multirow[t]{2}{*}{ Time in employment } & -6.948 & -6.031 & -2.273 & -1.014 & -0.702 & $-1.071^{*}$ & $-1.570^{* * *}$ & $-0.942^{*}$ & 0.244 \\
\hline & $(5.859)$ & $(5.754)$ & $(2.025)$ & $(1.038)$ & $(0.719)$ & $(0.594)$ & $(0.538)$ & $(0.502)$ & $(0.473)$ \\
\hline \multirow[t]{2}{*}{ Time in employment squared / 100} & 5.305 & 5.191 & $2.208^{*}$ & 0.982 & 0.586 & $0.779^{* *}$ & $1.176^{* * *}$ & $0.897^{* * *}$ & 0.126 \\
\hline & $(3.566)$ & $(3.444)$ & $(1.293)$ & $(0.672)$ & $(0.469)$ & $(0.393)$ & $(0.363)$ & $(0.351)$ & $(0.340)$ \\
\hline \multirow[t]{2}{*}{ Income, thousand EUR } & -0.898 & -0.265 & -0.215 & -0.088 & -0.050 & 0.030 & 0.034 & -0.001 & 0.017 \\
\hline & $(0.863)$ & $(0.582)$ & $(0.196)$ & $(0.094)$ & $(0.067)$ & $(0.061)$ & $(0.061)$ & $(0.059)$ & $(0.073)$ \\
\hline \multirow[t]{2}{*}{ Income squared /100 } & 0.130 & 0.036 & 0.031 & 0.013 & 0.007 & -0.005 & -0.005 & 0.001 & -0.001 \\
\hline & $(0.298)$ & $(0.161)$ & $(0.069)$ & $(0.031)$ & $(0.020)$ & $(0.017)$ & $(0.018)$ & $(0.015)$ & $(0.019)$ \\
\hline \multirow{2}{*}{ Secondary education, base primary } & 0.886 & -0.445 & -0.232 & -0.063 & 0.051 & -0.031 & -0.005 & 0.091 & 0.006 \\
\hline & $(1.541)$ & $(1.299)$ & $(0.416)$ & $(0.197)$ & $(0.136)$ & $(0.103)$ & $(0.092)$ & $(0.084)$ & $(0.073)$ \\
\hline \multirow[t]{2}{*}{ Tertiary education, base primary } & -0.278 & $-3.169^{* * *}$ & -0.337 & -0.006 & 0.181 & 0.022 & 0.103 & $0.230^{*}$ & 0.025 \\
\hline & $(1.795)$ & $(1.512)$ & $(0.496)$ & $(0.246)$ & $(0.174)$ & $(0.141)$ & $(0.126)$ & $(0.118)$ & $(0.106)$ \\
\hline Training in education, base general programmes & 0.690 & $0.738^{*}$ & 0.049 & 0.029 & 0.038 & 0.033 & 0.036 & 0.021 & -0.008 \\
\hline
\end{tabular}




\begin{tabular}{|c|c|c|c|c|c|c|c|c|c|}
\hline \multirow{3}{*}{ Training in humanities, base general programmes } & $(0.546)$ & $(0.381)$ & $(0.171)$ & $(0.085)$ & $(0.057)$ & $(0.056)$ & $(0.053)$ & $(0.057)$ & $(0.040)$ \\
\hline & -0.268 & 0.052 & -0.069 & -0.061 & $-0.061^{* * *}$ & -0.038 & -0.014 & -0.011 & -0.021 \\
\hline & $(0.341)$ & $(0.226)$ & $(0.080)$ & $(0.039)$ & $(0.029)$ & (0.024) & $(0.022)$ & $(0.021)$ & $(0.022)$ \\
\hline \multirow[t]{2}{*}{ Training in social sciences, base general programmes } & 0.361 & 0.279 & -0.089 & -0.125 & $-0.146^{*}$ & -0.083 & -0.051 & -0.061 & -0.025 \\
\hline & $(0.944)$ & $(0.746)$ & $(0.244)$ & $(0.115)$ & $(0.078)$ & $(0.065)$ & $(0.060)$ & $(0.058)$ & $(0.055)$ \\
\hline \multirow[t]{2}{*}{ Training in science, base general programmes } & 0.226 & $0.242^{*}$ & $0.089^{*}$ & 0.018 & 0.010 & 0.010 & -0.002 & -0.001 & 0.005 \\
\hline & $(0.181)$ & $(0.136)$ & $(0.046)$ & $(0.024)$ & $(0.017)$ & $(0.014)$ & $(0.010)$ & $(0.010)$ & $(0.010)$ \\
\hline \multirow[t]{2}{*}{ Training in engineering, base general programmes } & $0.831^{*}$ & $0.705^{*}$ & $0.210^{*}$ & -0.006 & -0.026 & 0.019 & 0.024 & -0.029 & 0.021 \\
\hline & $(0.446)$ & $(0.382)$ & $(0.125)$ & $(0.062)$ & $(0.044)$ & $(0.036)$ & $(0.032)$ & $(0.030)$ & $(0.028)$ \\
\hline \multirow[t]{2}{*}{ Training in agriculture, base general programmes } & 0.308 & $0.411^{* * *}$ & $0.121^{* * *}$ & 0.029 & 0.002 & 0.009 & -0.003 & -0.003 & 0.019 \\
\hline & $(0.209)$ & $(0.174)$ & $(0.060)$ & $(0.033)$ & $(0.024)$ & $(0.021)$ & $(0.019)$ & $(0.018)$ & $(0.020)$ \\
\hline \multirow[t]{2}{*}{ Training in health, base general programmes } & 0.138 & 0.264 & 0.055 & 0.023 & -0.019 & 0.035 & 0.042 & 0.011 & -0.031 \\
\hline & $(0.763)$ & $(0.404)$ & $(0.121)$ & $(0.059)$ & $(0.054)$ & $(0.046)$ & $(0.047)$ & $(0.054)$ & $(0.052)$ \\
\hline \multirow[t]{2}{*}{ Training in services, base general programmes } & 0.140 & 0.098 & 0.007 & 0.018 & -0.007 & -0.004 & -0.013 & $-0.030^{*}$ & -0.020 \\
\hline & $(0.268)$ & $(0.222)$ & $(0.070)$ & $(0.033)$ & $(0.024)$ & $(0.019)$ & $(0.017)$ & $(0.016)$ & $(0.015)$ \\
\hline \multirow[t]{2}{*}{ Age } & $-52.126^{* *}$ & $-52.324^{* *}$ & -10.123 & -0.090 & -2.143 & -0.536 & -0.167 & -0.251 & -2.213 \\
\hline & $(25.435)$ & $(22.760)$ & $(7.646)$ & $(3.744)$ & $(2.603)$ & $(2.153)$ & $(1.964)$ & $(1.768)$ & $(1.680)$ \\
\hline \multirow[t]{2}{*}{ Age squared / 100} & $22.565^{*}$ & $22.858^{*}$ & 4.172 & -0.085 & 1.031 & 0.209 & 0.117 & 0.104 & 0.985 \\
\hline & $(12.688)$ & $(11.957)$ & $(4.246)$ & $(2.138)$ & $(1.502)$ & $(1.256)$ & $(1.155)$ & $(1.053)$ & $(1.035)$ \\
\hline \multirow[t]{2}{*}{ Immigrant, base born in Estonia } & 0.311 & 0.262 & -0.158 & -0.071 & -0.046 & -0.036 & 0.015 & 0.011 & 0.049 \\
\hline & $(0.472)$ & $(0.451)$ & $(0.158)$ & $(0.077)$ & $(0.054)$ & $(0.044)$ & $(0.041)$ & $(0.039)$ & $(0.034)$ \\
\hline \multirow[t]{2}{*}{ One child, base no children } & -0.385 & $0.878^{*}$ & $0.392^{* *}$ & 0.090 & 0.017 & 0.001 & -0.002 & -0.001 & 0.024 \\
\hline & $(0.599)$ & $(0.473)$ & $(0.152)$ & $(0.073)$ & $(0.051)$ & $(0.042)$ & $(0.038)$ & $(0.037)$ & $(0.035)$ \\
\hline \multirow[t]{2}{*}{ Two children, base no children } & -0.259 & -0.076 & 0.036 & 0.016 & 0.013 & 0.024 & 0.007 & -0.012 & -0.019 \\
\hline & $(0.479)$ & $(0.376)$ & $(0.119)$ & $(0.058)$ & $(0.040)$ & $(0.033)$ & $(0.031)$ & $(0.029)$ & $(0.029)$ \\
\hline \multirow[t]{2}{*}{ Three children, base no children } & 0.116 & 0.009 & 0.054 & -0.005 & 0.003 & 0.012 & 0.005 & 0.011 & 0.004 \\
\hline & $(0.204)$ & $(0.162)$ & $(0.053)$ & $(0.026)$ & $(0.018)$ & $(0.015)$ & $(0.014)$ & $(0.014)$ & $(0.016)$ \\
\hline \multirow[t]{2}{*}{ Child under three years, base other } & -0.605 & -0.220 & -0.129 & -0.039 & -0.039 & $-0.054^{*}$ & -0.031 & -0.009 & -0.006 \\
\hline & $(0.497)$ & $(0.370)$ & $(0.114)$ & $(0.055)$ & $(0.039)$ & $(0.031)$ & $(0.027)$ & $(0.026)$ & $(0.025)$ \\
\hline \multirow[t]{2}{*}{ Marital status widow, base single/never married } & -0.663 & -1.042 & -0.380 & -0.195 & -0.062 & 0.021 & 0.015 & -0.061 & -0.043 \\
\hline & $(0.954)$ & $(0.986)$ & $(0.344)$ & $(0.171)$ & $(0.115)$ & $(0.095)$ & $(0.085)$ & $(0.084)$ & $(0.082)$ \\
\hline \multirow[t]{2}{*}{ Marital status divorced, base single/never married } & -0.520 & -0.918 & -0.284 & $-0.177^{*}$ & -0.079 & -0.050 & -0.048 & -0.057 & -0.028 \\
\hline & $(0.690)$ & $(0.609)$ & $(0.196)$ & $(0.094)$ & $(0.063)$ & $(0.049)$ & $(0.042)$ & $(0.039)$ & $(0.035)$ \\
\hline \multirow[t]{2}{*}{ Marital status married, base single/never married } & -0.147 & -0.037 & 0.226 & 0.140 & 0.186 & 0.141 & 0.142 & -0.049 & -0.017 \\
\hline & $(1.691)$ & $(1.403)$ & $(0.452)$ & $(0.216)$ & $(0.148)$ & $(0.115)$ & $(0.102)$ & $(0.094)$ & $(0.087)$ \\
\hline \multirow[t]{2}{*}{ Marital status cohabiting, base single/never married } & 0.547 & 0.423 & 0.126 & -0.006 & 0.009 & 0.002 & 0.008 & -0.022 & 0.017 \\
\hline & $(0.738)$ & $(0.588)$ & $(0.179)$ & $(0.081)$ & $(0.054)$ & $(0.042)$ & $(0.035)$ & $(0.032)$ & $(0.029)$ \\
\hline \multirow[t]{2}{*}{ Region north, base central Estonia } & 0.718 & 0.715 & -0.418 & -0.248 & $-0.299^{*}$ & $-0.366^{* * * *}$ & -0.197 & -0.019 & $0.240^{* *}$ \\
\hline & (1.731) & (1.509) & $(0.501)$ & $(0.244)$ & $(0.170)$ & $(0.140)$ & $(0.125)$ & $(0.124)$ & $(0.120)$ \\
\hline
\end{tabular}




\begin{tabular}{|c|c|c|c|c|c|c|c|c|c|}
\hline Region west, base central Estonia & $\begin{array}{c}0.066 \\
(0.421)\end{array}$ & $\begin{array}{c}0.068 \\
(0.368)\end{array}$ & $\begin{array}{l}-0.173 \\
(0.126)\end{array}$ & $\begin{array}{l}-0.045 \\
(0.060)\end{array}$ & $\begin{array}{l}-0.046 \\
(0.042)\end{array}$ & $\begin{array}{c}-0.062^{*} \\
(0.035)\end{array}$ & $\begin{array}{l}-0.025 \\
(0.029)\end{array}$ & $\begin{array}{l}-0.009 \\
(0.027)\end{array}$ & $\begin{array}{c}0.034 \\
(0.025)\end{array}$ \\
\hline \multirow[t]{2}{*}{ Region south, base central Estonia } & 0.618 & 0.955 & -0.007 & 0.020 & -0.006 & -0.079 & -0.071 & -0.038 & 0.068 \\
\hline & $(0.900)$ & $(0.798)$ & $(0.267)$ & $(0.130)$ & $(0.090)$ & $(0.071)$ & $(0.059)$ & $(0.054)$ & $(0.047)$ \\
\hline \multirow[t]{2}{*}{ Region east, base central Estonia } & 0.186 & 0.067 & -0.154 & 0.010 & -0.034 & $-0.065^{*}$ & -0.034 & -0.028 & -0.016 \\
\hline & $(0.479)$ & $(0.428)$ & $(0.142)$ & $(0.069)$ & $(0.047)$ & $(0.035)$ & $(0.027)$ & $(0.024)$ & $(0.020)$ \\
\hline \multirow[t]{2}{*}{ Other town, base capital town } & -1.385 & -0.645 & -0.036 & -0.216 & -0.142 & $-0.191^{*}$ & -0.026 & 0.109 & $0.289^{* * * *}$ \\
\hline & $(1.300)$ & $(1.044)$ & $(0.347)$ & $(0.171)$ & $(0.121)$ & $(0.102)$ & $(0.097)$ & $(0.097)$ & $(0.097)$ \\
\hline \multirow[t]{2}{*}{ Village, base capital town } & -0.535 & 0.222 & 0.238 & -0.045 & 0.015 & -0.004 & $0.127^{*}$ & $0.195^{* *}$ & $0.234^{* * *}$ \\
\hline & (1.011) & $(0.802)$ & $(0.266)$ & $(0.133)$ & $(0.095)$ & $(0.080)$ & $(0.077)$ & $(0.079)$ & $(0.083)$ \\
\hline \multirow[t]{2}{*}{ Constant } & $31.973^{* *}$ & $28.655^{\text {**** }}$ & $6.645^{* * *}$ & 1.049 & 1.771 & 1.402 & 0.650 & 0.175 & 0.051 \\
\hline & (13.701) & (10.895) & $(3.385)$ & $(1.561)$ & $(1.078)$ & $(0.881)$ & $(0.793)$ & $(0.711)$ & $(0.659)$ \\
\hline$N$ & 4120 & 4120 & 4120 & 4120 & 4120 & 4120 & 4120 & 4120 & 4120 \\
\hline
\end{tabular}

Source: Authors' calculations from the Estonian HFCS.

Notes: Standard errors in parentheses. ${ }^{*},{ }^{* *},{ }^{* * *}$ refer to statistical significance at $10 \%, 5 \%$ and $1 \%$ level. 
Appendix 4: Results of the decomposition of net wealth in monetary values

\begin{tabular}{lccccc}
\hline & $\begin{array}{c}\text { Wealth of men } \\
\text { in EUR }\end{array}$ & $\begin{array}{c}\text { Wealth of } \\
\text { women in EUR }\end{array}$ & \multicolumn{2}{c}{ Raw gap } & Unexplained \\
Difference in & Difference in & gap in EUR \\
$\%$ & & -291 & 119 & -40.9 & 512 \\
\hline $10^{\text {th }}$ quintile & -172 & 79 & 36 & 46.8 & 62 \\
$20^{\text {th }}$ quintile & 116 & 2275 & -794 & -34.9 & -1549 \\
$30^{\text {th }}$ quintile & 1481 & 8355 & $-1748^{*}$ & $-20.9 *$ & $-1967 *$ \\
$40^{\text {th }}$ quintile & 6607 & 16022 & -1332 & -8.3 & -1836 \\
$50^{\text {th }}$ quintile & 14689 & 26196 & -1938 & -7.4 & -1510 \\
$60^{\text {th }}$ quintile & 24254 & 39832 & -1282 & -3.2 & 67 \\
$70^{\text {th }}$ quintile & 38550 & 57350 & 5340 & 9.3 & 6283 \\
$80^{\text {th }}$ quintile & 62690 & 86602 & $17702^{* * *}$ & $20.4^{* * * *}$ & 5724 \\
$90^{\text {th }}$ quintile & 104304 & & & & \\
\hline
\end{tabular}

Source: Authors' calculations from the Estonian HFCS.

Notes: Standard errors in parentheses. ${ }^{*},{ }^{* *},{ }^{* * *}$ refer to statistical significance at $10 \%, 5 \%$ and $1 \%$ level. 


\section{Appendix 5: The gender gap in quantiles of different items of net wealth, controlling for risk aversion}
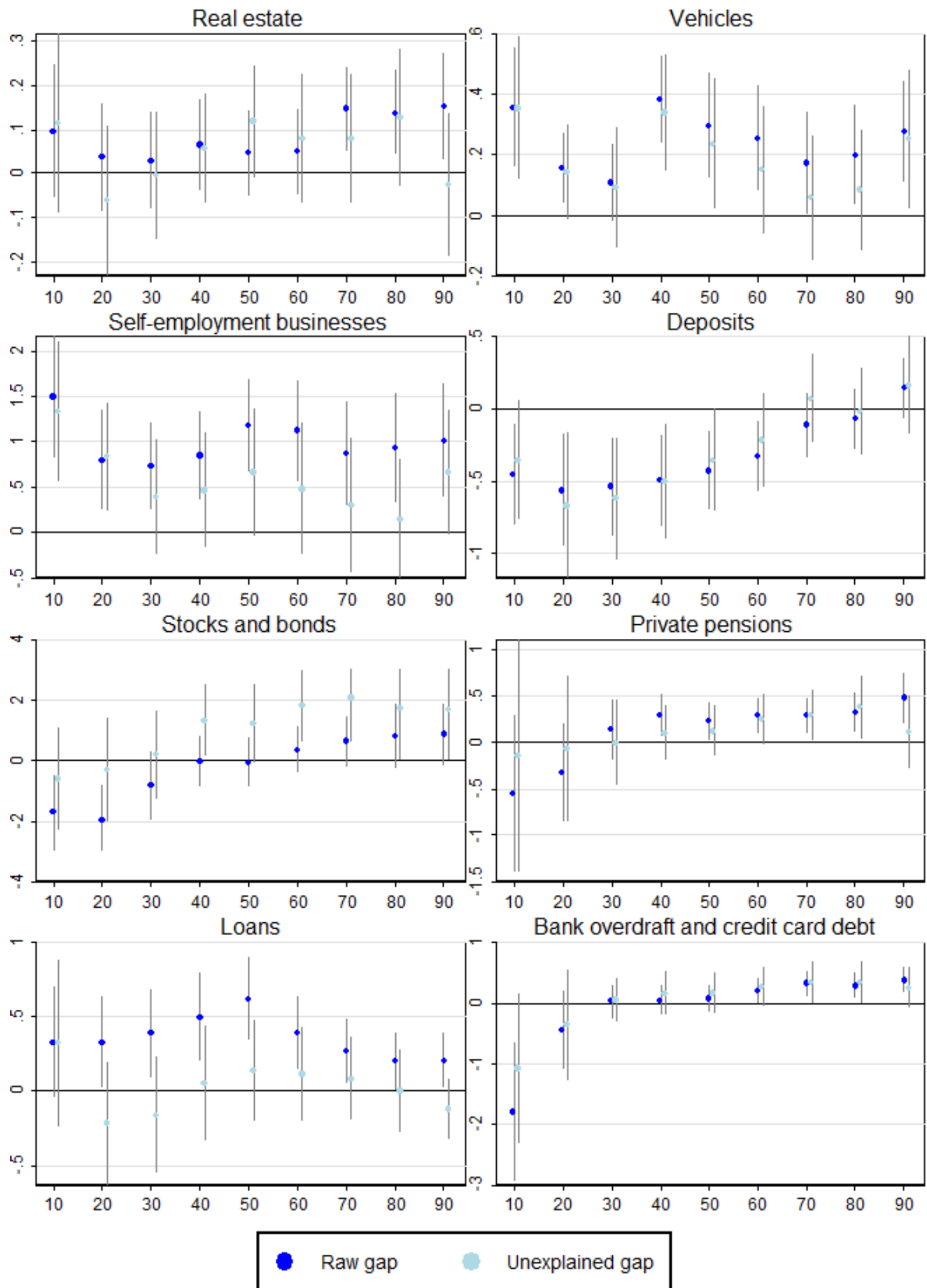

Source: Authors' calculations from the Estonian HFCS.

Notes: The vertical scale refers to the difference between the logarithmic values of a given wealth item for men and women. The wealth gaps are presented conditional on participation. Confidence bounds refer to statistical significance at $10 \%$ level. 


\section{Appendix 6: Results of the detailed decomposition of the gender wealth gaps over quantiles of net wealth, single-member households}

\begin{tabular}{|c|c|c|c|c|c|c|c|c|c|}
\hline & $\begin{array}{c}10^{\text {th }} \\
\text { quantile }\end{array}$ & $\begin{array}{c}20^{\text {th }} \\
\text { quantile }\end{array}$ & $\begin{array}{c}30^{\text {th }} \\
\text { quantile }\end{array}$ & $\begin{array}{c}40^{\text {th }} \\
\text { quantile }\end{array}$ & $\begin{array}{c}\mathbf{5 0}^{\text {th }} \\
\text { quantile }\end{array}$ & $\begin{array}{c}\mathbf{6 0}^{\text {th }} \\
\text { quantile }\end{array}$ & $\begin{array}{c}\mathbf{7 0}^{\text {th }} \\
\text { quantile }\end{array}$ & $\begin{array}{c}\mathbf{8 0}^{\text {th }} \\
\text { quantile }\end{array}$ & $\begin{array}{c}90^{\text {th }} \\
\text { quantile }\end{array}$ \\
\hline \multicolumn{10}{|l|}{ The explained gap } \\
\hline Total & $\begin{array}{l}-1.298 \\
(0.832)\end{array}$ & $\begin{array}{c}-2.041^{* *} \\
(1.020)\end{array}$ & $\begin{array}{l}-2.349 \\
(1.516)\end{array}$ & $\begin{array}{l}-0.606 \\
(0.624)\end{array}$ & $\begin{array}{c}-1.050^{* * *} \\
(0.440)\end{array}$ & $\begin{array}{c}-1.215^{* * *} \\
(0.418)\end{array}$ & $\begin{array}{c}-0.918^{* * *} \\
(0.408)\end{array}$ & $\begin{array}{c}-1.361^{* * *} \\
(0.417)\end{array}$ & $\begin{array}{l}-0.699 \\
(0.461)\end{array}$ \\
\hline Status self-employed, base employee & $\begin{array}{c}0.114 \\
(0.095)\end{array}$ & $\begin{array}{c}0.154 \\
(0.109)\end{array}$ & $\begin{array}{c}0.036 \\
(0.234)\end{array}$ & $\begin{array}{l}-0.058 \\
(0.089)\end{array}$ & $\begin{array}{c}0.027 \\
(0.066)\end{array}$ & $\begin{array}{c}0.045 \\
(0.058)\end{array}$ & $\begin{array}{c}0.070 \\
(0.065)\end{array}$ & $\begin{array}{c}0.023 \\
(0.040)\end{array}$ & $\begin{array}{c}0.069 \\
(0.059)\end{array}$ \\
\hline Status unemployed, base employee & $\begin{array}{c}0.255 \\
(0.305)\end{array}$ & $\begin{array}{c}0.089 \\
(0.364)\end{array}$ & $\begin{array}{l}-0.021 \\
(0.532)\end{array}$ & $\begin{array}{c}0.004 \\
(0.212)\end{array}$ & $\begin{array}{c}0.049 \\
(0.141)\end{array}$ & $\begin{array}{l}-0.068 \\
(0.116)\end{array}$ & $\begin{array}{l}-0.066 \\
(0.101)\end{array}$ & $\begin{array}{l}-0.127 \\
(0.086)\end{array}$ & $\begin{array}{c}0.051 \\
(0.064)\end{array}$ \\
\hline Status other inactive, base employee & $\begin{array}{c}0.101 \\
(0.212)\end{array}$ & $\begin{array}{c}-0.113 \\
(0.258)\end{array}$ & $\begin{array}{l}-0.591 \\
(0.443)\end{array}$ & $\begin{array}{l}-0.167 \\
(0.149)\end{array}$ & $\begin{array}{l}-0.011 \\
(0.088)\end{array}$ & $\begin{array}{c}0.033 \\
(0.082)\end{array}$ & $\begin{array}{c}0.045 \\
(0.077)\end{array}$ & $\begin{array}{c}0.040 \\
(0.075)\end{array}$ & $\begin{array}{c}0.091 \\
(0.073)\end{array}$ \\
\hline Status retiree, base employee & $\begin{array}{l}-0.623 \\
(0.509)\end{array}$ & $\begin{array}{c}0.784 \\
(1.047)\end{array}$ & $\begin{array}{c}1.104 \\
(1.341)\end{array}$ & $\begin{array}{c}0.768 \\
(0.630)\end{array}$ & $\begin{array}{c}0.251 \\
(0.420)\end{array}$ & $\begin{array}{c}0.315 \\
(0.379)\end{array}$ & $\begin{array}{c}0.178 \\
(0.337)\end{array}$ & $\begin{array}{c}0.566^{*} \\
(0.332)\end{array}$ & $\begin{array}{c}0.051 \\
(0.316)\end{array}$ \\
\hline Time in employment & $\begin{array}{c}0.422 \\
(1.477)\end{array}$ & $\begin{array}{c}1.364 \\
(2.131)\end{array}$ & $\begin{array}{c}1.391 \\
(3.359)\end{array}$ & $\begin{array}{l}-0.407 \\
(1.365)\end{array}$ & $\begin{array}{c}-0.532 \\
(0.898)\end{array}$ & $\begin{array}{l}-0.733 \\
(0.709)\end{array}$ & $\begin{array}{l}-0.100 \\
(0.579)\end{array}$ & $\begin{array}{c}0.349 \\
(0.562)\end{array}$ & $\begin{array}{c}0.314 \\
(0.470)\end{array}$ \\
\hline Time in employment squared / 100 & $\begin{array}{l}-0.802 \\
(1.429)\end{array}$ & $\begin{array}{l}-2.127 \\
(1.977)\end{array}$ & $\begin{array}{l}-3.960 \\
(3.039)\end{array}$ & $\begin{array}{l}-0.333 \\
(1.415)\end{array}$ & $\begin{array}{l}-0.129 \\
(0.929)\end{array}$ & $\begin{array}{c}0.115 \\
(0.798)\end{array}$ & $\begin{array}{l}-0.573 \\
(0.703)\end{array}$ & $\begin{array}{l}-0.802 \\
(0.709)\end{array}$ & $\begin{array}{c}-0.992^{*} \\
(0.602)\end{array}$ \\
\hline Income, thousand EUR & $\begin{array}{l}-0.006 \\
(0.192)\end{array}$ & $\begin{array}{c}0.088 \\
(0.216)\end{array}$ & $\begin{array}{c}0.312 \\
(0.422)\end{array}$ & $\begin{array}{c}0.147 \\
(0.187)\end{array}$ & $\begin{array}{c}0.140 \\
(0.166)\end{array}$ & $\begin{array}{c}0.116 \\
(0.141)\end{array}$ & $\begin{array}{c}0.130 \\
(0.154)\end{array}$ & $\begin{array}{c}0.108 \\
(0.133)\end{array}$ & $\begin{array}{c}0.116 \\
(0.140)\end{array}$ \\
\hline Income squared /100 & $\begin{array}{l}-0.106 \\
(0.181)\end{array}$ & $\begin{array}{l}-0.147 \\
(0.225)\end{array}$ & $\begin{array}{l}-0.282 \\
(0.395)\end{array}$ & $\begin{array}{l}-0.110 \\
(0.156)\end{array}$ & $\begin{array}{l}-0.099 \\
(0.134)\end{array}$ & $\begin{array}{l}-0.080 \\
(0.111)\end{array}$ & $\begin{array}{l}-0.088 \\
(0.120)\end{array}$ & $\begin{array}{l}-0.067 \\
(0.096)\end{array}$ & $\begin{array}{l}-0.070 \\
(0.099)\end{array}$ \\
\hline Secondary education, base primary & $\begin{array}{c}0.318 \\
(0.307)\end{array}$ & $\begin{array}{c}0.574 \\
(0.439)\end{array}$ & $\begin{array}{c}1.050 \\
(0.639)\end{array}$ & $\begin{array}{c}0.218 \\
(0.229)\end{array}$ & $\begin{array}{c}0.217 \\
(0.170)\end{array}$ & $\begin{array}{c}0.223 \\
(0.139)\end{array}$ & $\begin{array}{c}0.199^{*} \\
(0.115)\end{array}$ & $\begin{array}{c}0.173^{*} \\
(0.104)\end{array}$ & $\begin{array}{c}0.119 \\
(0.084)\end{array}$ \\
\hline Tertiary education, base primary & $\begin{array}{l}-0.491 \\
(0.421)\end{array}$ & $\begin{array}{l}-0.563 \\
(0.537)\end{array}$ & $\begin{array}{l}-1.107 \\
(0.788)\end{array}$ & $\begin{array}{l}-0.409 \\
(0.307)\end{array}$ & $\begin{array}{l}-0.236 \\
(0.245)\end{array}$ & $\begin{array}{l}-0.353 \\
(0.226)\end{array}$ & $\begin{array}{l}-0.179 \\
(0.178)\end{array}$ & $\begin{array}{l}-0.140 \\
(0.147)\end{array}$ & $\begin{array}{l}-0.101 \\
(0.108)\end{array}$ \\
\hline Training in education, base general programmes & $\begin{array}{l}-0.290 \\
(0.244)\end{array}$ & $\begin{array}{l}-0.400 \\
(0.310)\end{array}$ & $\begin{array}{l}-0.686 \\
(0.485)\end{array}$ & $\begin{array}{l}-0.330 \\
(0.206)\end{array}$ & $\begin{array}{c}-0.359^{* * *} \\
(0.165)\end{array}$ & $\begin{array}{l}-0.219 \\
(0.136)\end{array}$ & $\begin{array}{c}-0.305^{* * *} \\
(0.130)\end{array}$ & $\begin{array}{c}-0.392^{* * * *} \\
(0.129)\end{array}$ & $\begin{array}{c}-0.542^{* * * *} \\
(0.144)\end{array}$ \\
\hline Training in humanities, base general programmes & $\begin{array}{c}0.211 \\
(0.275)\end{array}$ & $\begin{array}{c}0.186 \\
(0.258)\end{array}$ & $\begin{array}{c}0.486 \\
(0.362)\end{array}$ & $\begin{array}{c}0.143 \\
(0.120)\end{array}$ & $\begin{array}{c}0.086 \\
(0.076)\end{array}$ & $\begin{array}{c}0.072 \\
(0.070)\end{array}$ & $\begin{array}{c}0.007 \\
(0.043)\end{array}$ & $\begin{array}{l}-0.001 \\
(0.040)\end{array}$ & $\begin{array}{l}-0.011 \\
(0.048)\end{array}$ \\
\hline Training in social sciences, base general programmes & $\begin{array}{c}0.109 \\
(0.255)\end{array}$ & $\begin{array}{c}-0.014 \\
(0.235)\end{array}$ & $\begin{array}{c}0.205 \\
(0.375)\end{array}$ & $\begin{array}{c}0.147 \\
(0.141)\end{array}$ & $\begin{array}{c}0.097 \\
(0.099)\end{array}$ & $\begin{array}{c}0.099 \\
(0.096)\end{array}$ & $\begin{array}{l}-0.018 \\
(0.075)\end{array}$ & $\begin{array}{l}-0.018 \\
(0.069)\end{array}$ & $\begin{array}{c}0.025 \\
(0.068)\end{array}$ \\
\hline Training in science, base general programmes & $\begin{array}{l}-0.014 \\
(0.059)\end{array}$ & $\begin{array}{l}-0.012 \\
(0.057)\end{array}$ & $\begin{array}{l}-0.002 \\
(0.055)\end{array}$ & $\begin{array}{l}-0.001 \\
(0.021)\end{array}$ & $\begin{array}{l}-0.002 \\
(0.019)\end{array}$ & $\begin{array}{l}-0.002 \\
(0.018)\end{array}$ & $\begin{array}{l}-0.009 \\
(0.033)\end{array}$ & $\begin{array}{l}-0.015 \\
(0.051)\end{array}$ & $\begin{array}{l}-0.011 \\
(0.048)\end{array}$ \\
\hline
\end{tabular}


Training in engineering, base general programmes

Training in agriculture, base general programmes

Training in health, base general programmes

Training in services, base general programs

Age

Age squared / 100

Immigrant, base born in Estonia

One child, base no children

Two children, base no children

Three children, base no children

Child under three years, base other

Marital status widow, base single/never married

Marital status divorced, base single/never married

Region north, base central Estonia

Region west, base central Estonia

Region south, base central Estonia

Region east, base central Estonia

Other town, base capital town

Village, base capital town

\begin{tabular}{|c|c|c|c|c|c|c|c|c|}
\hline 0.031 & 0.010 & 0.116 & 0.206 & -0.100 & -0.085 & -0.056 & $-0.174^{*}$ & -0.082 \\
\hline$(0.214)$ & (0.319) & $(0.442)$ & $(0.201)$ & $(0.141)$ & $(0.129)$ & (0.118) & $(0.102)$ & $(0.065)$ \\
\hline-0.003 & -0.080 & 0.068 & -0.034 & -0.048 & -0.046 & 0.031 & 0.049 & -0.005 \\
\hline$(0.084)$ & $(0.121)$ & $(0.238)$ & $(0.079)$ & $(0.056)$ & $(0.055)$ & $(0.046)$ & $(0.057)$ & $(0.053)$ \\
\hline 0.000 & 0.000 & 0.000 & 0.000 & 0.000 & 0.000 & 0.000 & 0.000 & 0.000 \\
\hline (.) & (.) & (.) & (.) & (.) & (.) & (.) & (.) & (.) \\
\hline 0.000 & 0.106 & 0.066 & 0.088 & 0.035 & 0.010 & 0.014 & 0.015 & 0.015 \\
\hline$(0.069)$ & $(0.123)$ & $(0.190)$ & $(0.095)$ & $(0.062)$ & $(0.041)$ & $(0.040)$ & $(0.044)$ & $(0.040)$ \\
\hline 1.381 & 4.918 & 4.954 & 1.195 & -0.497 & 0.263 & -1.290 & -0.749 & -0.649 \\
\hline (3.394) & (4.323) & $(6.430)$ & (2.391) & (1.702) & $(1.289)$ & (1.210) & (1.183) & $(1.052)$ \\
\hline-1.829 & -5.942 & -6.391 & -2.121 & 0.001 & -0.317 & 1.506 & 0.254 & 0.861 \\
\hline (3.407) & (4.398) & (6.449) & $(2.538)$ & (1.878) & (1.538) & $(1.455)$ & (1.473) & (1.336) \\
\hline 0.225 & 0.061 & 0.515 & 0.263 & 0.106 & 0.044 & -0.039 & -0.050 & 0.040 \\
\hline$(0.240)$ & $(0.252)$ & $(0.420)$ & $(0.169)$ & $(0.106)$ & $(0.074)$ & $(0.067)$ & $(0.066)$ & $(0.056)$ \\
\hline-0.227 & -0.310 & $-0.847^{*}$ & $-0.374^{*}$ & $-0.391^{* * *}$ & $-0.349^{* * *}$ & -0.282 & $-0.522^{* * *}$ & -0.118 \\
\hline$(0.274)$ & $(0.357)$ & $(0.468)$ & $(0.195)$ & $(0.142)$ & $(0.131)$ & $(0.176)$ & $(0.214)$ & $(0.285)$ \\
\hline 0.006 & 0.028 & 0.025 & 0.005 & 0.004 & 0.010 & 0.004 & -0.006 & 0.003 \\
\hline$(0.069)$ & $(0.120)$ & $(0.143)$ & $(0.055)$ & $(0.046)$ & $(0.047)$ & $(0.045)$ & $(0.040)$ & $(0.013)$ \\
\hline 0.000 & 0.000 & 0.000 & 0.000 & 0.000 & 0.000 & 0.000 & 0.000 & 0.000 \\
\hline (.) & (.) & (.) & (.) & (.) & (.) & (.) & (.) & (.) \\
\hline-0.259 & -0.334 & -0.554 & 0.144 & 0.113 & 0.130 & 0.179 & $0.188^{*}$ & $0.142^{*}$ \\
\hline$(0.238)$ & $(0.284)$ & $(0.398)$ & $(0.151)$ & $(0.110)$ & $(0.103)$ & $(0.114)$ & (0.109) & $(0.079)$ \\
\hline 0.001 & -0.177 & 1.978 & 0.567 & 0.412 & -0.202 & -0.097 & -0.040 & 0.001 \\
\hline$(0.528)$ & $(0.956)$ & $(1.482)$ & $(0.608)$ & $(0.454)$ & $(0.364)$ & $(0.331)$ & $(0.331)$ & $(0.367)$ \\
\hline 0.004 & 0.005 & -0.005 & -0.004 & -0.003 & -0.001 & -0.001 & -0.001 & -0.002 \\
\hline$(0.073)$ & $(0.108)$ & $(0.157)$ & $(0.072)$ & $(0.055)$ & $(0.036)$ & $(0.027)$ & $(0.028)$ & $(0.033)$ \\
\hline-0.098 & -0.257 & -0.351 & -0.082 & -0.072 & -0.023 & -0.090 & -0.107 & 0.005 \\
\hline$(0.149)$ & $(0.301)$ & $(0.413)$ & $(0.153)$ & $(0.117)$ & $(0.096)$ & $(0.098)$ & $(0.106)$ & $(0.063)$ \\
\hline-0.010 & 0.091 & 0.018 & -0.029 & -0.004 & 0.017 & 0.053 & 0.048 & 0.030 \\
\hline (0.094) & $(0.158)$ & $(0.185)$ & $(0.078)$ & $(0.047)$ & $(0.044)$ & $(0.067)$ & $(0.063)$ & $(0.048)$ \\
\hline-0.022 & -0.072 & -0.025 & 0.036 & -0.058 & -0.052 & -0.049 & -0.056 & 0.021 \\
\hline$(0.140)$ & $(0.228)$ & $(0.306)$ & $(0.120)$ & $(0.098)$ & $(0.085)$ & $(0.067)$ & $(0.066)$ & $(0.042)$ \\
\hline 0.079 & -0.005 & 0.097 & -0.080 & 0.044 & -0.081 & -0.024 & 0.025 & -0.070 \\
\hline$(0.174)$ & $(0.299)$ & $(0.452)$ & $(0.169)$ & $(0.131)$ & $(0.115)$ & $(0.066)$ & $(0.062)$ & $(0.058)$ \\
\hline-0.012 & -0.019 & -0.020 & -0.004 & 0.002 & 0.004 & 0.005 & -0.000 & -0.001 \\
\hline$(0.208)$ & $(0.313)$ & $(0.334)$ & $(0.104)$ & $(0.066)$ & $(0.085)$ & $(0.086)$ & $(0.044)$ & $(0.045)$ \\
\hline 0.234 & 0.074 & 0.073 & 0.007 & -0.090 & -0.099 & -0.074 & 0.070 & 0.001 \\
\hline$(0.203)$ & $(0.215)$ & $(0.271)$ & $(0.137)$ & $(0.118)$ & $(0.114)$ & $(0.098)$ & $(0.088)$ & $(0.069)$ \\
\hline
\end{tabular}




\begin{tabular}{|c|c|c|c|c|c|c|c|c|c|}
\hline \multicolumn{10}{|l|}{ The unexplained gap } \\
\hline Total & $\begin{array}{c}0.700 \\
(1.102)\end{array}$ & $\begin{array}{c}-2.968^{* *} \\
(1.358)\end{array}$ & $\begin{array}{l}-1.351 \\
(1.528)\end{array}$ & $\begin{array}{l}-0.845 \\
(0.636)\end{array}$ & $\begin{array}{c}0.385 \\
(0.450)\end{array}$ & $\begin{array}{c}0.632 \\
(0.434)\end{array}$ & $\begin{array}{c}0.513 \\
(0.419)\end{array}$ & $\begin{array}{l}1.155^{* * *} \\
(0.439)\end{array}$ & $\begin{array}{c}0.819 \\
(0.500)\end{array}$ \\
\hline Status self-employed, base employee & $\begin{array}{c}0.064 \\
(0.145)\end{array}$ & $\begin{array}{c}0.051 \\
(0.127)\end{array}$ & $\begin{array}{l}-0.021 \\
(0.117)\end{array}$ & $\begin{array}{l}-0.048 \\
(0.047)\end{array}$ & $\begin{array}{l}-0.009 \\
(0.034)\end{array}$ & $\begin{array}{l}-0.004 \\
(0.028)\end{array}$ & $\begin{array}{c}0.015 \\
(0.030)\end{array}$ & $\begin{array}{l}-0.008 \\
(0.023)\end{array}$ & $\begin{array}{c}0.021 \\
(0.027)\end{array}$ \\
\hline Status unemployed, base employee & $\begin{array}{l}-0.035 \\
(0.147)\end{array}$ & $\begin{array}{c}0.152 \\
(0.176)\end{array}$ & $\begin{array}{c}-0.022 \\
(0.141)\end{array}$ & $\begin{array}{l}-0.003 \\
(0.057)\end{array}$ & $\begin{array}{l}-0.004 \\
(0.038)\end{array}$ & $\begin{array}{c}-0.045 \\
(0.034)\end{array}$ & $\begin{array}{c}-0.038 \\
(0.031)\end{array}$ & $\begin{array}{l}-0.048 \\
(0.030)\end{array}$ & $\begin{array}{c}0.008 \\
(0.024)\end{array}$ \\
\hline Status other inactive, base employee & $\begin{array}{l}-0.018 \\
(0.412)\end{array}$ & $\begin{array}{c}0.047 \\
(0.466)\end{array}$ & $\begin{array}{l}-0.701 \\
(0.460)\end{array}$ & $\begin{array}{r}-0.249 \\
(0.174)\end{array}$ & $\begin{array}{c}-0.009 \\
(0.116)\end{array}$ & $\begin{array}{c}-0.001 \\
(0.105)\end{array}$ & $\begin{array}{c}0.013 \\
(0.098)\end{array}$ & $\begin{array}{c}0.009 \\
(0.094)\end{array}$ & $\begin{array}{c}0.094 \\
(0.083)\end{array}$ \\
\hline Status retiree, base employee & $\begin{array}{c}2.344^{*} \\
(1.414)\end{array}$ & $\begin{array}{c}1.620 \\
(2.455)\end{array}$ & $\begin{array}{l}-1.167 \\
(2.464)\end{array}$ & $\begin{array}{l}-0.868 \\
(1.179)\end{array}$ & $\begin{array}{l}-0.007 \\
(0.809)\end{array}$ & $\begin{array}{l}-0.269 \\
(0.718)\end{array}$ & $\begin{array}{l}-0.027 \\
(0.643)\end{array}$ & $\begin{array}{l}-0.746 \\
(0.619)\end{array}$ & $\begin{array}{c}0.097 \\
(0.605)\end{array}$ \\
\hline Time in employment & $\begin{array}{c}2.963 \\
(6.497)\end{array}$ & $\begin{array}{c}1.274 \\
(10.150)\end{array}$ & $\begin{array}{c}-5.534 \\
(13.129)\end{array}$ & $\begin{array}{c}0.955 \\
(5.466)\end{array}$ & $\begin{array}{c}0.902 \\
(3.627)\end{array}$ & $\begin{array}{c}0.999 \\
(2.806)\end{array}$ & $\begin{array}{c}-0.688 \\
(2.361)\end{array}$ & $\begin{array}{l}-2.444 \\
(2.252)\end{array}$ & $\begin{array}{l}-1.179 \\
(1.895)\end{array}$ \\
\hline Time in employment squared / 100 & $\begin{array}{l}-0.043 \\
(4.414)\end{array}$ & $\begin{array}{c}3.882 \\
(7.054)\end{array}$ & $\begin{array}{l}11.767 \\
(8.244)\end{array}$ & $\begin{array}{c}1.551 \\
(3.993)\end{array}$ & $\begin{array}{c}1.125 \\
(2.647)\end{array}$ & $\begin{array}{c}0.901 \\
(2.255)\end{array}$ & $\begin{array}{c}2.370 \\
(1.981)\end{array}$ & $\begin{array}{c}2.840 \\
(1.968)\end{array}$ & $\begin{array}{c}2.643 \\
(1.633)\end{array}$ \\
\hline Income, thousand EUR & $\begin{array}{c}1.556 \\
(1.407)\end{array}$ & $\begin{array}{l}-0.527 \\
(1.345)\end{array}$ & $\begin{array}{c}1.792 \\
(1.242)\end{array}$ & $\begin{array}{c}0.663 \\
(0.516)\end{array}$ & $\begin{array}{l}0.804^{* *} \\
(0.374)\end{array}$ & $\begin{array}{l}0.715^{* *} \\
(0.347)\end{array}$ & $\begin{array}{l}0.752^{\text {** }} \\
(0.345)\end{array}$ & $\begin{array}{c}0.501 \\
(0.338)\end{array}$ & $\begin{array}{c}0.580^{*} \\
(0.331)\end{array}$ \\
\hline Income squared /100 & $\begin{array}{c}-0.513^{*} \\
(0.293)\end{array}$ & $\begin{array}{l}-0.165 \\
(0.228)\end{array}$ & $\begin{array}{c}-0.433^{*} \\
(0.235)\end{array}$ & $\begin{array}{l}-0.152 \\
(0.096)\end{array}$ & $\begin{array}{c}-0.157^{* * *} \\
(0.080)\end{array}$ & $\begin{array}{c}-0.132^{*} \\
(0.070)\end{array}$ & $\begin{array}{c}-0.141^{*} \\
(0.072)\end{array}$ & $\begin{array}{l}-0.101 \\
(0.063)\end{array}$ & $\begin{array}{c}-0.119^{*} \\
(0.066)\end{array}$ \\
\hline Secondary education, base primary & $\begin{array}{c}0.486 \\
(1.175)\end{array}$ & $\begin{array}{l}1.248 \\
(1.560)\end{array}$ & $\begin{array}{l}2.793^{*} \\
(1.567)\end{array}$ & $\begin{array}{c}0.134 \\
(0.646)\end{array}$ & $\begin{array}{c}0.151 \\
(0.464)\end{array}$ & $\begin{array}{c}0.299 \\
(0.365)\end{array}$ & $\begin{array}{c}0.444 \\
(0.303)\end{array}$ & $\begin{array}{c}0.368 \\
(0.283)\end{array}$ & $\begin{array}{c}0.352 \\
(0.241)\end{array}$ \\
\hline Tertiary education, base primary & $\begin{array}{c}0.311 \\
(1.336)\end{array}$ & $\begin{array}{c}0.059 \\
(1.815)\end{array}$ & $\begin{array}{c}2.469 \\
(1.894)\end{array}$ & $\begin{array}{c}0.430 \\
(0.781)\end{array}$ & $\begin{array}{c}0.026 \\
(0.640)\end{array}$ & $\begin{array}{c}0.437 \\
(0.549)\end{array}$ & $\begin{array}{c}0.285 \\
(0.468)\end{array}$ & $\begin{array}{c}0.267 \\
(0.399)\end{array}$ & $\begin{array}{c}0.105 \\
(0.304)\end{array}$ \\
\hline Training in education, base general programmes & $\begin{array}{c}0.491 \\
(0.375)\end{array}$ & $\begin{array}{c}0.396 \\
(0.433)\end{array}$ & $\begin{array}{c}0.714 \\
(0.526)\end{array}$ & $\begin{array}{c}0.340 \\
(0.229)\end{array}$ & $\begin{array}{l}0.431^{* * *} \\
(0.184)\end{array}$ & $\begin{array}{c}0.286^{*} \\
(0.153)\end{array}$ & $\begin{array}{l}0.338^{* * *} \\
(0.142)\end{array}$ & $\begin{array}{c}0.421^{\text {**** }} \\
(0.137)\end{array}$ & $\begin{array}{c}0.641^{\text {**** }} \\
(0.152)\end{array}$ \\
\hline Training in humanities, base general programmes & $\begin{array}{l}-0.447 \\
(0.438)\end{array}$ & $\begin{array}{l}-0.442 \\
(0.436)\end{array}$ & $\begin{array}{c}-1.024^{* * * *} \\
(0.348)\end{array}$ & $\begin{array}{c}-0.291^{\text {*** }} \\
(0.142)\end{array}$ & $\begin{array}{c}-0.170^{*} \\
(0.098)\end{array}$ & $\begin{array}{c}-0.140 \\
(0.095)\end{array}$ & $\begin{array}{c}-0.014 \\
(0.076)\end{array}$ & $\begin{array}{l}-0.001 \\
(0.072)\end{array}$ & $\begin{array}{c}0.020 \\
(0.084)\end{array}$ \\
\hline Training in social sciences, base general programmes & $\begin{array}{r}-0.760 \\
(0.763)\end{array}$ & $\begin{array}{r}-0.082 \\
(0.798)\end{array}$ & $\begin{array}{r}-0.563 \\
(0.930)\end{array}$ & $\begin{array}{l}-0.361 \\
(0.335)\end{array}$ & $\begin{array}{r}-0.173 \\
(0.241)\end{array}$ & $\begin{array}{r}-0.200 \\
(0.227)\end{array}$ & $\begin{array}{c}0.072 \\
(0.200)\end{array}$ & $\begin{array}{c}0.054 \\
(0.183)\end{array}$ & $\begin{array}{l}-0.021 \\
(0.177)\end{array}$ \\
\hline Training in science, base general programmes & $\begin{array}{c}0.053 \\
(0.180)\end{array}$ & $\begin{array}{c}0.165 \\
(0.177)\end{array}$ & $\begin{array}{c}0.082 \\
(0.100)\end{array}$ & $\begin{array}{c}0.054 \\
(0.044)\end{array}$ & $\begin{array}{c}0.037 \\
(0.035)\end{array}$ & $\begin{array}{c}0.028 \\
(0.030)\end{array}$ & $\begin{array}{c}0.049 \\
(0.031)\end{array}$ & $\begin{array}{l}0.075^{* *} \\
(0.037)\end{array}$ & $\begin{array}{c}0.066 \\
(0.055)\end{array}$ \\
\hline Training in engineering, base general programmes & $\begin{array}{l}-0.124 \\
(0.395)\end{array}$ & $\begin{array}{l}-0.237 \\
(0.544)\end{array}$ & $\begin{array}{l}-0.041 \\
(0.485)\end{array}$ & $\begin{array}{c}0.119 \\
(0.223)\end{array}$ & $\begin{array}{l}-0.167 \\
(0.164)\end{array}$ & $\begin{array}{c}-0.144 \\
(0.148)\end{array}$ & $\begin{array}{c}-0.113 \\
(0.137)\end{array}$ & $\begin{array}{c}-0.249^{* *} \\
(0.114)\end{array}$ & $\begin{array}{l}-0.074 \\
(0.081)\end{array}$ \\
\hline Training in agriculture, base general programmes & $\begin{array}{c}0.028 \\
(0.231)\end{array}$ & $\begin{array}{l}-0.058 \\
(0.275)\end{array}$ & $\begin{array}{l}-0.171 \\
(0.379)\end{array}$ & $\begin{array}{c}0.064 \\
(0.132)\end{array}$ & $\begin{array}{c}0.110 \\
(0.091)\end{array}$ & $\begin{array}{c}0.103 \\
(0.086)\end{array}$ & $\begin{array}{l}-0.029 \\
(0.072)\end{array}$ & $\begin{array}{l}-0.070 \\
(0.085)\end{array}$ & $\begin{array}{c}0.036 \\
(0.085)\end{array}$ \\
\hline Training in health, base general programmes & $\begin{array}{l}-0.023 \\
(0.205)\end{array}$ & $\begin{array}{c}0.067 \\
(0.277)\end{array}$ & $\begin{array}{c}0.007 \\
(0.083)\end{array}$ & $\begin{array}{c}0.011 \\
(0.062)\end{array}$ & $\begin{array}{l}-0.009 \\
(0.046)\end{array}$ & $\begin{array}{l}-0.041 \\
(0.037)\end{array}$ & $\begin{array}{c}-0.071^{*} \\
(0.038)\end{array}$ & $\begin{array}{c}-0.070^{*} \\
(0.041)\end{array}$ & $\begin{array}{c}0.013 \\
(0.035)\end{array}$ \\
\hline Training in services, base general programmes & $\begin{array}{l}-0.124 \\
(0.230)\end{array}$ & $\begin{array}{c}0.201 \\
(0.275)\end{array}$ & $\begin{array}{c}0.094 \\
(0.244)\end{array}$ & $\begin{array}{c}0.159 \\
(0.108)\end{array}$ & $\begin{array}{c}0.060 \\
(0.079)\end{array}$ & $\begin{array}{c}0.004 \\
(0.057)\end{array}$ & $\begin{array}{c}0.000 \\
(0.055)\end{array}$ & $\begin{array}{l}-0.004 \\
(0.058)\end{array}$ & $\begin{array}{c}0.025 \\
(0.052)\end{array}$ \\
\hline Age & $\begin{array}{c}-65.352^{* * *} \\
(25.189)\end{array}$ & $\begin{array}{c}-92.913^{* * *} \\
(30.867)\end{array}$ & $\begin{array}{l}-49.276 \\
(34.535)\end{array}$ & $\begin{array}{l}-21.343 \\
(13.394)\end{array}$ & $\begin{array}{l}-4.851 \\
(9.665)\end{array}$ & $\begin{array}{l}-6.036 \\
(7.276)\end{array}$ & $\begin{array}{c}4.336 \\
(6.718)\end{array}$ & $\begin{array}{c}2.973 \\
(6.524)\end{array}$ & $\begin{array}{c}0.899 \\
(5.810)\end{array}$ \\
\hline
\end{tabular}




\begin{tabular}{|c|c|c|c|c|c|c|c|c|c|}
\hline Age squared / 100 & $\begin{array}{c}26.324^{*} \\
(13.921)\end{array}$ & $\begin{array}{l}41.265^{* *} \\
(18.182)\end{array}$ & $\begin{array}{c}28.632 \\
(20.383)\end{array}$ & $\begin{array}{l}12.453 \\
(8.321)\end{array}$ & $\begin{array}{c}2.273 \\
(6.233)\end{array}$ & $\begin{array}{c}1.730 \\
(5.042)\end{array}$ & $\begin{array}{l}-5.018 \\
(4.710)\end{array}$ & $\begin{array}{l}-1.547 \\
(4.765)\end{array}$ & $\begin{array}{l}-2.024 \\
(4.294)\end{array}$ \\
\hline \multirow[t]{2}{*}{ Immigrant, base born in Estonia } & -0.118 & 0.896 & -1.168 & $-0.637^{*}$ & -0.292 & -0.055 & 0.193 & $0.270^{*}$ & 0.014 \\
\hline & $(0.631)$ & $(0.781)$ & $(0.895)$ & $(0.351)$ & $(0.245)$ & $(0.178)$ & $(0.163)$ & $(0.160)$ & $(0.133)$ \\
\hline \multirow[t]{2}{*}{ One child, base no children } & 0.228 & 0.212 & $0.955^{\circ}$ & 0.361 & $0.410^{* * * * *}$ & $0.366^{* *}$ & 0.263 & $0.555^{* *}$ & 0.080 \\
\hline & $(0.453)$ & $(0.508)$ & $(0.529)$ & $(0.223)$ & $(0.157)$ & $(0.144)$ & $(0.198)$ & $(0.234)$ & $(0.327)$ \\
\hline \multirow[t]{2}{*}{ Two children, base no children } & 0.174 & 0.135 & -0.091 & -0.032 & -0.040 & -0.069 & -0.030 & 0.018 & -0.024 \\
\hline & $(0.243)$ & $(0.272)$ & $(0.286)$ & $(0.118)$ & $(0.099)$ & $(0.091)$ & $(0.095)$ & $(0.082)$ & $(0.032)$ \\
\hline \multirow[t]{2}{*}{ Three children, base no children } & -0.076 & -0.098 & -0.038 & -0.030 & -0.019 & -0.015 & -0.015 & -0.006 & -0.003 \\
\hline & $(0.057)$ & $(0.074)$ & $(0.027)$ & $(0.021)$ & $(0.014)$ & $(0.013)$ & $(0.012)$ & $(0.005)$ & $(0.005)$ \\
\hline \multirow[t]{2}{*}{ Child under three years, base other } & 0.270 & 0.329 & 0.635 & -0.179 & -0.113 & -0.138 & -0.189 & $-0.211^{*}$ & $-0.164^{* *}$ \\
\hline & $(0.330)$ & $(0.346)$ & $(0.425)$ & $(0.172)$ & $(0.122)$ & $(0.112)$ & $(0.118)$ & $(0.111)$ & $(0.082)$ \\
\hline \multirow[t]{2}{*}{ Marital status widow, base single/never married } & 1.004 & 0.608 & -2.987 & -0.913 & -0.610 & 0.510 & 0.131 & 0.062 & -0.041 \\
\hline & $(1.154)$ & $(1.830)$ & $(2.291)$ & $(0.964)$ & $(0.721)$ & $(0.580)$ & $(0.531)$ & $(0.529)$ & $(0.581)$ \\
\hline \multirow[t]{2}{*}{ Marital status divorced, base single/never married } & 0.769 & 0.440 & -0.190 & -0.230 & -0.161 & 0.035 & -0.021 & -0.073 & -0.197 \\
\hline & $(0.593)$ & $(0.809)$ & $(0.936)$ & $(0.377)$ & $(0.268)$ & $(0.216)$ & $(0.177)$ & $(0.158)$ & $(0.132)$ \\
\hline \multirow[t]{2}{*}{ Region north, base central Estonia } & -0.378 & -1.659 & 1.890 & -0.073 & -0.209 & -0.705 & -0.190 & 0.085 & -0.367 \\
\hline & $(1.275)$ & $(1.973)$ & $(1.923)$ & $(0.864)$ & $(0.649)$ & $(0.575)$ & $(0.453)$ & $(0.443)$ & $(0.399)$ \\
\hline \multirow[t]{2}{*}{ Region west, base central Estonia } & -0.042 & -0.165 & 0.031 & -0.141 & -0.043 & -0.003 & $0.159^{*}$ & $0.155^{*}$ & 0.096 \\
\hline & $(0.294)$ & $(0.419)$ & $(0.466)$ & $(0.189)$ & $(0.127)$ & $(0.103)$ & $(0.087)$ & $(0.087)$ & $(0.089)$ \\
\hline \multirow[t]{2}{*}{ Region south, base central Estonia } & 0.569 & -0.227 & 0.018 & -0.434 & 0.132 & 0.006 & -0.014 & 0.117 & -0.213 \\
\hline & $(0.880)$ & $(1.312)$ & $(1.404)$ & $(0.559)$ & $(0.423)$ & $(0.356)$ & $(0.265)$ & $(0.244)$ & $(0.184)$ \\
\hline \multirow[t]{2}{*}{ Region east, base central Estonia } & -0.153 & $-0.919^{* *}$ & -0.055 & -0.164 & 0.042 & -0.079 & -0.023 & 0.014 & $-0.100^{*}$ \\
\hline & $(0.248)$ & $(0.437)$ & $(0.448)$ & $(0.178)$ & $(0.138)$ & $(0.114)$ & $(0.068)$ & $(0.064)$ & $(0.056)$ \\
\hline \multirow{2}{*}{ Other town, base capital town } & -0.154 & 0.571 & 2.063 & 0.211 & -0.617 & -0.772 & $-0.826^{*}$ & -0.219 & 0.226 \\
\hline & $(1.177)$ & $(1.517)$ & $(1.480)$ & $(0.759)$ & $(0.570)$ & $(0.520)$ & $(0.459)$ & $(0.423)$ & $(0.390)$ \\
\hline \multirow[t]{2}{*}{ Village, base capital town } & 0.074 & -0.328 & 0.148 & -0.146 & -0.464 & -0.418 & -0.291 & 0.181 & 0.036 \\
\hline & $(0.687)$ & $(0.994)$ & $(0.924)$ & $(0.482)$ & $(0.374)$ & $(0.345)$ & $(0.315)$ & $(0.284)$ & $(0.258)$ \\
\hline \multirow{2}{*}{ Constant } & $31.350^{* * * *}$ & $41.234^{* * * *}$ & 8.046 & $7.946^{*}$ & 2.007 & 3.477 & -1.170 & -2.016 & -0.709 \\
\hline & $(11.602)$ & $(12.673)$ & $(12.101)$ & $(4.612)$ & $(3.226)$ & $(3.001)$ & $(2.473)$ & $(2.342)$ & $(1.961)$ \\
\hline$N$ & 587 & 587 & 587 & 587 & 587 & 587 & 587 & 587 & 587 \\
\hline
\end{tabular}

Source: Authors' calculations from the Estonian HFCS.

Notes: Standard errors in parentheses. ${ }^{*},{ }^{* *},{ }^{* * *}$ refer to statistical significance at $10 \%, 5 \%$ and $1 \%$ level. 
Appendix 7: Results of the detailed decomposition of the gender wealth gaps over quantiles of net wealth, household with married partners

\begin{tabular}{|c|c|c|c|c|c|c|c|c|c|}
\hline & $\begin{array}{c}10^{\text {th }} \\
\text { quantile }\end{array}$ & $\begin{array}{c}\mathbf{2 0}^{\text {th }} \\
\text { quantile }\end{array}$ & $\begin{array}{c}\text { 30 }^{\text {th }} \\
\text { quantile }\end{array}$ & $\begin{array}{c}\mathbf{4 0}^{\text {th }} \\
\text { quantile }\end{array}$ & $\begin{array}{c}\mathbf{5 0}^{\text {th }} \\
\text { quantile }\end{array}$ & $\begin{array}{c}6^{\text {th }} \\
\text { quantile }\end{array}$ & $\begin{array}{c}\mathbf{7 0}^{\text {th }} \\
\text { quantile }\end{array}$ & $\begin{array}{c}\mathbf{8 0}^{\text {th }} \\
\text { quantile }\end{array}$ & $\begin{array}{c}\mathbf{9 0}^{\text {th }} \\
\text { quantile }\end{array}$ \\
\hline \multicolumn{10}{|l|}{ The explained gap } \\
\hline Total & $\begin{array}{c}6.482^{*} \\
(3.381)\end{array}$ & $\begin{array}{c}0.299^{*} \\
(0.171)\end{array}$ & $\begin{array}{c}0.149 \\
(0.099)\end{array}$ & $\begin{array}{c}0.117 \\
(0.083)\end{array}$ & $\begin{array}{c}0.136^{*} \\
(0.080)\end{array}$ & $\begin{array}{c}0.130^{*} \\
(0.077)\end{array}$ & $\begin{array}{c}0.139^{*} \\
(0.073)\end{array}$ & $\begin{array}{c}0.190^{* * *} \\
(0.073)\end{array}$ & $\begin{array}{c}0.209^{* * *} \\
(0.079)\end{array}$ \\
\hline Status self-employed, base employee & $\begin{array}{c}0.813^{*} \\
(0.429)\end{array}$ & $\begin{array}{c}0.062^{* * * *} \\
(0.023)\end{array}$ & $\begin{array}{l}0.042^{* * * *} \\
(0.015)\end{array}$ & $\begin{array}{c}0.046^{* * *} \\
(0.014)\end{array}$ & $\begin{array}{c}0.052^{* * * *} \\
(0.016)\end{array}$ & $\begin{array}{c}0.065^{* * * *} \\
(0.018)\end{array}$ & $\begin{array}{c}0.076^{* * *} \\
(0.021)\end{array}$ & $\begin{array}{c}0.072^{* * * *} \\
(0.021)\end{array}$ & $\begin{array}{l}0.052^{* *} \\
(0.020)\end{array}$ \\
\hline Status unemployed, base employee & $\begin{array}{l}-0.049 \\
(0.223)\end{array}$ & $\begin{array}{l}-0.002 \\
(0.009)\end{array}$ & $\begin{array}{l}-0.002 \\
(0.007)\end{array}$ & $\begin{array}{l}-0.002 \\
(0.007)\end{array}$ & $\begin{array}{l}-0.002 \\
(0.005)\end{array}$ & $\begin{array}{l}-0.000 \\
(0.003)\end{array}$ & $\begin{array}{l}-0.000 \\
(0.002)\end{array}$ & $\begin{array}{l}-0.000 \\
(0.002)\end{array}$ & $\begin{array}{c}0.000 \\
(0.001)\end{array}$ \\
\hline Status other inactive, base employee & $\begin{array}{c}0.963 \\
(1.436)\end{array}$ & $\begin{array}{c}0.018 \\
(0.071)\end{array}$ & $\begin{array}{c}0.066 \\
(0.045)\end{array}$ & $\begin{array}{c}0.038 \\
(0.035)\end{array}$ & $\begin{array}{c}0.014 \\
(0.030)\end{array}$ & $\begin{array}{l}-0.003 \\
(0.029)\end{array}$ & $\begin{array}{l}-0.005 \\
(0.027)\end{array}$ & $\begin{array}{l}-0.031 \\
(0.028)\end{array}$ & $\begin{array}{l}-0.054 \\
(0.037)\end{array}$ \\
\hline Status retiree, base employee & $\begin{array}{l}-0.024 \\
(0.190)\end{array}$ & $\begin{array}{l}-0.003 \\
(0.011)\end{array}$ & $\begin{array}{l}-0.003 \\
(0.009)\end{array}$ & $\begin{array}{l}-0.003 \\
(0.008)\end{array}$ & $\begin{array}{l}-0.003 \\
(0.009)\end{array}$ & $\begin{array}{l}-0.003 \\
(0.008)\end{array}$ & $\begin{array}{l}-0.003 \\
(0.008)\end{array}$ & $\begin{array}{l}-0.003 \\
(0.008)\end{array}$ & $\begin{array}{c}0.003 \\
(0.010)\end{array}$ \\
\hline Time in employment & $\begin{array}{l}-0.560 \\
(1.885)\end{array}$ & $\begin{array}{l}-0.092 \\
(0.124)\end{array}$ & $\begin{array}{l}-0.067 \\
(0.081)\end{array}$ & $\begin{array}{l}-0.087 \\
(0.071)\end{array}$ & $\begin{array}{l}-0.071 \\
(0.066)\end{array}$ & $\begin{array}{c}-0.145^{* *} \\
(0.071)\end{array}$ & $\begin{array}{l}-0.065 \\
(0.066)\end{array}$ & $\begin{array}{l}-0.019 \\
(0.061)\end{array}$ & $\begin{array}{c}0.017 \\
(0.063)\end{array}$ \\
\hline Time in employment squared / 100 & $\begin{array}{c}0.548 \\
(1.863)\end{array}$ & $\begin{array}{c}0.152 \\
(0.121)\end{array}$ & $\begin{array}{c}0.067 \\
(0.077)\end{array}$ & $\begin{array}{c}0.082 \\
(0.068)\end{array}$ & $\begin{array}{c}0.074 \\
(0.063)\end{array}$ & $\begin{array}{l}0.172^{* * *} \\
(0.072)\end{array}$ & $\begin{array}{c}0.095 \\
(0.066)\end{array}$ & $\begin{array}{c}0.070 \\
(0.066)\end{array}$ & $\begin{array}{c}0.015 \\
(0.065)\end{array}$ \\
\hline Income, thousand EUR & $\begin{array}{c}0.890 \\
(2.493)\end{array}$ & $\begin{array}{c}0.050 \\
(0.132)\end{array}$ & $\begin{array}{c}0.027 \\
(0.073)\end{array}$ & $\begin{array}{c}0.036 \\
(0.094)\end{array}$ & $\begin{array}{c}0.058 \\
(0.147)\end{array}$ & $\begin{array}{c}0.062 \\
(0.155)\end{array}$ & $\begin{array}{c}0.068 \\
(0.170)\end{array}$ & $\begin{array}{c}0.073 \\
(0.183)\end{array}$ & $\begin{array}{c}0.102 \\
(0.255)\end{array}$ \\
\hline Income squared /100 & $\begin{array}{l}-0.015 \\
(2.443)\end{array}$ & $\begin{array}{l}-0.001 \\
(0.128)\end{array}$ & $\begin{array}{l}-0.000 \\
(0.069)\end{array}$ & $\begin{array}{l}-0.001 \\
(0.091)\end{array}$ & $\begin{array}{l}-0.001 \\
(0.144)\end{array}$ & $\begin{array}{l}-0.001 \\
(0.152)\end{array}$ & $\begin{array}{l}-0.001 \\
(0.166)\end{array}$ & $\begin{array}{l}-0.001 \\
(0.178)\end{array}$ & $\begin{array}{l}-0.002 \\
(0.249)\end{array}$ \\
\hline Secondary education, base primary & $\begin{array}{l}2.307^{*} \\
(1.345)\end{array}$ & $\begin{array}{c}0.099^{*} \\
(0.058)\end{array}$ & $\begin{array}{l}0.064^{*} \\
(0.035)\end{array}$ & $\begin{array}{l}0.047^{*} \\
(0.027)\end{array}$ & $\begin{array}{c}0.039 \\
(0.025)\end{array}$ & $\begin{array}{c}0.019 \\
(0.022)\end{array}$ & $\begin{array}{c}0.029 \\
(0.021)\end{array}$ & $\begin{array}{c}0.017 \\
(0.021)\end{array}$ & $\begin{array}{c}0.009 \\
(0.021)\end{array}$ \\
\hline Tertiary education, base primary & $\begin{array}{l}-1.874 \\
(1.889)\end{array}$ & $\begin{array}{l}-0.167^{*} \\
(0.088)\end{array}$ & $\begin{array}{c}-0.174^{* * *} \\
(0.058)\end{array}$ & $\begin{array}{c}-0.122^{* * *} \\
(0.047)\end{array}$ & $\begin{array}{c}-0.104^{* *} \\
(0.043)\end{array}$ & $\begin{array}{c}-0.066^{*} \\
(0.039)\end{array}$ & $\begin{array}{c}-0.096^{* *} \\
(0.039)\end{array}$ & $\begin{array}{c}-0.087^{* *} \\
(0.039)\end{array}$ & $\begin{array}{l}-0.049 \\
(0.041)\end{array}$ \\
\hline Training in education, base general programmes & $\begin{array}{c}-2.096^{* *} \\
(0.860)\end{array}$ & $\begin{array}{l}-0.018 \\
(0.092)\end{array}$ & $\begin{array}{c}0.002 \\
(0.052)\end{array}$ & $\begin{array}{c}0.014 \\
(0.046)\end{array}$ & $\begin{array}{c}0.029 \\
(0.045)\end{array}$ & $\begin{array}{l}-0.005 \\
(0.041)\end{array}$ & $\begin{array}{c}0.046 \\
(0.032)\end{array}$ & $\begin{array}{c}0.055 \\
(0.034)\end{array}$ & $\begin{array}{c}0.070^{* * * *} \\
(0.023)\end{array}$ \\
\hline Training in humanities, base general programmes & $\begin{array}{l}-0.487 \\
(0.448)\end{array}$ & $\begin{array}{l}-0.011 \\
(0.021)\end{array}$ & $\begin{array}{c}0.026 \\
(0.017)\end{array}$ & $\begin{array}{c}0.012 \\
(0.013)\end{array}$ & $\begin{array}{c}0.011 \\
(0.011)\end{array}$ & $\begin{array}{c}0.000 \\
(0.010)\end{array}$ & $\begin{array}{l}-0.004 \\
(0.011)\end{array}$ & $\begin{array}{l}-0.001 \\
(0.012)\end{array}$ & $\begin{array}{c}0.002 \\
(0.014)\end{array}$ \\
\hline Training in social sciences, base general programmes & $\begin{array}{l}-0.164 \\
(2.015)\end{array}$ & $\begin{array}{l}-0.006 \\
(0.084)\end{array}$ & $\begin{array}{c}0.009 \\
(0.048)\end{array}$ & $\begin{array}{c}0.007 \\
(0.040)\end{array}$ & $\begin{array}{l}-0.001 \\
(0.037)\end{array}$ & $\begin{array}{l}-0.025 \\
(0.035)\end{array}$ & $\begin{array}{l}-0.014 \\
(0.036)\end{array}$ & $\begin{array}{c}0.008 \\
(0.036)\end{array}$ & $\begin{array}{l}-0.002 \\
(0.038)\end{array}$ \\
\hline Training in science, base general programmes & $\begin{array}{l}-0.191 \\
(0.403)\end{array}$ & $\begin{array}{c}0.001 \\
(0.009)\end{array}$ & $\begin{array}{c}0.002 \\
(0.006)\end{array}$ & $\begin{array}{c}0.000 \\
(0.004)\end{array}$ & $\begin{array}{c}0.000 \\
(0.003)\end{array}$ & $\begin{array}{l}-0.000 \\
(0.003)\end{array}$ & $\begin{array}{l}-0.001 \\
(0.004)\end{array}$ & $\begin{array}{l}-0.001 \\
(0.004)\end{array}$ & $\begin{array}{l}-0.003 \\
(0.009)\end{array}$ \\
\hline Training in engineering, base general programmes & $\begin{array}{l}3.580^{* *} \\
(1.466)\end{array}$ & $\begin{array}{c}0.110 \\
(0.075)\end{array}$ & $\begin{array}{c}0.027 \\
(0.045)\end{array}$ & $\begin{array}{c}0.030 \\
(0.037)\end{array}$ & $\begin{array}{c}0.024 \\
(0.034)\end{array}$ & $\begin{array}{c}0.045 \\
(0.033)\end{array}$ & $\begin{array}{c}0.029 \\
(0.032)\end{array}$ & $\begin{array}{c}0.036 \\
(0.031)\end{array}$ & $\begin{array}{c}0.055 \\
(0.036)\end{array}$ \\
\hline
\end{tabular}




\begin{tabular}{|c|c|c|c|c|c|c|c|c|c|}
\hline Training in agriculture, base general programmes & $\begin{array}{l}-0.023 \\
(0.226)\end{array}$ & $\begin{array}{l}-0.000 \\
(0.007)\end{array}$ & $\begin{array}{c}0.000 \\
(0.006)\end{array}$ & $\begin{array}{c}0.000 \\
(0.004)\end{array}$ & $\begin{array}{c}0.000 \\
(0.003)\end{array}$ & $\begin{array}{c}0.000 \\
(0.003)\end{array}$ & $\begin{array}{l}-0.000 \\
(0.003)\end{array}$ & $\begin{array}{l}-0.000 \\
(0.005)\end{array}$ & $\begin{array}{l}-0.001 \\
(0.008)\end{array}$ \\
\hline \multirow[t]{2}{*}{ Training in health, base general programmes } & -0.806 & -0.051 & -0.024 & $-0.038^{*}$ & -0.030 & -0.031 & -0.039 & 0.003 & 0.002 \\
\hline & $(0.924)$ & $(0.040)$ & $(0.023)$ & $(0.020)$ & $(0.022)$ & $(0.025)$ & $(0.027)$ & $(0.029)$ & $(0.038)$ \\
\hline \multirow[t]{2}{*}{ Training in services, base general programmes } & 0.582 & 0.035 & -0.007 & -0.018 & -0.018 & -0.002 & -0.018 & -0.022 & -0.013 \\
\hline & $(0.605)$ & $(0.031)$ & $(0.021)$ & $(0.018)$ & $(0.017)$ & $(0.015)$ & $(0.015)$ & $(0.015)$ & $(0.014)$ \\
\hline \multirow[t]{2}{*}{ Age } & $11.517^{* * *}$ & $0.638^{* * *}$ & $0.349^{* * *}$ & $0.307^{* * *}$ & $0.193^{*}$ & $0.252^{* * *}$ & 0.141 & 0.039 & 0.108 \\
\hline & $(5.470)$ & $(0.289)$ & $(0.163)$ & $(0.140)$ & $(0.104)$ & $(0.119)$ & $(0.090)$ & $(0.071)$ & $(0.089)$ \\
\hline \multirow[t]{2}{*}{ Age squared / 100} & $-8.332^{*}$ & $-0.513^{* *}$ & $-0.251^{*}$ & $-0.229^{*}$ & -0.124 & $-0.201^{*}$ & -0.093 & -0.015 & -0.097 \\
\hline & $(4.321)$ & $(0.252)$ & $(0.135)$ & $(0.119)$ & $(0.088)$ & $(0.107)$ & $(0.081)$ & $(0.071)$ & $(0.087)$ \\
\hline \multirow[t]{2}{*}{ Immigrant, base born in Estonia } & -0.098 & -0.001 & -0.004 & -0.005 & -0.006 & -0.004 & -0.005 & -0.003 & -0.004 \\
\hline & $(0.231)$ & $(0.008)$ & $(0.009)$ & $(0.009)$ & $(0.011)$ & $(0.008)$ & $(0.009)$ & $(0.006)$ & $(0.008)$ \\
\hline \multicolumn{10}{|l|}{ The unexplained gap } \\
\hline \multirow[t]{2}{*}{ Total } & -3.650 & 0.282 & 0.142 & 0.151 & 0.051 & 0.098 & 0.135 & 0.062 & 0.024 \\
\hline & $(5.259)$ & $(0.286)$ & $(0.155)$ & $(0.124)$ & $(0.113)$ & $(0.106)$ & $(0.100)$ & $(0.102)$ & $(0.110)$ \\
\hline \multirow[t]{2}{*}{ Status self-employed, base employee } & 0.273 & 0.041 & 0.011 & 0.007 & $0.023^{*}$ & 0.019 & $0.041^{* * * *}$ & $0.026^{*}$ & 0.001 \\
\hline & $(0.454)$ & $(0.035)$ & $(0.017)$ & $(0.013)$ & $(0.013)$ & $(0.013)$ & $(0.014)$ & $(0.015)$ & $(0.019)$ \\
\hline \multirow[t]{2}{*}{ Status unemployed, base employee } & -1.288 & -0.039 & -0.012 & -0.026 & 0.013 & 0.008 & 0.008 & 0.009 & $0.014^{*}$ \\
\hline & $(0.935)$ & $(0.052)$ & $(0.029)$ & $(0.022)$ & $(0.018)$ & $(0.017)$ & $(0.014)$ & $(0.011)$ & $(0.008)$ \\
\hline \multirow[t]{2}{*}{ Status other inactive, base employee } & -2.431 & -0.040 & $-0.130^{*}$ & -0.070 & -0.023 & 0.000 & -0.007 & 0.023 & 0.042 \\
\hline & $(2.442)$ & $(0.134)$ & $(0.075)$ & $(0.057)$ & $(0.050)$ & (0.047) & $(0.044)$ & $(0.046)$ & $(0.057)$ \\
\hline \multirow[t]{2}{*}{ Status retiree, base employee } & -0.152 & -0.232 & -0.117 & -0.040 & -0.051 & -0.085 & -0.081 & -0.102 & 0.061 \\
\hline & $(2.604)$ & $(0.204)$ & (0.119) & $(0.100)$ & (0.090) & $(0.086)$ & $(0.087)$ & $(0.092)$ & $(0.105)$ \\
\hline \multirow[t]{2}{*}{ Time in employment } & 20.002 & -0.479 & -0.741 & -0.089 & 0.066 & $-1.063^{*}$ & -0.249 & 0.180 & 0.766 \\
\hline & $(19.846)$ & $(1.669)$ & $(0.915)$ & $(0.719)$ & $(0.652)$ & $(0.641)$ & $(0.646)$ & $(0.635)$ & $(0.647)$ \\
\hline \multirow[t]{2}{*}{ Time in employment squared / 100} & -6.751 & 0.545 & 0.594 & 0.184 & 0.129 & $0.820^{* *}$ & 0.330 & 0.010 & -0.402 \\
\hline & $(12.500)$ & $(1.021)$ & $(0.571)$ & $(0.458)$ & $(0.411)$ & $(0.402)$ & $(0.408)$ & $(0.425)$ & $(0.425)$ \\
\hline \multirow[t]{2}{*}{ Income, thousand EUR } & 4.363 & -0.202 & -0.153 & -0.077 & -0.000 & -0.076 & -0.052 & -0.075 & 0.067 \\
\hline & $(4.032)$ & $(0.217)$ & $(0.117)$ & $(0.085)$ & $(0.076)$ & $(0.084)$ & $(0.078)$ & $(0.085)$ & $(0.141)$ \\
\hline \multirow[t]{2}{*}{ Income squared /100 } & -1.420 & 0.067 & 0.051 & 0.025 & 0.000 & 0.025 & 0.019 & 0.027 & -0.019 \\
\hline & $(2.715)$ & $(0.140)$ & $(0.087)$ & $(0.054)$ & $(0.040)$ & $(0.053)$ & $(0.047)$ & $(0.055)$ & $(0.076)$ \\
\hline \multirow{2}{*}{ Secondary education, base primary } & 5.121 & 0.362 & 0.137 & 0.195 & 0.070 & -0.019 & 0.072 & 0.053 & -0.038 \\
\hline & $(7.756)$ & $(0.418)$ & $(0.225)$ & $(0.166)$ & $(0.140)$ & $(0.127)$ & $(0.122)$ & $(0.121)$ & $(0.111)$ \\
\hline \multirow[t]{2}{*}{ Tertiary education, base primary } & -0.450 & 0.308 & 0.226 & 0.206 & 0.073 & -0.018 & 0.180 & 0.161 & -0.090 \\
\hline & $(9.412)$ & $(0.536)$ & $(0.291)$ & $(0.223)$ & $(0.190)$ & $(0.177)$ & $(0.172)$ & $(0.172)$ & $(0.172)$ \\
\hline \multirow[t]{2}{*}{ Training in education, base general programmes } & 2.234 & 0.031 & -0.002 & -0.028 & -0.013 & 0.018 & -0.065 & -0.050 & $-0.056^{*}$ \\
\hline & $(1.552)$ & $(0.136)$ & $(0.074)$ & $(0.062)$ & $(0.059)$ & $(0.055)$ & $(0.046)$ & $(0.046)$ & $(0.034)$ \\
\hline \multirow[t]{2}{*}{ Training in humanities, base general programmes } & 0.016 & -0.024 & $-0.089^{* *}$ & $-0.057^{*}$ & -0.038 & -0.020 & -0.014 & -0.037 & -0.041 \\
\hline & (1.036) & $(0.067)$ & $(0.040)$ & $(0.032)$ & $(0.028)$ & $(0.026)$ & $(0.027)$ & $(0.029)$ & (0.035) \\
\hline
\end{tabular}




\begin{tabular}{|c|c|c|c|c|c|c|c|c|c|}
\hline Training in social sciences, base general programmes & $\begin{array}{l}-0.139 \\
(3.906)\end{array}$ & $\begin{array}{l}-0.007 \\
(0.202)\end{array}$ & $\begin{array}{c}-0.094 \\
(0.110)\end{array}$ & $\begin{array}{l}-0.111 \\
(0.086)\end{array}$ & $\begin{array}{l}-0.045 \\
(0.076)\end{array}$ & $\begin{array}{c}0.032 \\
(0.071)\end{array}$ & $\begin{array}{c}0.007 \\
(0.071)\end{array}$ & $\begin{array}{l}-0.028 \\
(0.071)\end{array}$ & $\begin{array}{c}0.022 \\
(0.074)\end{array}$ \\
\hline \multirow[t]{2}{*}{ Training in science, base general programmes } & 0.021 & -0.072 & $-0.048^{* *}$ & -0.013 & -0.005 & 0.003 & 0.001 & 0.010 & 0.030 \\
\hline & $(0.546)$ & $(0.046)$ & $(0.025)$ & $(0.017)$ & $(0.015)$ & $(0.013)$ & $(0.014)$ & $(0.015)$ & $(0.022)$ \\
\hline \multirow[t]{2}{*}{ Training in engineering, base general programmes } & 1.941 & 0.004 & -0.077 & -0.048 & -0.011 & 0.016 & -0.014 & -0.044 & -0.003 \\
\hline & $(1.947)$ & $(0.122)$ & $(0.067)$ & $(0.053)$ & $(0.046)$ & $(0.043)$ & $(0.043)$ & $(0.045)$ & $(0.047)$ \\
\hline \multirow[t]{2}{*}{ Training in agriculture, base general programmes } & 1.101 & 0.070 & 0.003 & 0.002 & 0.017 & -0.001 & 0.007 & 0.009 & 0.032 \\
\hline & $(0.676)$ & $(0.059)$ & $(0.031)$ & $(0.024)$ & $(0.021)$ & $(0.019)$ & (0.019) & $(0.020)$ & $(0.024)$ \\
\hline \multirow[t]{2}{*}{ Training in health, base general programmes } & -0.010 & -0.002 & -0.025 & 0.033 & 0.047 & 0.059 & 0.061 & 0.017 & 0.017 \\
\hline & (1.406) & $(0.075)$ & $(0.041)$ & $(0.035)$ & $(0.034)$ & $(0.037)$ & $(0.037)$ & $(0.040)$ & $(0.051)$ \\
\hline \multirow[t]{2}{*}{ Training in services, base general programmes } & -0.427 & -0.034 & -0.044 & $-0.048^{*}$ & -0.029 & -0.008 & $-0.030^{*}$ & $-0.030^{*}$ & -0.033 \\
\hline & $(0.960)$ & $(0.058)$ & $(0.032)$ & $(0.025)$ & $(0.021)$ & $(0.017)$ & $(0.017)$ & $(0.018)$ & $(0.021)$ \\
\hline \multirow[t]{2}{*}{ Age } & -192.960 & -10.631 & -2.852 & -1.362 & -3.242 & 0.244 & -2.879 & $-4.028^{*}$ & -2.671 \\
\hline & $(128.663)$ & $(7.287)$ & $(3.651)$ & $(2.787)$ & $(2.449)$ & $(2.352)$ & $(2.339)$ & $(2.223)$ & $(2.393)$ \\
\hline \multirow[t]{2}{*}{ Age squared / 100} & 90.571 & 5.212 & 1.406 & 0.464 & 1.544 & -0.236 & 1.522 & $2.167^{*}$ & 1.288 \\
\hline & $(61.599)$ & $(3.755)$ & $(1.901)$ & $(1.485)$ & $(1.315)$ & $(1.275)$ & $(1.271)$ & $(1.220)$ & $(1.282)$ \\
\hline \multirow[t]{2}{*}{ Immigrant, base born in Estonia } & -1.518 & $-0.178^{*}$ & -0.052 & -0.032 & -0.035 & 0.041 & 0.025 & 0.039 & 0.033 \\
\hline & (1.634) & $(0.094)$ & $(0.059)$ & $(0.047)$ & $(0.043)$ & $(0.041)$ & $(0.038)$ & $(0.038)$ & $(0.035)$ \\
\hline \multirow{2}{*}{ Constant } & 78.254 & 5.580 & 2.149 & 1.034 & 1.562 & 0.337 & 1.253 & $1.726^{*}$ & 1.007 \\
\hline & $(69.241)$ & $(3.436)$ & $(1.686)$ & $(1.247)$ & $(1.054)$ & $(0.976)$ & $(0.954)$ & $(0.939)$ & $(1.059)$ \\
\hline$N$ & 1576 & 1576 & 1576 & 1576 & 1576 & 1576 & 1576 & 1576 & 1576 \\
\hline
\end{tabular}

Source: Authors' calculations from the Estonian HFCS.

Notes: Standard errors in parentheses. ${ }^{*},{ }^{* *},{ }^{* * *}$ refer to statistical significance at $10 \%, 5 \%$ and $1 \%$ level. 
Appendix 8: Results of the detailed decomposition of the gender wealth gaps over quantiles of net wealth, household with cohabiting partners

\begin{tabular}{|c|c|c|c|c|c|c|c|c|c|}
\hline & $\begin{array}{c}10^{\text {th }} \\
\text { quantile }\end{array}$ & $\begin{array}{c}2^{\text {th }} \\
\text { quantile }\end{array}$ & $\begin{array}{c}\text { 30 }^{\text {th }} \\
\text { quantile }\end{array}$ & $\begin{array}{c}\mathbf{4 0}^{\text {th }} \\
\text { quantile }\end{array}$ & $\begin{array}{c}\mathbf{5 0}^{\text {th }} \\
\text { quantile }\end{array}$ & $\begin{array}{c}\mathbf{6 0}^{\text {th }} \\
\text { quantile }\end{array}$ & $\begin{array}{c}\mathbf{7 0}^{\text {th }} \\
\text { quantile }\end{array}$ & $\begin{array}{c}\mathbf{8 0}^{\text {th }} \\
\text { quantile }\end{array}$ & $\begin{array}{c}\mathbf{9 0}^{\text {th }} \\
\text { quantile }\end{array}$ \\
\hline \multicolumn{10}{|l|}{ The explained gap } \\
\hline Total & $\begin{array}{l}-0.586 \\
(0.970)\end{array}$ & $\begin{array}{l}2.618^{* *} \\
(1.103)\end{array}$ & $\begin{array}{l}2.496^{* *} \\
(1.144)\end{array}$ & $\begin{array}{c}0.489 \\
(0.397)\end{array}$ & $\begin{array}{l}0.613^{* *} \\
(0.287)\end{array}$ & $\begin{array}{c}0.279 \\
(0.245)\end{array}$ & $\begin{array}{c}0.255 \\
(0.231)\end{array}$ & $\begin{array}{c}0.207 \\
(0.233)\end{array}$ & $\begin{array}{c}0.317 \\
(0.227)\end{array}$ \\
\hline Status self-employed, base employee & $\begin{array}{c}0.206 \\
(0.161)\end{array}$ & $\begin{array}{l}0.358^{* *} \\
(0.173)\end{array}$ & $\begin{array}{c}0.355 \\
(0.256)\end{array}$ & $\begin{array}{c}0.168^{*} \\
(0.091)\end{array}$ & $\begin{array}{l}0.143^{* *} \\
(0.069)\end{array}$ & $\begin{array}{c}0.083 \\
(0.060)\end{array}$ & $\begin{array}{l}0.130^{* *} \\
(0.064)\end{array}$ & $\begin{array}{c}0.110^{*} \\
(0.059)\end{array}$ & $\begin{array}{l}0.152^{* *} \\
(0.069)\end{array}$ \\
\hline Status unemployed, base employee & $\begin{array}{l}-0.001 \\
(0.081)\end{array}$ & $\begin{array}{c}0.047 \\
(0.091)\end{array}$ & $\begin{array}{c}0.026 \\
(0.117)\end{array}$ & $\begin{array}{l}-0.000 \\
(0.044)\end{array}$ & $\begin{array}{c}0.016 \\
(0.035)\end{array}$ & $\begin{array}{c}0.017 \\
(0.032)\end{array}$ & $\begin{array}{c}0.041 \\
(0.047)\end{array}$ & $\begin{array}{c}0.003 \\
(0.019)\end{array}$ & $\begin{array}{c}0.008 \\
(0.013)\end{array}$ \\
\hline Status other inactive, base employee & $\begin{array}{c}0.086 \\
(0.293)\end{array}$ & $\begin{array}{c}0.241 \\
(0.459)\end{array}$ & $\begin{array}{c}0.985 \\
(0.639)\end{array}$ & $\begin{array}{c}0.276 \\
(0.206)\end{array}$ & $\begin{array}{c}0.217 \\
(0.144)\end{array}$ & $\begin{array}{c}0.150 \\
(0.125)\end{array}$ & $\begin{array}{c}0.020 \\
(0.103)\end{array}$ & $\begin{array}{c}0.003 \\
(0.107)\end{array}$ & $\begin{array}{l}-0.060 \\
(0.111)\end{array}$ \\
\hline Status retiree, base employee & $\begin{array}{l}-0.046 \\
(0.104)\end{array}$ & $\begin{array}{l}-0.082 \\
(0.156)\end{array}$ & $\begin{array}{l}-0.079 \\
(0.175)\end{array}$ & $\begin{array}{l}-0.030 \\
(0.063)\end{array}$ & $\begin{array}{l}-0.015 \\
(0.042)\end{array}$ & $\begin{array}{l}-0.007 \\
(0.034)\end{array}$ & $\begin{array}{c}0.001 \\
(0.028)\end{array}$ & $\begin{array}{l}-0.009 \\
(0.027)\end{array}$ & $\begin{array}{l}-0.015 \\
(0.031)\end{array}$ \\
\hline Time in employment & $\begin{array}{c}-2.203^{* *} \\
(1.093)\end{array}$ & $\begin{array}{c}-2.315^{* *} \\
(1.124)\end{array}$ & $\begin{array}{c}-3.313^{* *} \\
(1.646)\end{array}$ & $\begin{array}{c}-1.593^{* *} \\
(0.624)\end{array}$ & $\begin{array}{c}-0.998^{* *} \\
(0.459)\end{array}$ & $\begin{array}{c}-0.733^{*} \\
(0.404)\end{array}$ & $\begin{array}{l}-0.489 \\
(0.379)\end{array}$ & $\begin{array}{l}-0.590 \\
(0.408)\end{array}$ & $\begin{array}{c}0.128 \\
(0.235)\end{array}$ \\
\hline Time in employment squared / 100 & $\begin{array}{c}0.979 \\
(0.647)\end{array}$ & $\begin{array}{c}1.144 \\
(0.726)\end{array}$ & $\begin{array}{c}1.741 \\
(1.113)\end{array}$ & $\begin{array}{c}0.781^{*} \\
(0.434)\end{array}$ & $\begin{array}{c}0.615^{*} \\
(0.326)\end{array}$ & $\begin{array}{c}0.461^{*} \\
(0.278)\end{array}$ & $\begin{array}{c}0.359 \\
(0.254)\end{array}$ & $\begin{array}{c}0.377 \\
(0.264)\end{array}$ & $\begin{array}{l}-0.093 \\
(0.147)\end{array}$ \\
\hline Income, thousand EUR & $\begin{array}{c}-0.979^{* * *} \\
(0.476)\end{array}$ & $\begin{array}{c}-0.963^{* * *} \\
(0.487)\end{array}$ & $\begin{array}{l}1.082^{*} \\
(0.612)\end{array}$ & $\begin{array}{c}0.330^{*} \\
(0.200)\end{array}$ & $\begin{array}{c}0.243^{*} \\
(0.141)\end{array}$ & $\begin{array}{c}0.230^{*} \\
(0.127)\end{array}$ & $\begin{array}{l}0.271^{* *} \\
(0.124)\end{array}$ & $\begin{array}{l}0.236^{* * *} \\
(0.109)\end{array}$ & $\begin{array}{c}0.179^{*} \\
(0.096)\end{array}$ \\
\hline Income squared /100 & $\begin{array}{c}0.484 \\
(0.348)\end{array}$ & $\begin{array}{c}0.515 \\
(0.350)\end{array}$ & $\begin{array}{l}-0.568 \\
(0.399)\end{array}$ & $\begin{array}{l}-0.165 \\
(0.129)\end{array}$ & $\begin{array}{l}-0.090 \\
(0.085)\end{array}$ & $\begin{array}{l}-0.104 \\
(0.084)\end{array}$ & $\begin{array}{l}-0.106 \\
(0.078)\end{array}$ & $\begin{array}{l}-0.100 \\
(0.066)\end{array}$ & $\begin{array}{l}-0.070 \\
(0.058)\end{array}$ \\
\hline Secondary education, base primary & $\begin{array}{c}0.014 \\
(0.278)\end{array}$ & $\begin{array}{c}0.032 \\
(0.324)\end{array}$ & $\begin{array}{l}-0.129 \\
(0.400)\end{array}$ & $\begin{array}{l}-0.040 \\
(0.139)\end{array}$ & $\begin{array}{c}0.089 \\
(0.103)\end{array}$ & $\begin{array}{c}0.109 \\
(0.092)\end{array}$ & $\begin{array}{c}0.144^{*} \\
(0.079)\end{array}$ & $\begin{array}{l}0.126^{*} \\
(0.069)\end{array}$ & $\begin{array}{c}0.060 \\
(0.048)\end{array}$ \\
\hline Tertiary education, base primary & $\begin{array}{l}-0.350 \\
(0.515)\end{array}$ & $\begin{array}{l}-0.648 \\
(0.577)\end{array}$ & $\begin{array}{c}0.316 \\
(0.712)\end{array}$ & $\begin{array}{l}-0.142 \\
(0.256)\end{array}$ & $\begin{array}{l}-0.193 \\
(0.182)\end{array}$ & $\begin{array}{l}-0.228 \\
(0.159)\end{array}$ & $\begin{array}{c}-0.324^{* *} \\
(0.147)\end{array}$ & $\begin{array}{c}-0.374^{* * * *} \\
(0.145)\end{array}$ & $\begin{array}{c}-0.223^{*} \\
(0.124)\end{array}$ \\
\hline Training in education, base general programmes & $\begin{array}{c}0.288 \\
(0.358)\end{array}$ & $\begin{array}{c}0.254 \\
(0.339)\end{array}$ & $\begin{array}{l}-0.369 \\
(0.393)\end{array}$ & $\begin{array}{l}-0.085 \\
(0.130)\end{array}$ & $\begin{array}{l}-0.079 \\
(0.093)\end{array}$ & $\begin{array}{l}-0.102 \\
(0.085)\end{array}$ & $\begin{array}{l}-0.120 \\
(0.087)\end{array}$ & $\begin{array}{c}0.028 \\
(0.129)\end{array}$ & $\begin{array}{l}-0.079 \\
(0.139)\end{array}$ \\
\hline Training in humanities, base general programmes & $\begin{array}{c}0.033 \\
(0.068)\end{array}$ & $\begin{array}{c}0.003 \\
(0.070)\end{array}$ & $\begin{array}{c}0.075 \\
(0.142)\end{array}$ & $\begin{array}{c}0.010 \\
(0.033)\end{array}$ & $\begin{array}{l}-0.011 \\
(0.032)\end{array}$ & $\begin{array}{l}-0.004 \\
(0.024)\end{array}$ & $\begin{array}{l}-0.007 \\
(0.022)\end{array}$ & $\begin{array}{l}-0.012 \\
(0.028)\end{array}$ & $\begin{array}{l}-0.007 \\
(0.020)\end{array}$ \\
\hline Training in social sciences, base general programmes & $\begin{array}{c}0.442 \\
(0.744)\end{array}$ & $\begin{array}{c}0.860 \\
(0.711)\end{array}$ & $\begin{array}{l}-0.572 \\
(0.765)\end{array}$ & $\begin{array}{l}-0.064 \\
(0.252)\end{array}$ & $\begin{array}{c}0.123 \\
(0.174)\end{array}$ & $\begin{array}{c}0.071 \\
(0.158)\end{array}$ & $\begin{array}{c}0.087 \\
(0.148)\end{array}$ & $\begin{array}{c}0.263^{*} \\
(0.143)\end{array}$ & $\begin{array}{c}0.187 \\
(0.126)\end{array}$ \\
\hline Training in science, base general programmes & $\begin{array}{l}-0.100 \\
(0.156)\end{array}$ & $\begin{array}{l}-0.120 \\
(0.167)\end{array}$ & $\begin{array}{c}0.076 \\
(0.149)\end{array}$ & $\begin{array}{c}0.012 \\
(0.052)\end{array}$ & $\begin{array}{c}0.021 \\
(0.042)\end{array}$ & $\begin{array}{c}0.016 \\
(0.038)\end{array}$ & $\begin{array}{l}-0.011 \\
(0.035)\end{array}$ & $\begin{array}{l}-0.033 \\
(0.038)\end{array}$ & $\begin{array}{l}-0.021 \\
(0.025)\end{array}$ \\
\hline Training in engineering, base general programmes & $\begin{array}{c}0.344 \\
(0.499)\end{array}$ & $\begin{array}{l}-0.208 \\
(0.565)\end{array}$ & $\begin{array}{c}0.761 \\
(0.705)\end{array}$ & $\begin{array}{c}0.090 \\
(0.235)\end{array}$ & $\begin{array}{l}-0.067 \\
(0.167)\end{array}$ & $\begin{array}{l}-0.069 \\
(0.147)\end{array}$ & $\begin{array}{l}-0.070 \\
(0.137)\end{array}$ & $\begin{array}{l}-0.157 \\
(0.127)\end{array}$ & $\begin{array}{l}-0.010 \\
(0.122)\end{array}$ \\
\hline
\end{tabular}




\begin{tabular}{|c|c|c|c|c|c|c|c|c|c|}
\hline Training in agriculture, base general programmes & $\begin{array}{l}-0.000 \\
(0.046)\end{array}$ & $\begin{array}{l}-0.000 \\
(0.046)\end{array}$ & $\begin{array}{l}-0.002 \\
(0.168)\end{array}$ & $\begin{array}{l}-0.000 \\
(0.041)\end{array}$ & $\begin{array}{l}-0.000 \\
(0.019)\end{array}$ & $\begin{array}{l}-0.000 \\
(0.017)\end{array}$ & $\begin{array}{l}-0.000 \\
(0.016)\end{array}$ & $\begin{array}{c}0.000 \\
(0.015)\end{array}$ & $\begin{array}{l}-0.000 \\
(0.019)\end{array}$ \\
\hline \multirow[t]{2}{*}{ Training in health, base general programmes } & $-0.454^{*}$ & $2.893^{* * *}$ & $1.099^{* *}$ & $0.350^{* *}$ & $0.203^{*}$ & 0.138 & $0.139^{*}$ & 0.126 & 0.087 \\
\hline & $(0.236)$ & $(0.617)$ & $(0.477)$ & $(0.155)$ & $(0.104)$ & $(0.089)$ & $(0.077)$ & $(0.078)$ & $(0.080)$ \\
\hline \multirow[t]{2}{*}{ Training in services, base general programmes } & 0.002 & 0.002 & 0.012 & 0.002 & 0.002 & 0.000 & -0.001 & -0.002 & -0.001 \\
\hline & $(0.053)$ & $(0.065)$ & $(0.159)$ & $(0.034)$ & $(0.029)$ & $(0.018)$ & $(0.020)$ & $(0.029)$ & $(0.017)$ \\
\hline \multirow[t]{2}{*}{ Age } & 0.991 & 0.697 & 1.755 & $1.595^{*}$ & $1.262^{*}$ & 0.815 & 0.549 & 0.476 & 0.038 \\
\hline & $(0.999)$ & $(0.984)$ & $(1.697)$ & $(0.945)$ & $(0.739)$ & $(0.531)$ & $(0.433)$ & $(0.415)$ & $(0.227)$ \\
\hline \multirow[t]{2}{*}{ Age squared / 100} & -0.313 & -0.067 & -0.766 & -1.038 & -0.898 & -0.578 & -0.388 & -0.292 & 0.041 \\
\hline & $(0.802)$ & $(0.832)$ & $(1.402)$ & $(0.777)$ & $(0.637)$ & $(0.461)$ & $(0.370)$ & $(0.334)$ & $(0.208)$ \\
\hline \multirow[t]{2}{*}{ Immigrant, base born in Estonia } & -0.012 & -0.024 & 0.012 & 0.031 & 0.029 & 0.014 & 0.029 & 0.026 & 0.017 \\
\hline & $(0.065)$ & $(0.088)$ & $(0.109)$ & $(0.049)$ & $(0.042)$ & $(0.028)$ & $(0.037)$ & $(0.033)$ & $(0.021)$ \\
\hline \multicolumn{10}{|l|}{ The unexplained gap } \\
\hline \multirow[t]{2}{*}{ Total } & 1.767 & $6.913^{* * * *}$ & 0.833 & 1.130 & -0.182 & 0.216 & -0.024 & -0.196 & 0.022 \\
\hline & $(1.238)$ & $(1.462)$ & $(1.914)$ & $(0.735)$ & $(0.456)$ & $(0.409)$ & $(0.369)$ & $(0.368)$ & $(0.308)$ \\
\hline \multirow[t]{2}{*}{ Status self-employed, base employee } & 0.124 & 0.172 & 0.044 & -0.060 & -0.055 & -0.104 & 0.046 & 0.081 & 0.068 \\
\hline & $(0.132)$ & $(0.185)$ & $(0.258)$ & $(0.110)$ & $(0.070)$ & $(0.068)$ & $(0.061)$ & $(0.051)$ & $(0.048)$ \\
\hline \multirow[t]{2}{*}{ Status unemployed, base employee } & -0.053 & 0.109 & 0.408 & 0.100 & 0.108 & 0.108 & 0.138 & 0.003 & -0.081 \\
\hline & $(0.219)$ & $(0.275)$ & $(0.466)$ & $(0.177)$ & $(0.113)$ & $(0.101)$ & $(0.105)$ & $(0.094)$ & $(0.092)$ \\
\hline \multirow[t]{2}{*}{ Status other inactive, base employee } & 0.060 & -0.759 & $-2.089^{*}$ & -0.574 & -0.241 & -0.086 & 0.159 & 0.123 & 0.154 \\
\hline & $(0.532)$ & $(0.839)$ & $(1.206)$ & $(0.439)$ & $(0.268)$ & $(0.228)$ & $(0.192)$ & $(0.190)$ & $(0.186)$ \\
\hline \multirow[t]{2}{*}{ Status retiree, base employee } & 0.017 & -0.503 & -0.775 & -0.367 & -0.170 & -0.097 & 0.039 & 0.143 & 0.205 \\
\hline & $(0.294)$ & $(0.442)$ & $(0.695)$ & $(0.314)$ & $(0.197)$ & $(0.187)$ & $(0.186)$ & $(0.173)$ & $(0.134)$ \\
\hline \multirow[t]{2}{*}{ Time in employment } & -3.489 & $-12.518^{* *}$ & -14.378 & $-7.734^{* * *}$ & $-4.815^{* *}$ & $-4.375^{* *}$ & $-3.742^{*}$ & -3.044 & 1.718 \\
\hline & $(4.197)$ & $(5.531)$ & $(8.840)$ & $(3.485)$ & $(2.257)$ & $(2.080)$ & $(1.985)$ & $(2.047)$ & $(1.331)$ \\
\hline \multirow[t]{2}{*}{ Time in employment squared / 100} & 0.542 & $5.376^{*}$ & 5.487 & 2.704 & 1.641 & 1.549 & 1.301 & 1.224 & $-1.324^{*}$ \\
\hline & $(1.905)$ & $(2.749)$ & $(4.502)$ & $(1.846)$ & $(1.154)$ & $(1.087)$ & $(1.052)$ & $(1.042)$ & $(0.698)$ \\
\hline \multirow[t]{2}{*}{ Income, thousand EUR } & -2.019 & 0.521 & $5.135^{*}$ & 1.121 & 0.512 & 0.632 & 0.777 & $1.396^{* * *}$ & 0.669 \\
\hline & $(1.467)$ & $(1.824)$ & (2.677) & $(1.105)$ & $(0.661)$ & $(0.592)$ & $(0.575)$ & $(0.566)$ & $(0.478)$ \\
\hline \multirow[t]{2}{*}{ Income squared /100 } & 0.274 & -0.471 & $-1.321^{*}$ & -0.303 & -0.132 & -0.238 & -0.252 & $-0.472^{* * * *}$ & $-0.297^{* *}$ \\
\hline & $(0.443)$ & $(0.533)$ & $(0.734)$ & $(0.296)$ & $(0.176)$ & $(0.164)$ & $(0.164)$ & $(0.172)$ & $(0.151)$ \\
\hline \multirow[t]{2}{*}{ Secondary education, base primary } & 0.117 & 2.101 & -0.613 & -1.142 & -0.266 & 0.432 & 0.636 & 0.326 & 0.107 \\
\hline & $(1.306)$ & $(1.775)$ & $(2.725)$ & $(1.075)$ & $(0.597)$ & $(0.506)$ & $(0.415)$ & $(0.351)$ & $(0.244)$ \\
\hline \multirow[t]{2}{*}{ Tertiary education, base primary } & 0.910 & $3.457^{*}$ & -2.648 & $-2.361^{*}$ & -0.949 & -0.225 & 0.200 & -0.109 & -0.165 \\
\hline & $(1.666)$ & $(2.099)$ & $(3.121)$ & $(1.297)$ & $(0.750)$ & $(0.644)$ & $(0.570)$ & $(0.497)$ & $(0.418)$ \\
\hline
\end{tabular}




\begin{tabular}{|c|c|c|c|c|c|c|c|c|c|}
\hline Training in education, base general programmes & $\begin{array}{l}-0.380 \\
(0.435)\end{array}$ & $\begin{array}{l}-0.211 \\
(0.465)\end{array}$ & $\begin{array}{c}0.528 \\
(0.586)\end{array}$ & $\begin{array}{c}0.282 \\
(0.221)\end{array}$ & $\begin{array}{c}0.202 \\
(0.142)\end{array}$ & $\begin{array}{c}0.154 \\
(0.124)\end{array}$ & $\begin{array}{c}0.129 \\
(0.121)\end{array}$ & $\begin{array}{c}0.016 \\
(0.163)\end{array}$ & $\begin{array}{c}0.125 \\
(0.172)\end{array}$ \\
\hline \multirow[t]{2}{*}{ Training in humanities, base general programmes } & 0.103 & 0.002 & 0.200 & 0.107 & 0.006 & -0.019 & -0.046 & 0.000 & -0.002 \\
\hline & $(0.104)$ & $(0.217)$ & $(0.259)$ & $(0.108)$ & $(0.069)$ & $(0.063)$ & $(0.061)$ & $(0.055)$ & $(0.050)$ \\
\hline \multirow{2}{*}{$\begin{array}{l}\text { Training in social sciences, base general } \\
\text { programmes }\end{array}$} & -0.929 & $-2.391^{*}$ & -0.489 & -0.115 & -0.344 & -0.435 & -0.436 & $-0.471^{*}$ & -0.049 \\
\hline & $(1.208)$ & $(1.273)$ & $(1.544)$ & $(0.619)$ & $(0.384)$ & $(0.344)$ & $(0.314)$ & $(0.280)$ & $(0.234)$ \\
\hline \multirow[t]{2}{*}{ Training in science, base general programmes } & 0.028 & -0.047 & $0.658^{*}$ & 0.208 & 0.121 & 0.087 & 0.012 & -0.013 & -0.007 \\
\hline & $(0.277)$ & $(0.298)$ & $(0.391)$ & $(0.150)$ & $(0.093)$ & $(0.077)$ & $(0.069)$ & $(0.049)$ & $(0.038)$ \\
\hline \multirow[t]{2}{*}{ Training in engineering, base general programmes } & 0.190 & -0.149 & 0.322 & 0.277 & 0.146 & 0.052 & 0.102 & 0.143 & 0.115 \\
\hline & $(0.290)$ & $(0.396)$ & $(0.606)$ & $(0.270)$ & $(0.161)$ & $(0.132)$ & $(0.106)$ & $(0.096)$ & $(0.086)$ \\
\hline \multirow[t]{2}{*}{ Training in agriculture, base general programmes } & -0.058 & -0.168 & 0.452 & 0.108 & -0.026 & -0.088 & -0.064 & -0.017 & -0.047 \\
\hline & $(0.138)$ & $(0.157)$ & $(0.307)$ & $(0.121)$ & $(0.072)$ & $(0.075)$ & $(0.075)$ & $(0.071)$ & $(0.078)$ \\
\hline \multirow[t]{2}{*}{ Training in health, base general programmes } & $0.806^{* *}$ & $-2.762^{* * * *}$ & -0.869 & -0.122 & -0.118 & -0.187 & -0.168 & -0.070 & -0.089 \\
\hline & $(0.378)$ & $(0.674)$ & $(0.701)$ & $(0.266)$ & $(0.164)$ & $(0.148)$ & $(0.134)$ & $(0.124)$ & $(0.121)$ \\
\hline \multirow[t]{2}{*}{ Training in services, base general programmes } & 0.079 & 0.158 & 0.778 & 0.215 & 0.135 & -0.115 & -0.162 & -0.068 & -0.013 \\
\hline & $(0.270)$ & $(0.416)$ & $(0.612)$ & $(0.239)$ & $(0.143)$ & $(0.126)$ & $(0.117)$ & $(0.095)$ & $(0.078)$ \\
\hline \multirow[t]{2}{*}{ Age } & 18.437 & 3.227 & -4.449 & 2.999 & 8.046 & 6.334 & 4.756 & 3.368 & -5.380 \\
\hline & $(17.366)$ & $(21.333)$ & $(37.343)$ & $(14.386)$ & $(9.819)$ & $(8.940)$ & (8.919) & (8.994) & (4.808) \\
\hline \multirow[t]{2}{*}{ Age squared / 100} & -5.633 & 0.756 & 4.756 & -1.459 & -3.163 & -2.426 & -1.453 & -1.515 & 1.967 \\
\hline & $(8.138)$ & $(9.879)$ & $(17.364)$ & $(6.827)$ & $(4.744)$ & $(4.372)$ & $(4.460)$ & $(4.408)$ & $(2.327)$ \\
\hline \multirow{2}{*}{ Immigrant, base born in Estonia } & 0.153 & 0.183 & 0.544 & 0.124 & -0.046 & -0.088 & $-0.200^{*}$ & $-0.226^{* *}$ & 0.065 \\
\hline & $(0.249)$ & $(0.347)$ & $(0.541)$ & $(0.194)$ & $(0.126)$ & $(0.115)$ & $(0.110)$ & $(0.109)$ & $(0.059)$ \\
\hline \multirow[t]{2}{*}{ Constant } & -7.511 & 10.832 & 9.154 & 7.123 & -0.774 & -0.649 & -1.796 & -1.014 & 2.281 \\
\hline & $(8.924)$ & $(10.880)$ & $(18.592)$ & $(6.836)$ & $(4.498)$ & $(4.091)$ & $(3.989)$ & $(3.936)$ & $(2.204)$ \\
\hline$N$ & 749 & 749 & 749 & 749 & 749 & 749 & 749 & 749 & 749 \\
\hline
\end{tabular}

Source: Authors' calculations from the Estonian HFCS.

Notes: Standard errors in parentheses. ${ }^{*},{ }^{* *},{ }^{* * *}$ refer to statistical significance at $10 \%, 5 \%$ and $1 \%$ level. 
Appendix 9: Results of the detailed decomposition of the gender wealth gaps over quantiles of net wealth, other two adults or three or more adults

\begin{tabular}{|c|c|c|c|c|c|c|c|c|c|}
\hline & $\begin{array}{c}10^{\text {th }} \\
\text { quantile }\end{array}$ & $\begin{array}{c}2^{\text {th }} \\
\text { quantile }\end{array}$ & $\begin{array}{c}\mathbf{3 0}^{\text {th }} \\
\text { quantile }\end{array}$ & $\begin{array}{c}\mathbf{4 0}^{\text {th }} \\
\text { quantile }\end{array}$ & $\begin{array}{c}\mathbf{5 0}^{\text {th }} \\
\text { quantile }\end{array}$ & $\begin{array}{c}\mathbf{6 0}^{\text {th }} \\
\text { quantile }\end{array}$ & $\begin{array}{c}\mathbf{7 0}^{\text {th }} \\
\text { quantile }\end{array}$ & $\begin{array}{c}\mathbf{8 0}^{\text {th }} \\
\text { quantile }\end{array}$ & $\begin{array}{c}\mathbf{9 0}^{\text {th }} \\
\text { quantile }\end{array}$ \\
\hline \multicolumn{10}{|l|}{ The explained gap } \\
\hline Total & $\begin{array}{c}0.820 \\
(0.975)\end{array}$ & $\begin{array}{c}0.484 \\
(1.015)\end{array}$ & $\begin{array}{c}0.137 \\
(1.410)\end{array}$ & $\begin{array}{l}-0.032 \\
(0.583)\end{array}$ & $\begin{array}{l}-0.550 \\
(0.469)\end{array}$ & $\begin{array}{c}0.060 \\
(0.409)\end{array}$ & $\begin{array}{c}0.127 \\
(0.367)\end{array}$ & $\begin{array}{c}0.070 \\
(0.365)\end{array}$ & $\begin{array}{c}0.165 \\
(0.257)\end{array}$ \\
\hline Status self-employed, base employee & $\begin{array}{l}-0.032 \\
(0.076)\end{array}$ & $\begin{array}{l}-0.017 \\
(0.073)\end{array}$ & $\begin{array}{c}0.062 \\
(0.091)\end{array}$ & $\begin{array}{c}0.049 \\
(0.040)\end{array}$ & $\begin{array}{c}0.063 \\
(0.040)\end{array}$ & $\begin{array}{c}0.050 \\
(0.032)\end{array}$ & $\begin{array}{c}0.047 \\
(0.031)\end{array}$ & $\begin{array}{c}0.072^{*} \\
(0.042)\end{array}$ & $\begin{array}{c}0.048 \\
(0.034)\end{array}$ \\
\hline Status unemployed, base employee & $\begin{array}{l}-0.255 \\
(0.179)\end{array}$ & $\begin{array}{c}-0.353^{*} \\
(0.203)\end{array}$ & $\begin{array}{c}-0.524^{* *} \\
(0.255)\end{array}$ & $\begin{array}{c}-0.192^{* *} \\
(0.094)\end{array}$ & $\begin{array}{c}-0.131^{*} \\
(0.070)\end{array}$ & $\begin{array}{l}-0.061 \\
(0.054)\end{array}$ & $\begin{array}{l}-0.054 \\
(0.041)\end{array}$ & $\begin{array}{l}-0.034 \\
(0.032)\end{array}$ & $\begin{array}{c}0.009 \\
(0.026)\end{array}$ \\
\hline Status other inactive, base employee & $\begin{array}{c}0.009 \\
(0.048)\end{array}$ & $\begin{array}{c}0.027 \\
(0.060)\end{array}$ & $\begin{array}{l}-0.046 \\
(0.096)\end{array}$ & $\begin{array}{l}-0.015 \\
(0.036)\end{array}$ & $\begin{array}{l}-0.027 \\
(0.039)\end{array}$ & $\begin{array}{l}-0.027 \\
(0.037)\end{array}$ & $\begin{array}{l}-0.020 \\
(0.028)\end{array}$ & $\begin{array}{l}-0.015 \\
(0.022)\end{array}$ & $\begin{array}{l}-0.003 \\
(0.011)\end{array}$ \\
\hline Status retiree, base employee & $\begin{array}{c}0.450 \\
(0.394)\end{array}$ & $\begin{array}{c}0.183 \\
(0.421)\end{array}$ & $\begin{array}{l}-0.163 \\
(0.626)\end{array}$ & $\begin{array}{l}-0.121 \\
(0.281)\end{array}$ & $\begin{array}{c}0.039 \\
(0.228)\end{array}$ & $\begin{array}{c}0.020 \\
(0.198)\end{array}$ & $\begin{array}{l}0.439^{* *} \\
(0.186)\end{array}$ & $\begin{array}{l}0.425^{* *} \\
(0.185)\end{array}$ & $\begin{array}{l}0.405^{* *} \\
(0.184)\end{array}$ \\
\hline Time in employment & $\begin{array}{c}1.131 \\
(0.770)\end{array}$ & $\begin{array}{c}0.354 \\
(0.919)\end{array}$ & $\begin{array}{l}-0.042 \\
(1.250)\end{array}$ & $\begin{array}{l}-0.299 \\
(0.499)\end{array}$ & $\begin{array}{l}-0.169 \\
(0.420)\end{array}$ & $\begin{array}{l}-0.054 \\
(0.345)\end{array}$ & $\begin{array}{l}-0.224 \\
(0.281)\end{array}$ & $\begin{array}{c}0.142 \\
(0.261)\end{array}$ & $\begin{array}{c}0.390 \\
(0.247)\end{array}$ \\
\hline Time in employment squared / 100 & $\begin{array}{l}-1.078 \\
(0.665)\end{array}$ & $\begin{array}{l}-0.707 \\
(0.763)\end{array}$ & $\begin{array}{l}-0.436 \\
(1.038)\end{array}$ & $\begin{array}{c}0.011 \\
(0.432)\end{array}$ & $\begin{array}{l}-0.075 \\
(0.370)\end{array}$ & $\begin{array}{l}-0.084 \\
(0.313)\end{array}$ & $\begin{array}{c}0.172 \\
(0.270)\end{array}$ & $\begin{array}{l}-0.197 \\
(0.254)\end{array}$ & $\begin{array}{c}-0.599^{* *} \\
(0.279)\end{array}$ \\
\hline Income, thousand EUR & $\begin{array}{l}-0.114 \\
(0.187)\end{array}$ & $\begin{array}{l}-0.076 \\
(0.141)\end{array}$ & $\begin{array}{c}0.002 \\
(0.105)\end{array}$ & $\begin{array}{c}0.023 \\
(0.053)\end{array}$ & $\begin{array}{c}0.021 \\
(0.046)\end{array}$ & $\begin{array}{c}0.018 \\
(0.038)\end{array}$ & $\begin{array}{c}0.026 \\
(0.046)\end{array}$ & $\begin{array}{c}0.033 \\
(0.057)\end{array}$ & $\begin{array}{c}0.022 \\
(0.045)\end{array}$ \\
\hline Income squared /100 & $\begin{array}{c}0.222 \\
(0.190)\end{array}$ & $\begin{array}{c}0.181 \\
(0.170)\end{array}$ & $\begin{array}{c}0.066 \\
(0.138)\end{array}$ & $\begin{array}{l}-0.012 \\
(0.052)\end{array}$ & $\begin{array}{l}-0.012 \\
(0.041)\end{array}$ & $\begin{array}{c}0.001 \\
(0.033)\end{array}$ & $\begin{array}{l}-0.004 \\
(0.032)\end{array}$ & $\begin{array}{c}-0.011 \\
(0.055)\end{array}$ & $\begin{array}{c}0.033 \\
(0.067)\end{array}$ \\
\hline Secondary education, base primary & $\begin{array}{l}-0.410 \\
(0.328)\end{array}$ & $\begin{array}{l}-0.462 \\
(0.368)\end{array}$ & $\begin{array}{c}0.439 \\
(0.460)\end{array}$ & $\begin{array}{c}0.222 \\
(0.180)\end{array}$ & $\begin{array}{c}0.104 \\
(0.135)\end{array}$ & $\begin{array}{l}0.206^{*} \\
(0.106)\end{array}$ & $\begin{array}{c}0.107 \\
(0.090)\end{array}$ & $\begin{array}{c}0.052 \\
(0.079)\end{array}$ & $\begin{array}{l}-0.020 \\
(0.068)\end{array}$ \\
\hline Tertiary education, base primary & $\begin{array}{c}0.547 \\
(0.403)\end{array}$ & $\begin{array}{c}0.683 \\
(0.442)\end{array}$ & $\begin{array}{l}-0.105 \\
(0.575)\end{array}$ & $\begin{array}{l}-0.248 \\
(0.225)\end{array}$ & $\begin{array}{l}-0.211 \\
(0.178)\end{array}$ & $\begin{array}{c}-0.369^{* *} \\
(0.155)\end{array}$ & $\begin{array}{c}-0.322^{* *} \\
(0.138)\end{array}$ & $\begin{array}{l}-0.160 \\
(0.127)\end{array}$ & $\begin{array}{c}0.012 \\
(0.104)\end{array}$ \\
\hline Training in education, base general programmes & $\begin{array}{c}0.269 \\
(0.547)\end{array}$ & $\begin{array}{c}0.129 \\
(0.501)\end{array}$ & $\begin{array}{c}0.219 \\
(0.569)\end{array}$ & $\begin{array}{c}0.130 \\
(0.212)\end{array}$ & $\begin{array}{c}0.074 \\
(0.160)\end{array}$ & $\begin{array}{c}0.061 \\
(0.142)\end{array}$ & $\begin{array}{l}-0.027 \\
(0.116)\end{array}$ & $\begin{array}{l}-0.134 \\
(0.136)\end{array}$ & $\begin{array}{c}0.012 \\
(0.090)\end{array}$ \\
\hline Training in humanities, base general programmes & $\begin{array}{c}0.167 \\
(0.221)\end{array}$ & $\begin{array}{c}0.240 \\
(0.259)\end{array}$ & $\begin{array}{c}0.304 \\
(0.278)\end{array}$ & $\begin{array}{c}0.115 \\
(0.107)\end{array}$ & $\begin{array}{c}0.080 \\
(0.091)\end{array}$ & $\begin{array}{c}0.140^{*} \\
(0.076)\end{array}$ & $\begin{array}{c}0.102 \\
(0.068)\end{array}$ & $\begin{array}{c}0.038 \\
(0.070)\end{array}$ & $\begin{array}{c}0.025 \\
(0.071)\end{array}$ \\
\hline Training in social sciences, base general programmes & $\begin{array}{l}-0.190 \\
(0.353)\end{array}$ & $\begin{array}{c}-0.705^{*} \\
(0.393)\end{array}$ & $\begin{array}{l}-0.116 \\
(0.658)\end{array}$ & $\begin{array}{l}-0.049 \\
(0.252)\end{array}$ & $\begin{array}{l}-0.050 \\
(0.202)\end{array}$ & $\begin{array}{c}0.124 \\
(0.161)\end{array}$ & $\begin{array}{c}0.193 \\
(0.132)\end{array}$ & $\begin{array}{c}0.142 \\
(0.124)\end{array}$ & $\begin{array}{c}0.066 \\
(0.083)\end{array}$ \\
\hline Training in science, base general programmes & $\begin{array}{c}0.024 \\
(0.053)\end{array}$ & $\begin{array}{c}0.014 \\
(0.048)\end{array}$ & $\begin{array}{c}0.024 \\
(0.062)\end{array}$ & $\begin{array}{c}0.012 \\
(0.027)\end{array}$ & $\begin{array}{l}-0.003 \\
(0.018)\end{array}$ & $\begin{array}{l}-0.006 \\
(0.016)\end{array}$ & $\begin{array}{l}-0.005 \\
(0.013)\end{array}$ & $\begin{array}{l}-0.005 \\
(0.013)\end{array}$ & $\begin{array}{l}-0.004 \\
(0.010)\end{array}$ \\
\hline Training in engineering, base general programmes & $\begin{array}{l}0.602^{* *} \\
(0.268)\end{array}$ & $\begin{array}{c}0.919^{* * * *} \\
(0.314)\end{array}$ & $\begin{array}{l}0.681^{*} \\
(0.388)\end{array}$ & $\begin{array}{c}0.134 \\
(0.147)\end{array}$ & $\begin{array}{c}0.080 \\
(0.116)\end{array}$ & $\begin{array}{c}0.021 \\
(0.096)\end{array}$ & $\begin{array}{c}0.046 \\
(0.085)\end{array}$ & $\begin{array}{c}0.084 \\
(0.084)\end{array}$ & $\begin{array}{c}0.019 \\
(0.070)\end{array}$ \\
\hline
\end{tabular}


Training in agriculture, base general programmes

Training in health, base general programmes

Training in services, base general programmes

Age

Age squared / 100

Immigrant, base born in Estonia

One child, base no children

Two children, base no children

Three children, base no children

Child under three years, base other

Marital status widow, base single/never married

Marital status divorced, base single/never married

Marital status married, base single/never married

Marital status cohabiting, base single/never married

Region north, base central Estonia

Region west, base central Estonia

Region south, base central Estonia

Region east, base central Estonia

Other town, base capital town

Village, base capital town

\begin{tabular}{|c|c|c|c|c|c|c|c|c|}
\hline 0.023 & -0.034 & -0.042 & -0.017 & -0.031 & 0.010 & 0.013 & -0.013 & -0.032 \\
\hline$(0.081)$ & $(0.084)$ & $(0.096)$ & $(0.038)$ & $(0.034)$ & $(0.032)$ & $(0.029)$ & $(0.033)$ & $(0.036)$ \\
\hline-0.313 & $-0.451^{* *}$ & $-0.746^{* * * *}$ & $-0.233^{* *}$ & $-0.192^{* *}$ & 0.172 & 0.131 & 0.125 & -0.021 \\
\hline (0.192) & $(0.196)$ & $(0.264)$ & $(0.098)$ & $(0.082)$ & $(0.150)$ & $(0.149)$ & $(0.124)$ & $(0.107)$ \\
\hline 0.074 & 0.153 & 0.067 & -0.016 & -0.020 & -0.031 & -0.009 & 0.019 & 0.012 \\
\hline (0.069) & $(0.104)$ & $(0.102)$ & $(0.041)$ & $(0.034)$ & $(0.031)$ & $(0.024)$ & $(0.025)$ & $(0.024)$ \\
\hline-1.126 & -0.453 & -5.029 & -2.478 & $-2.713^{* * *}$ & $-2.905^{* * * *}$ & -0.708 & -0.945 & -0.077 \\
\hline (2.339) & $(2.793)$ & (4.097) & (1.624) & (1.329) & (1.073) & $(0.829)$ & $(0.792)$ & $(0.686)$ \\
\hline-0.586 & -1.122 & 3.598 & 2.222 & 2.301 & $2.542^{* *}$ & -0.016 & 0.405 & -0.166 \\
\hline (2.258) & $(2.641)$ & $(4.143)$ & $(1.723)$ & (1.408) & $(1.154)$ & $(0.936)$ & $(0.894)$ & $(0.817)$ \\
\hline-0.145 & $-0.236^{*}$ & -0.122 & 0.036 & 0.021 & -0.003 & -0.034 & -0.007 & -0.019 \\
\hline$(0.126)$ & $(0.143)$ & $(0.180)$ & $(0.074)$ & $(0.063)$ & $(0.052)$ & $(0.048)$ & $(0.044)$ & $(0.043)$ \\
\hline 0.010 & -0.028 & -0.031 & -0.007 & -0.007 & 0.012 & 0.006 & 0.008 & -0.002 \\
\hline$(0.046)$ & $(0.062)$ & $(0.074)$ & $(0.026)$ & $(0.022)$ & $(0.024)$ & $(0.016)$ & $(0.018)$ & $(0.012)$ \\
\hline 0.039 & -0.027 & 0.009 & 0.010 & 0.025 & 0.028 & 0.020 & 0.018 & -0.005 \\
\hline (0.057) & $(0.055)$ & $(0.067)$ & $(0.027)$ & $(0.030)$ & $(0.030)$ & $(0.024)$ & $(0.023)$ & $(0.019)$ \\
\hline-0.077 & -0.139 & -0.068 & -0.021 & -0.020 & 0.010 & -0.012 & -0.019 & -0.006 \\
\hline (0.067) & $(0.110)$ & $(0.087)$ & $(0.032)$ & $(0.028)$ & $(0.023)$ & $(0.021)$ & $(0.025)$ & $(0.017)$ \\
\hline-0.015 & 0.045 & 0.084 & 0.017 & -0.005 & -0.009 & 0.013 & 0.015 & 0.008 \\
\hline$(0.050)$ & $(0.071)$ & $(0.104)$ & $(0.032)$ & $(0.023)$ & $(0.022)$ & $(0.022)$ & $(0.020)$ & $(0.016)$ \\
\hline 0.719 & $2.234^{* * * *}$ & 1.553 & 0.528 & 0.136 & 0.085 & 0.114 & 0.048 & 0.116 \\
\hline$(0.771)$ & $(0.841)$ & $(1.028)$ & $(0.436)$ & $(0.348)$ & $(0.288)$ & $(0.231)$ & $(0.208)$ & $(0.150)$ \\
\hline 0.205 & $0.366^{*}$ & 0.277 & 0.052 & 0.011 & -0.035 & -0.011 & -0.040 & -0.046 \\
\hline$(0.202)$ & $(0.214)$ & $(0.226)$ & $(0.079)$ & $(0.062)$ & $(0.052)$ & $(0.041)$ & $(0.042)$ & $(0.037)$ \\
\hline 0.029 & -0.108 & 0.020 & 0.032 & 0.040 & 0.047 & 0.061 & 0.037 & 0.030 \\
\hline (0.094) & $(0.130)$ & $(0.122)$ & $(0.055)$ & $(0.051)$ & $(0.051)$ & $(0.059)$ & $(0.042)$ & $(0.032)$ \\
\hline $0.589^{* * *}$ & -0.164 & 0.148 & 0.065 & 0.087 & 0.065 & 0.087 & 0.060 & -0.005 \\
\hline (0.300) & $(0.336)$ & $(0.469)$ & $(0.182)$ & $(0.132)$ & $(0.096)$ & $(0.076)$ & $(0.068)$ & $(0.044)$ \\
\hline-0.279 & -0.269 & -0.115 & 0.054 & 0.071 & 0.033 & 0.071 & -0.027 & -0.018 \\
\hline$(0.211)$ & $(0.230)$ & $(0.226)$ & $(0.091)$ & $(0.083)$ & $(0.058)$ & $(0.068)$ & $(0.049)$ & $(0.041)$ \\
\hline 0.006 & 0.004 & -0.009 & -0.011 & -0.010 & -0.003 & -0.006 & -0.001 & -0.001 \\
\hline$(0.052)$ & $(0.058)$ & $(0.074)$ & $(0.042)$ & $(0.036)$ & (0.019) & $(0.023)$ & $(0.013)$ & $(0.011)$ \\
\hline 0.096 & 0.129 & 0.074 & -0.007 & -0.027 & -0.002 & -0.043 & 0.002 & -0.002 \\
\hline$(0.130)$ & $(0.154)$ & $(0.149)$ & $(0.055)$ & $(0.050)$ & $(0.036)$ & $(0.047)$ & $(0.030)$ & $(0.022)$ \\
\hline 0.057 & 0.043 & -0.010 & -0.037 & -0.042 & -0.016 & -0.043 & -0.027 & -0.012 \\
\hline (0.104) & $(0.103)$ & $(0.110)$ & $(0.056)$ & $(0.056)$ & $(0.031)$ & $(0.052)$ & $(0.032)$ & $(0.018)$ \\
\hline 0.132 & 0.099 & 0.077 & 0.009 & 0.028 & 0.013 & 0.008 & -0.021 & -0.009 \\
\hline$(0.122)$ & $(0.125)$ & $(0.161)$ & $(0.061)$ & $(0.051)$ & $(0.038)$ & $(0.035)$ & $(0.035)$ & $(0.029)$ \\
\hline 0.040 & 0.031 & 0.039 & 0.012 & 0.012 & 0.008 & 0.009 & 0.003 & 0.003 \\
\hline (0.159) & $(0.131)$ & $(0.167)$ & $(0.055)$ & $(0.053)$ & $(0.037)$ & $(0.038)$ & $(0.021)$ & $(0.021)$ \\
\hline
\end{tabular}




\begin{tabular}{|c|c|c|c|c|c|c|c|c|c|}
\hline \multicolumn{10}{|l|}{ The unexplained gap } \\
\hline Total & $\begin{array}{l}-2.282 \\
(1.509)\end{array}$ & $\begin{array}{l}-1.764 \\
(1.338)\end{array}$ & $\begin{array}{c}-3.514^{* *} \\
(1.610)\end{array}$ & $\begin{array}{l}-0.713 \\
(0.687)\end{array}$ & $\begin{array}{l}-0.599 \\
(0.541)\end{array}$ & $\begin{array}{c}-0.896^{*} \\
(0.462)\end{array}$ & $\begin{array}{c}-0.751^{*} \\
(0.409)\end{array}$ & $\begin{array}{l}-0.285 \\
(0.388)\end{array}$ & $\begin{array}{l}-0.165 \\
(0.268)\end{array}$ \\
\hline \multirow[t]{2}{*}{ Status self-employed, base employee } & -0.192 & $-0.209^{*}$ & 0.047 & 0.042 & 0.056 & 0.045 & 0.032 & 0.049 & -0.006 \\
\hline & $(0.158)$ & $(0.114)$ & $(0.103)$ & $(0.048)$ & $(0.041)$ & $(0.033)$ & $(0.031)$ & $(0.036)$ & $(0.035)$ \\
\hline \multirow[t]{2}{*}{ Status unemployed, base employee } & -0.096 & -0.059 & -0.213 & -0.066 & 0.002 & -0.011 & -0.044 & -0.048 & -0.040 \\
\hline & $(0.308)$ & $(0.227)$ & $(0.193)$ & $(0.083)$ & $(0.058)$ & $(0.047)$ & $(0.040)$ & $(0.037)$ & $(0.037)$ \\
\hline \multirow[t]{2}{*}{ Status other inactive, base employee } & -0.087 & $0.745^{*}$ & -0.125 & 0.224 & 0.004 & -0.104 & -0.044 & -0.042 & -0.055 \\
\hline & $(0.590)$ & $(0.450)$ & $(0.452)$ & $(0.204)$ & $(0.141)$ & $(0.110)$ & $(0.092)$ & $(0.078)$ & $(0.068)$ \\
\hline \multirow[t]{2}{*}{ Status retiree, base employee } & 1.852 & 1.481 & 1.837 & $1.069^{*}$ & 0.552 & 0.190 & $-0.648^{*}$ & $-0.746^{* *}$ & $-0.887^{* * *}$ \\
\hline & $(1.437)$ & $(1.226)$ & $(1.283)$ & $(0.626)$ & $(0.486)$ & $(0.418)$ & $(0.377)$ & $(0.375)$ & $(0.363)$ \\
\hline \multirow{2}{*}{ Time in employment } & -6.625 & $-11.483^{*}$ & -6.047 & 0.057 & 0.979 & -0.367 & 1.203 & -0.440 & -1.670 \\
\hline & $(6.181)$ & $(6.530)$ & $(6.658)$ & $(2.928)$ & $(2.346)$ & $(1.915)$ & $(1.580)$ & $(1.485)$ & $(1.394)$ \\
\hline \multirow[t]{2}{*}{ Time in employment squared / 100} & 2.997 & 6.542 & 4.928 & 0.773 & -0.022 & 0.435 & -0.857 & 0.304 & $2.000^{*}$ \\
\hline & $(3.983)$ & $(4.004)$ & $(4.237)$ & $(1.951)$ & $(1.585)$ & $(1.326)$ & $(1.144)$ & $(1.084)$ & $(1.098)$ \\
\hline \multirow[t]{2}{*}{ Income, thousand EUR } & $-3.684^{* * *}$ & $-2.537^{*}$ & -1.316 & -0.468 & -0.028 & 0.255 & 0.294 & 0.217 & 0.236 \\
\hline & $(1.629)$ & $(1.319)$ & $(1.344)$ & $(0.622)$ & $(0.475)$ & $(0.384)$ & $(0.339)$ & $(0.387)$ & $(0.388)$ \\
\hline \multirow[t]{2}{*}{ Income squared /100 } & $0.778^{* * *}$ & $0.628^{* * *}$ & 0.336 & 0.058 & -0.014 & -0.023 & -0.020 & -0.023 & 0.053 \\
\hline & $(0.334)$ & $(0.307)$ & $(0.327)$ & $(0.140)$ & $(0.108)$ & $(0.089)$ & $(0.079)$ & $(0.131)$ & $(0.151)$ \\
\hline \multirow[t]{2}{*}{ Secondary education, base primary } & 0.780 & -1.670 & 0.279 & -0.476 & -0.457 & 0.132 & -0.104 & 0.090 & -0.239 \\
\hline & $(1.481)$ & $(1.317)$ & $(1.276)$ & $(0.561)$ & $(0.411)$ & $(0.312)$ & $(0.274)$ & $(0.243)$ & $(0.199)$ \\
\hline \multirow[t]{2}{*}{ Tertiary education, base primary } & -1.844 & $-4.131^{* * *}$ & -1.669 & -0.871 & -0.393 & 0.127 & 0.159 & 0.148 & -0.295 \\
\hline & $(1.803)$ & $(1.507)$ & $(1.488)$ & $(0.647)$ & $(0.488)$ & $(0.398)$ & $(0.353)$ & $(0.340)$ & $(0.289)$ \\
\hline \multirow[t]{2}{*}{ Training in education, base general programmes } & -0.041 & 0.168 & -0.093 & -0.058 & -0.077 & -0.065 & 0.055 & 0.157 & 0.031 \\
\hline & $(0.654)$ & $(0.583)$ & $(0.633)$ & $(0.242)$ & $(0.183)$ & $(0.163)$ & $(0.134)$ & $(0.153)$ & $(0.101)$ \\
\hline \multirow[t]{2}{*}{ Training in humanities, base general programmes } & -0.316 & -0.291 & -0.299 & -0.117 & -0.087 & -0.124 & -0.083 & -0.039 & -0.044 \\
\hline & $(0.347)$ & $(0.345)$ & $(0.349)$ & $(0.142)$ & $(0.120)$ & $(0.097)$ & $(0.090)$ & $(0.095)$ & $(0.096)$ \\
\hline \multirow[t]{2}{*}{ Training in social sciences, base general programmes } & 1.353 & $1.913^{* * * *}$ & 0.630 & 0.333 & 0.191 & -0.110 & -0.230 & -0.280 & -0.173 \\
\hline & $(0.920)$ & $(0.732)$ & $(0.971)$ & $(0.394)$ & $(0.307)$ & $(0.245)$ & $(0.200)$ & $(0.190)$ & $(0.137)$ \\
\hline \multirow{2}{*}{ Training in science, base general programmes } & 0.082 & 0.047 & 0.067 & 0.046 & -0.022 & -0.018 & 0.003 & -0.013 & -0.016 \\
\hline & $(0.075)$ & $(0.088)$ & $(0.074)$ & $(0.033)$ & $(0.033)$ & $(0.024)$ & $(0.022)$ & $(0.022)$ & $(0.020)$ \\
\hline \multirow[t]{2}{*}{ Training in engineering, base general programmes } & 0.836 & $1.314^{* * * *}$ & $1.065^{* * * *}$ & $0.405^{* * *}$ & 0.198 & 0.136 & $0.232^{* * *}$ & 0.107 & 0.047 \\
\hline & $(0.621)$ & $(0.457)$ & $(0.404)$ & $(0.183)$ & $(0.135)$ & $(0.113)$ & $(0.103)$ & $(0.098)$ & $(0.078)$ \\
\hline \multirow{2}{*}{ Training in agriculture, base general programmes } & -0.074 & 0.276 & 0.129 & 0.101 & 0.108 & -0.001 & -0.038 & -0.020 & 0.015 \\
\hline & $(0.238)$ & $(0.230)$ & $(0.199)$ & $(0.095)$ & $(0.073)$ & $(0.067)$ & $(0.062)$ & $(0.068)$ & $(0.070)$ \\
\hline \multirow{2}{*}{ Training in health, base general programmes } & $0.874^{* *}$ & $0.864^{* * * *}$ & $0.905^{* * * *}$ & $0.280^{* * *}$ & $0.263^{* * *}$ & -0.159 & -0.127 & -0.183 & -0.006 \\
\hline & $(0.410)$ & $(0.324)$ & $(0.310)$ & $(0.128)$ & $(0.106)$ & $(0.167)$ & $(0.165)$ & $(0.140)$ & $(0.121)$ \\
\hline \multirow[t]{2}{*}{ Training in services, base general programmes } & -0.096 & 0.358 & 0.189 & 0.030 & -0.019 & -0.040 & 0.016 & 0.057 & 0.031 \\
\hline & $(0.360)$ & $(0.256)$ & $(0.223)$ & $(0.106)$ & $(0.079)$ & $(0.067)$ & $(0.060)$ & $(0.057)$ & $(0.054)$ \\
\hline Age & $-47.038^{*}$ & -18.189 & 9.426 & -12.351 & -7.666 & -0.263 & $-9.513^{*}$ & -3.612 & -4.676 \\
\hline
\end{tabular}




\section{Age squared / 100}

Immigrant, base born in Estonia

One child, base no children

Two children, base no children

Three children, base no children

Child under three years, base other

Marital status widow, base single/never married

Marital status divorced, base single/never married

Marital status married, base single/never married

Marital status cohabiting, base single/never married

Region north, base central Estonia

Region west, base central Estonia

Region south, base central Estonia

Region east, base central Estonia

Other town, base capital town

Village, base capital town

\section{Constant}

Source: Authors' calculations from the Estonian HFCS.

Notes: Standard errors in parentheses. ${ }^{*},{ }^{*},{ }^{* * *}$ refer to statistical significance at $10 \%, 5 \%$ and $1 \%$ level.

\begin{tabular}{|c|c|c|c|c|c|c|c|c|}
\hline (26.397) & (24.954) & $(24.820)$ & (10.864) & $(8.251)$ & (6.520) & $(5.342)$ & $(5.058)$ & (4.498) \\
\hline 18.326 & 8.708 & -5.793 & 4.898 & 3.373 & 0.116 & $6.562^{*}$ & 3.253 & 3.107 \\
\hline (13.868) & $(13.581)$ & (14.564) & $(6.602)$ & $(5.082)$ & (4.093) & $(3.451)$ & (3.284) & (3.028) \\
\hline-0.048 & 0.573 & 0.321 & -0.110 & 0.019 & 0.157 & 0.252 & 0.171 & $0.288^{* * *}$ \\
\hline$(0.622)$ & $(0.533)$ & $(0.598)$ & $(0.274)$ & $(0.223)$ & $(0.186)$ & $(0.170)$ & $(0.158)$ & $(0.145)$ \\
\hline 0.507 & $1.433^{* * *}$ & $1.026^{*}$ & $0.441^{*}$ & 0.226 & -0.173 & -0.030 & -0.167 & 0.049 \\
\hline$(0.762)$ & $(0.599)$ & $(0.566)$ & $(0.254)$ & $(0.197)$ & $(0.157)$ & $(0.137)$ & $(0.130)$ & $(0.111)$ \\
\hline 0.313 & $0.639^{* *}$ & 0.119 & 0.021 & -0.105 & -0.092 & -0.048 & -0.074 & 0.029 \\
\hline$(0.381)$ & $(0.315)$ & $(0.283)$ & $(0.124)$ & $(0.096)$ & $(0.081)$ & $(0.072)$ & $(0.072)$ & $(0.072)$ \\
\hline 0.466 & $0.541^{* * *}$ & 0.208 & 0.120 & 0.038 & -0.036 & 0.029 & 0.045 & -0.022 \\
\hline$(0.286)$ & $(0.236)$ & $(0.203)$ & $(0.088)$ & $(0.068)$ & $(0.062)$ & $(0.056)$ & $(0.058)$ & $(0.051)$ \\
\hline$-0.817^{*}$ & -0.561 & $-0.594^{*}$ & $-0.295^{*}$ & -0.094 & -0.032 & -0.131 & $-0.131^{*}$ & -0.051 \\
\hline$(0.484)$ & $(0.391)$ & $(0.348)$ & $(0.153)$ & $(0.113)$ & $(0.098)$ & $(0.090)$ & $(0.077)$ & $(0.067)$ \\
\hline-0.400 & $-2.467^{* *}$ & $-2.202^{*}$ & $-0.955^{*}$ & -0.365 & -0.255 & -0.108 & -0.080 & -0.192 \\
\hline (1.305) & (1.194) & $(1.261)$ & $(0.567)$ & $(0.440)$ & $(0.366)$ & $(0.301)$ & $(0.270)$ & $(0.208)$ \\
\hline 0.504 & -0.722 & -0.820 & -0.330 & -0.191 & -0.034 & -0.112 & 0.060 & 0.088 \\
\hline$(0.817)$ & $(0.621)$ & $(0.573)$ & $(0.242)$ & $(0.184)$ & $(0.152)$ & $(0.131)$ & $(0.124)$ & $(0.108)$ \\
\hline 2.584 & -1.453 & -0.201 & 0.106 & 0.360 & 0.486 & $0.622^{* * *}$ & 0.352 & 0.255 \\
\hline (1.714) & $(1.262)$ & (1.137) & $(0.505)$ & $(0.374)$ & $(0.309)$ & $(0.273)$ & $(0.261)$ & $(0.204)$ \\
\hline 1.202 & -0.253 & 0.298 & 0.084 & 0.028 & 0.043 & 0.053 & 0.047 & -0.008 \\
\hline$(0.802)$ & $(0.567)$ & $(0.501)$ & $(0.218)$ & $(0.149)$ & $(0.114)$ & $(0.093)$ & $(0.085)$ & $(0.065)$ \\
\hline 2.428 & 1.462 & 0.263 & -1.227 & $-1.341^{*}$ & $-1.211^{* * *}$ & $-1.875^{* * * *}$ & $-0.759^{*}$ & -0.068 \\
\hline$(2.406)$ & $(2.013)$ & (1.991) & $(0.907)$ & $(0.696)$ & $(0.537)$ & $(0.528)$ & $(0.440)$ & $(0.369)$ \\
\hline 0.501 & 0.399 & -0.178 & -0.256 & $-0.236^{*}$ & -0.137 & -0.172 & -0.093 & -0.037 \\
\hline$(0.506)$ & $(0.432)$ & $(0.413)$ & $(0.186)$ & $(0.143)$ & $(0.110)$ & $(0.105)$ & $(0.080)$ & $(0.066)$ \\
\hline 1.205 & $1.623^{*}$ & 0.538 & 0.010 & -0.155 & -0.019 & -0.366 & -0.136 & -0.047 \\
\hline (1.091) & $(0.943)$ & $(0.843)$ & $(0.387)$ & $(0.295)$ & $(0.233)$ & $(0.224)$ & $(0.180)$ & $(0.142)$ \\
\hline 1.239 & 0.915 & 0.230 & -0.096 & -0.154 & -0.097 & -0.232 & -0.157 & -0.073 \\
\hline$(0.776)$ & $(0.618)$ & $(0.575)$ & $(0.249)$ & $(0.191)$ & $(0.153)$ & $(0.141)$ & $(0.097)$ & $(0.076)$ \\
\hline-0.268 & -0.677 & -0.084 & -0.531 & -0.316 & -0.269 & -0.326 & $-0.518^{* *}$ & -0.052 \\
\hline (1.349) & $(1.057)$ & (1.112) & $(0.486)$ & $(0.363)$ & $(0.288)$ & $(0.272)$ & $(0.259)$ & $(0.218)$ \\
\hline 1.153 & 1.051 & $1.799^{*}$ & 0.384 & 0.383 & 0.096 & 0.057 & -0.086 & 0.248 \\
\hline (1.147) & $(0.911)$ & $(0.977)$ & $(0.445)$ & $(0.344)$ & $(0.268)$ & $(0.259)$ & $(0.257)$ & $(0.228)$ \\
\hline 19.367 & 11.258 & -8.520 & $8.013^{*}$ & 4.360 & 0.527 & $4.787^{* * *}$ & 2.302 & 2.013 \\
\hline (14.293) & $(11.422)$ & $(10.470)$ & $(4.591)$ & (3.296) & $(2.522)$ & $(2.125)$ & $(2.017)$ & (1.733) \\
\hline 1208 & 1208 & 1208 & 1208 & 1208 & 1208 & 1208 & 1208 & 1208 \\
\hline
\end{tabular}

1208
1208
1208 